\title{
The characteristics and performance of hybrid redox flow batteries with zinc negative electrodes for energy storage
}

\author{
Luis F. Arenas, ${ }^{\mathrm{a}}$ Adeline Loh, ${ }^{\mathrm{b}}$ David P. Trudgeon, ${ }^{\mathrm{b}}$ Xiaohong Li, ${ }^{\mathrm{b}}$ \\ Carlos Ponce de León, ${ }^{a}$ Frank C. Walsh ${ }^{\text {a* }}$ \\ a. Electrochemical Engineering Laboratory, Energy Technology Group, Department of \\ Mechanical Engineering, University of Southampton, SO17 1BJ, UK. \\ b. Renewable Energy Group, College of Engineering, Mathematics and Physical Sciences, \\ University of Exeter, Penryn Campus, Cornwall TR10 9FE, UK. \\ * Author for correspondence, f.c.walsh@soton.ac.uk
}

\begin{abstract}
Zinc negative electrodes are well known in primary batteries based on the classical Leclanché cell but a more recent development is the introduction of a number of rechargeable redox flow batteries for pilot and commercial scale using a zinc/zinc ion redox couple, in acid or alkaline electrolytes, or transformation of surface zinc oxides as a reversible electrode. The benefits and limitations of zinc negative electrodes are outlined with examples to discuss their thermodynamic and kinetic characteristics along with their practical aspects. Four main types of redox flow batteries employing zinc electrodes are considered, the zinc-bromine, zinccerium, zinc-air and zinc-nickel. Problems associated with zinc deposition and dissolution, especially in acid media, are summarised. The main features of each battery are identified and the benefits of a flowing electrolyte are explained. In each case, a summary of their development, including the electrode and cell reactions, their potentials, the performance of the positive and negative electrodes, the benefits of a single flow compartment and cell developments for energy storage are included. Remaining challenges are highlighted and possibilities for future advances in redox flow batteries are suggested.
\end{abstract}

Keywords: air electrode; bromine; cerium; energy storage; nickel; redox flow battery. 


\section{Contents}

1. Introduction

1.1 Energy storage and sustainability

1.2 Zinc-based redox flow batteries

2. Zinc-bromine redox flow batteries

2.1 The zinc negative electrode

2.2 The bromine positive electrode

2.3 Cell performance

2.4 Prospects for zinc-bromine redox flow batteries

3. Zinc-cerium redox flow batteries

3.1 The zinc negative electrode

3.2 The cerium positive electrode

3.3 Cell performance

3.4 Prospects for zinc-cerium redox flow batteries

4. Zinc-air redox flow batteries

4.1 The zinc negative electrode

4.2 The oxygen positive electrode

4.3 Cell developments

4.4 Prospects for zinc-air redox flow batteries

5. Zinc-nickel redox flow batteries

5.1 The zinc negative electrode

5.2 The nickel positive electrode

5.3 Cell developments

5.4 Prospects for zinc-nickel redox flow batteries

6. Other zinc-based redox flow batteries

7. New trends on zinc-based redox flow batteries

7.1 Zinc polymer electrodes

7.2 Ionic liquid electrolytes

8. Conclusions

9. Topics requiring further research

(Approx. text 16,600 words, 13 equations/reactions, 5 tables, 17 figures and 291 references).

Note: The published version contains several minor corrections. 
The characteristics and performance of redox flow batteries with zinc negative electrodes for energy storage

\section{Highlights}

- The importance of $\mathrm{Zn}$ negative electrodes for RFBs is highlighted.

- Acidic, neutral and alkaline electrolytes are involved.

- $\quad \mathrm{Zn}-\mathrm{Br}_{2}, \mathrm{Zn}$-air, $\mathrm{Zn}-\mathrm{Ce}, \mathrm{Zn}-\mathrm{Ni}$ and other $\mathrm{Zn}$-based cells are featured.

- Electrode potentials and charge-discharge performance are considered.

- Developments are critically discussed; further R \& D needs are underlined.

\section{Graphical abstract}

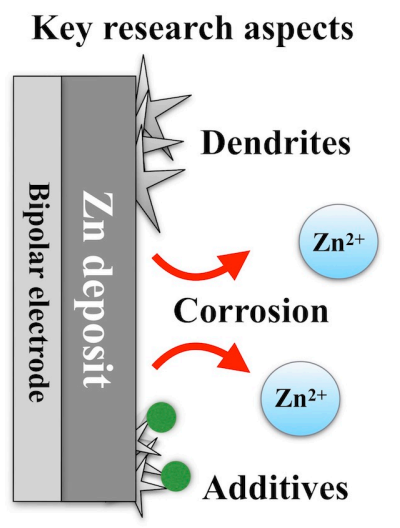

Zn deposition/stripping

Hybrid redox flow batteries

$E^{\theta}=-0.76 \mathrm{~V}$ vs. SHE
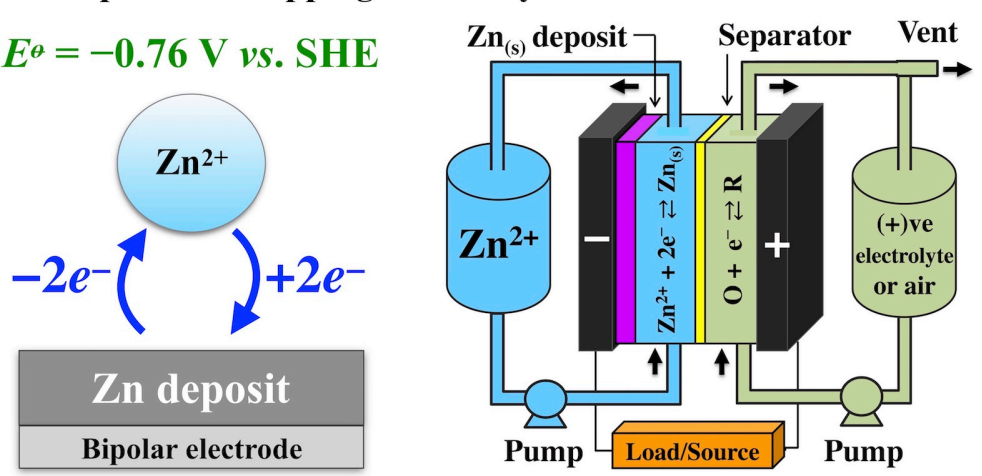


\section{Introduction}

\subsection{Energy storage and sustainability}

The need for renewable energy arises from the realisation that fossil fuel supplies are being rapidly depleted with adverse environmental impacts, coupled with the ever-increasing growth of energy consumption due to the growing global population and the demand for higher standards of living $[1,2]$. Renewable energy can be produced through several means solar, wind, hydro, tidal, geothermal and biomass. The integration of these carbon-free technologies into the electric grid contributes towards a safe, reliable, flexible, affordable and sustainable energy supply which is essential for the continuous development of a modern society [3]. Several countries have recognised the importance of this such as the European Commission who initiated a Renewable Energy Directive for 2020 [4] proposing that 20\% of energy consumption in the EU should be derived from renewable sources. This has now been further supplemented by a proposal published in 2016 for the share of energy consumption by renewables to be increased to $27 \%$ by 2030 [5]. Likewise, China's National Energy Administration (NEA) has set an ambitious target for $50 \%$ of energy consumption in China to be generated by renewable sources by 2020 [6].

In spite of this, the generation of energy from renewable sources is problematic as energy produced is usually in the form of secondary energy [7] making matching energy supply to demand a complex issue. An Energy Storage System (ESS) is recommended as a viable solution to the intermittency of renewable energy generation [8-10] and seasonal consumer demand as it absorbs the surplus generation capacity, smooths residual loads and provides flexibility for energy balance [11]. There are several ESS technologies which are near to, or currently, commercially available such as pumped-hydro, compressed air, flywheel and rechargeable battery systems. These systems have been reviewed [12-17] in detail based on 
their technical, economic and environmental features to give a good indication of their relevance to different applications.

In general, the generation of energy from renewable sources is carried out on a much smaller scale than conventional power plants, commonly in the range of kilowatts to megawatts, with various levels of applications ranging from small off-grid communities to grid-scale storage [18]. These requirements are suitably met by redox flow batteries (RFBs), first developed by NASA in the 1970s [19] as an electrical-energy storage technology. RFBs have proven to be able to support the transmission and distribution of renewable energy efficiently within the grid due to their high cycling efficiency, reasonable nominal duration, reliable long lifespan and flexibility in terms of geographical location [20]. In addition to renewable energy applications, RFBs are also suited to frequency response and UPS services, due to their fast response time, in the order of seconds [7, 17]. Other advantages of RFBs, which include their ability to operate at ambient temperature and pressure, absence of harmful emissions, safety in comparison to lithium-ion batteries and greater efficiency in comparison to electrolysis cells, make them ideal medium to large-scale energy storage solutions [21].

\subsection{Zinc-based redox flow batteries}

Recently, the $\mathrm{Zn}(\mathrm{II}) / \mathrm{Zn}$ redox couple has received considerable interest as the negative electrode reaction in several redox flow batteries (RFBs) for renewable energy storage. Some of the advantages of using this redox couple include: a negative standard electrode, the high solubility of $\mathrm{Zn}(\mathrm{II})$ ions, fast kinetics as well as the low cost, abundance and recyclability of zinc compounds. Depending on the chemistry of the RFB, the electrodeposition and redissolution reaction can take place either in acid or in alkaline media [22], respectively: 


$$
\begin{array}{cc}
\mathrm{Zn}^{2+}+2 \mathrm{e}^{-} \underset{\text { Discharge }}{\stackrel{\text { Charge }}{\rightleftarrows}} \mathrm{Zn}_{(\mathrm{s})} & E^{0}=-0.76 \mathrm{~V} \text { vs. SHE } \\
\mathrm{Zn}(\mathrm{OH})_{4}^{2-}+2 \mathrm{e}^{-} \underset{\text { Discharge }}{\stackrel{\text { Charge }}{\rightleftarrows}} \mathrm{Zn}+4 \mathrm{OH}^{-} & E^{0}=-1.25 \text { V vs. SHE }
\end{array}
$$

The standard potentials of common positive electrode reactions and parasitic reactions in zinc RFBs are given in Table 1. It can be seen that numerous RFB chemistries are possible with acid and alkaline electrolytes, as shown in Table 2. In general, high cell potentials are achieved by these systems compared to other proposed RFBs. Thermodynamically, the main competing reaction is $\mathrm{H}_{2}$ evolution at the $\mathrm{Zn}$ electrode, and thus high coulombic efficiencies are only attainable by inhibiting this process. $\mathrm{H}_{2}$ evolution must also be avoided during open-circuit, as it can result in self-discharge via proton reduction.

As shown in Figure 1, several RFBs have taken advantage of these properties, exhibiting the highest cell potentials among aqueous systems, which are least $400 \mathrm{mV}$ higher than the all vanadium cell in most cases. Yet, Zn-based RFBs compromise with relative low charging efficiency, difficult uniform zinc electrodeposition and some degree of self-discharge [28]. The controlled electrodeposition of $\mathrm{Zn}$ is critical to produce compact, dendrite-free deposits, uniformly coating the negative side of the bipolar electrodes, in order to prevent shortcircuiting. Similarly, uniform and efficient redissolution of the metallic deposit is necessary to avoid its accumulation over repeated battery cycling.

A timeline of developments in rechargeable zinc batteries is presented in Figure 2. These cells have a long history and, in some cases, have achieved high reliability, e.g., classical Leclanché's zinc/carbon cells [42, 43]. Nickel/zinc and zinc/air and batteries are also wellknown. In the field of RFBs, the zinc-bromine system is the most researched and 
commercialised, having almost 40 years of development [44]. In contrast, zinc-air and zinccerium RFBs continue under investigation, while zinc-nickel RFB has the potential to be developed into economic, undivided cells. Recent years have witnessed a diversity of new chemistries, such as zinc-iron or zinc-polyiodide.

A summary of the typical performance of selected Zn-based is shown in Table 3 . It is unfortunate that some authors have presented performance data without explicitly stating the state of charge of the cell or normalized electrolyte flow rates. High cell voltages are predicted for the divided and undivided Zn-Ce systems; the undivided cell has higher efficiencies but the surface area ratios of the positive and negative electrodes need tailoring to prevent selfdischarge. Other cells using air, nickel, bromine or ferricyanide have been reported; although high-energy efficiencies can be achieved at low current densities, the efficiency falls of at a higher operational current density. In electrochemical flow reactors such as RFBs, there are complex relationships among their performance, electrode kinetics, electrolyte flow and operational conditions, as shown in Figure 3 and illustrated by examples in this review. In contrast to static batteries, where electrode and electrolyte composition are the main factors that determine cell potential and current, Zn-based RFBs are governed by flow regime, deposit uniformity and deposit stability. Electrode geometry and electrolyte additives to control the morphology of zinc deposits are critical to cycling life. Thermal management of RFBs of considerable size is also required and it is usually achieved by taking advantage of electrolyte flow through a heat exchanger.

Figure 4 describes some of the most common Zn-based RFBs. All of them have Zn negative electrodes but different positive reactions, some of which take place via phase changes, e.g., at gas diffusion electrodes (GDEs). Diverse separators are employed in view of the $\mathrm{pH}$ and 
composition of the electrolytes, e.g., the $\mathrm{Zn}-\mathrm{Br}_{2}$ has a microporous separator, the $\mathrm{Zn}$-air an anionic membrane, the $\mathrm{Zn}-\mathrm{Ce}$ a cationic membrane and the $\mathrm{Zn}-\mathrm{Ni}$ cell can be undivided.

During R \& D and the scale-up of practical RFBs, several design choices are undertaken. Such decisions will determine the cost, ease of manufacture, efficiency, cycling life and the overall feasibility of the electrochemical energy storage system. Based on the current state of the art and new trends in zinc-based RFBs, Figure 5 illustrates some of the available options for electrode geometry, flow cell configuration, electrolyte composition, zinc electrode substrate and type positive electrode reaction. As explained in the following sections, planar electrodes are traditional to encourage uniform $\mathrm{Zn}$ deposition but research has considered the possible implementation of 3-D electrodes. Most RFBs are divided, although undivided cells significantly reduce cost and complexity. New electrolyte types recently considered, include slurries, emulsions, ionic liquids and deep eutectics.

\section{Zinc-bromine redox flow batteries}

The $\mathrm{Zn}-\mathrm{Br}_{2} \mathrm{RFB}$ is a relatively mature commercial technology and one of the most accessible RFBs, in contrast to the more expensive all vanadium system. The $\mathrm{Zn}-\mathrm{Br}_{2}$ battery is capable of rapid discharge, full depth discharge and high energy storage capacity [52]. The cell was developed with low cost in mind and is not constrained by reagent supply, in contrast to vanadium systems. Its thermodynamic cell potential, $E_{\text {cell }}$, is $1.82 \mathrm{~V}$ and its specific energy is $440 \mathrm{~W} \mathrm{~h} \mathrm{~kg}^{-1}(\mathrm{Zn})$ at $298 \mathrm{~K}$.

The $\mathrm{Zn}-\mathrm{Br}_{2}$ RFB was initially developed in the late 1970s in USA by Gould Inc. [62] and Exxon [63] (although there are patents for static bromide cells dating back to 1885 [46]) and constituted an improvement over the now obsolete and less safe $\mathrm{Zn}-\mathrm{Cl}_{2}$ chemistry. 
Development continued over the next decade under the direction of Sandia National Laboratories [29], including subcontracted work in Energy Research Corp. [64] and Johnson Controls Inc. [65]. Parallel development took place in Japan by Meidensha Electric Co. [66] and in Austria by SEA GmbH [52]. In the late 80s, Toyota Motor Co. demonstrated an electric concept vehicle [52]. A final report for the Sandia developments was published in 1999 [67]. Commercial interest has been renewed since 2010. Currently, major producers include Redflow Ltd., based in Australia, and EnSync Energy Systems in the USA, followed by Zbest Power Co. Ltd. (China), Lotte Chemical Corp. (Korea) and Primus Power (USA).

During charge, a thin layer of metallic zinc is electrodeposited at the carbon-based negative electrode with the simultaneous oxidation of bromide ions to bromine at the positive electrode, as shown in Figure 4a). During discharge, the battery relies on the inverse reactions. The negative electrode reaction shown in reaction (1) is accompanied at the positive electrode by:

$$
\mathrm{Br}_{2 \text { (aq.) }}+2 \mathrm{e}^{-} \underset{\text { Charge }}{\rightleftarrows} 2 \mathrm{Br}^{-} \quad E^{o}=1.06 \mathrm{~V} \text { vs. SHE }
$$

The overall cell reaction is:

$$
\mathrm{Br}_{2 \text { (aq.) }}+\mathrm{Zn} \underset{\text { Charge }}{\stackrel{\text { Discharge }}{\rightleftarrows}} 2 \mathrm{Br}^{-}+\mathrm{Zn}^{2+} \quad E_{\text {cell }}^{o}=1.82 \mathrm{~V}
$$

At the positive electrode, the $\mathrm{Zn}-\mathrm{Br}_{2}$ battery generates $\mathrm{Br}_{2}$, a strongly corrosive halide, during charge. In order to ensure that only a very small fraction of $\mathrm{Br}_{2}$ is free, the electrolyte 
composition includes relatively large quantities of complexing agents. $\mathrm{Br}_{2}$ is present as a Nmethyl-N-ethylmorpholinium (MEM) bromide complex [52], which forms a quaternary ammonium polybromide fused salt [68]. Alternative/joint complexing agents include Nmethyl-ethyl-pyrrolidinium (MEP) [69] or dimethylethylpropylammonium [70] and polydiallyldimethyl-ammonium [71]. The positive electrolyte then forms a two-phase system, the aqueous containing at least three bromine polyhalide complexes in equilibrium and the second, fused bromine salts [68] which precipitate at the bottom of the electrolyte reservoir. Research continues on the development of more stable quaternary ammonium salts as complexing agents, as in the work by Bryans et al. [72]. In addition to potential measurements, the SOC can be monitored by determining the concentration of $\mathrm{ZnBr}_{2}$ in the negative electrolyte via Raman spectroscopy [73].

Although relatively dense, the resulting electrolyte is conductive and chemically stable [68]. This approach has proven to be reliable and safe, in contrast to the complex, expensive and dangerous management of $\mathrm{Cl}_{2}$ hydrates in the $\mathrm{Zn}-\mathrm{Cl}_{2} \mathrm{RFB}$ [74]. Hermetically sealed flow systems for holding $\mathrm{Br}_{2}$ gas would be highly impractical, while a proposed alternative using resorcinol-formaldehyde aqueous cryogel electrodes suffers from the difficulty of its manufacturing process [75]. Both negative and positive electrolytes use the same $\mathrm{Zn}-\mathrm{Br}_{2}$ support electrolyte, easing the problematic cross-mixing common in some RFBs.

Suitable mixtures of the quaternary ammonium complexes can help to prevent the solidification of the fused bromine-complex salt [76]. Quaternary ammonium compounds tend to inhibit the reaction rate [77], although this does not affect the practicality of the cell. It has been shown that polyoxyethylene (20) sorbitan monolaurate can improve the efficiency 
of a $\mathrm{Zn}-\mathrm{Br}_{2}$ cell by forming an emulsion between the phase containing the bromine-complex and the aqueous phase [78]. Recent contributions in the $\mathrm{Zn}-\mathrm{Br}$ system have considered the common bromine sequestering agents as ionic liquid salts. Alternative bromine complexing agents have been suggested [79] and structural variations of the common bromine sequestering agents, tetraalkylammonium bromide and 1-alkyl-1-methylpyrrolidinium bromide, have been studied electrochemically [80]. Five ionic liquid complexing agents were studied by Rajarathnam et al. [81] using electrochemical methods. Three of these compounds showed a better electrochemical performance at a bipolar carbon electrode material, particularly 1-ethylpyridinium bromide. These authors also characterised the $\mathrm{Zn}$ deposits using SEM and XRD.

More expensive and toxic non-aqueous organic solvents have been investigated in the past, including acetonitrile [82] and propionitrile [83, 84]. More recently, nitrobenzene has been studied as a possible supporting electrolyte for a modified $\mathrm{Br}_{2}$-nitrobenzene $\mathrm{RFB}$ [85]. The electrode kinetics of the $\mathrm{B}_{2} / \mathrm{Br}^{-}$redox couple are slow in this media, making expensive $\mathrm{Pt}$ electrodes more suitable. Alternative supporting electrolytes have been considered. Rajarathnam et al. [86] have studied the effect of $0.5 \mathrm{~mol} \mathrm{dm}{ }^{-3} \mathrm{Br}-, \mathrm{SO}_{4}^{-}, \mathrm{H}_{2} \mathrm{PO}_{4}^{-}$and $\mathrm{NO}_{3}^{-}$ anions on the electrode kinetics of the $\mathrm{Br}^{-} / \mathrm{Br}_{2}$ reaction. As shown in Figure 6, these supporting electrolytes resulted in different deposit morphologies. The overall performance was comparable to the classical $\mathrm{NaCl}$ electrolyte. The authors noted that grain refinement was correlated to faster kinetics and that mossy deposits did not necessarily resulted in poor performance in the evaluated conditions. Wu et al. [87] have reported that a $2 \mathrm{~mol} \mathrm{dm}^{-3} \mathrm{NH}_{4} \mathrm{Cl}$ supporting electrolyte significantly decreased cell resistivity while enhancing energy efficiency compared to $\mathrm{KCl}$ electrolytes. The interactions of $\mathrm{NH}_{4}{ }^{+}$ions with bromine complexing agents and its effects on $\mathrm{Zn}$ electrodeposition have not yet been studied. 
Regarding the choice of separator, low cost, non-selective, microporous separators are common, such as porous polyethylene (e.g., Daramic $\left.{ }^{\mathrm{TM}}\right)[64,65,88]$ and acetone-based polymers [89]. The main function of the separator is to avoid bromine diffusion to the $\mathrm{Zn}$ electrode, as this causes self-discharge of the battery. In the worst case, at $40{ }^{\circ} \mathrm{C}$ with a flowing electrolyte, the self-discharge rate can reach $2.3 \%$ charge capacity per hour [90]. More expensive ion exchange membranes are also suitable and have been studied since the earliest developments, e.g., Nafion ${ }^{\mathrm{TM}}$ [91], or Asahi ${ }^{\mathrm{TM}}$ [67]. Membranes based on chloromethylated polysulfone functionalized with trimethylamine groups have been claimed to be particularly suitable [92] and a carbon-coated membrane (in the positive half-cell side) has been considered [93]. In contrast to other RFBs, the literature on separators for the $\mathrm{Zn}-\mathrm{Br}_{2}$ system is scarce.

The $\mathrm{Zn}-\mathrm{Br}_{2}$ system has been described in a book chapter by Butler et al. [52] and an encyclopaedia article [44]. A book by Rajarathnam and Vasallo [94] considers some aspects of the battery, including the $\mathrm{Zn}$ electrodeposition reaction and the bromine electrode process from the perspective of ionic liquids as well as strategies for further development. The electrochemical engineering characteristics of the devices and their critical importance for high performance were not discussed. Other academic studies have considered miniaturized $\mathrm{Zn}-\mathrm{Br}_{2}$ flow cells [95] and cage-like porous carbon materials [96].

\subsection{The zinc negative electrode}

The negative electrode process involves the cyclic electrodeposition and dissolution of $\mathrm{Zn}$. As explained below, electrolyte additives are used to help control the deposit morphology. 
The $\mathrm{Zn}-\mathrm{Br}_{2}$ battery typically uses 2-D planar carbon-polymer composite bipolar electrodes manufactured by polymer extrusion. A more uniform current and potential distribution is easier to achieve at 2-D electrodes and has traditionally promoted uniform, compact $\mathrm{Zn}$ electrodeposits. The metal layer should have good adhesion to the substrate but be easily dissolved during discharge.

A typical bipolar electrode composition for this system utilises carbon powder mixed with polypropylene [97], polyethylene [69], or carbon black and glass fibre. The content of conductive carbon filler has to be enough to provide adequate conductivity without decrement in mechanical properties. Korean research workers [98] have characterised a polypropylene/carbon/carbon nanotube composite electrode manufactured by sheet extrusion. The composite electrodes, with a CNT content of 5\% w.t., had a resistivity of $1.12 \Omega \mathrm{m}$. Neither the activity towards the positive reaction nor the negative Zn nucleation and adhesion were studied. A $\mathrm{Zn}-\mathrm{Br}_{2}$ cell with such bipolar plates showed voltage and energy efficiencies of $80.7 \%$ and $73.2 \%$, respectively. The mechanical properties of the bipolar electrodes were improved. However, it has been shown that expensive multi-walled carbon nanotubes (MWCNT) disperse poorly in a similar polyethylene-based composite bipolar electrode, having a negative effect of $\mathrm{Zn}$ electrodeposition [69]. As shown in Figure 7, the onset potential for $\mathrm{Zn}$ nucleation becomes more negative at the electrode containing carbon nanotubes while the current density diminishes in comparison to the conventional substrate.

The homogeneousness and morphology of the $\mathrm{Zn}$ deposits have critical importance for the cycling lifetime of the device. Dendritic growths are known to pierce separators and detach from the electrode, decreasing capacity and efficiency and potentially blocking manifolds. 
Aspects that affect the $\mathrm{Zn}$ deposit include: a) flow regime, b) electrolyte composition, c) electrolyte additives, d) nucleation at the carbon bipolar electrode. The flow regime within the electrode compartment has some influence over the electrodeposition of $\mathrm{Zn}$, so a controlled, uniform flow from minimal manifold jets is required. These effects can also be observed in small laboratory cells [99]. Furthermore, the change in the flow channel resulting from the accumulation or dissolution of $\mathrm{Zn}$ has some effect on the cell performance [100]. Another problem resulting in poor utilization of the active material is the hampered dissolution of $\mathrm{Zn}$, e.g. in [88]. In practice, the formation of dendrites is decreased and the electrode can be re-established by performing regular stripping cycles with a discharge cell potential as low as $1.0 \mathrm{~V}[67]$.

Electrolyte additives such as tetraalkylammonium and pyridinium cations have been used to minimise dendrite growth in the acid bromide-containing supporting electrolytes used in $\mathrm{Zn}$ $\mathrm{Br}_{2}$ batteries [101-103]. Fluorinated surfactants and 10\% w.t. butyrolactone reduced $\mathrm{Zn}$ dendrite formation on an RVC electrode [104]. Recently, the effect on Zn morphology and charge efficiency produced by the changing electrolyte concentration and the presence of small amounts of impurities has been studied [88]. Additives can also help mitigate selfdischarge by inhibiting the oxidation of the zinc deposit by bromine [78]. $\mathrm{NH}_{4} \mathrm{Cl}$ [65] or $\mathrm{KCl}$ [52] can be added to the electrolyte to increase conductivity.

Planar electrodes have the disadvantage of limited surface area available and porous, 3-D electrodes have been investigated to extend the available area for $\mathrm{Zn}$ deposition. However, the ohmic drop that takes place through porous electrodes (higher than in monolithic electrodes) and in the electrolyte permeating the porous structure can result in non-uniform 
metal deposition and metal dissolution. Such effects were observed in a $\mathrm{Zn}^{-\mathrm{Br}_{2}}$ battery using 45 and 100 ppi reticulated vitreous carbon $(\mathrm{RVC})$ electrodes [104]. In the $10 \times 10 \times 0.1 \mathrm{~cm}$ electrodes, the $\mathrm{Zn}$ deposited during charge produced non-uniform deposits, concentrating in the electrode planes up to $0.2 \mathrm{~mm}$ deep into the negative electrode; increased electrolyte flow rate had a very small effect. Corrugated plates and honeycomb electrodes are also a possibility but dendritic growths are difficult to avoid due to heterogeneous potential distribution and edge effects at the electrodes. Electrode geometries tailored by potential/current distribution modelling and computational flow dynamics (CFD) are now possible.

\subsection{The bromine positive electrode}

The bromine/tribromide electrode reaction takes place in the positive side of the carbon-based composite bipolar electrodes. Wang et al. [105] have studied the activity of acetylene black, expanded graphite, carbon nanotubes and carbon black commercial carbon filling materials towards the $\mathrm{Br}_{2} / \mathrm{Br}^{-}$redox couple by several techniques. Electrodes having a high surface area, surface porosity and good conductivity result in high reaction rates; carbon black has shown a particularly high electrochemical activity. Munaiah et al. [106, 107] have shown that single walled carbon nanotubes (SWCNT) appear to have a higher electrocatalytic activity for the $\mathrm{Br}_{2} / \mathrm{Br}^{-}$reaction when incorporated into a carbon felt electrode. The same authors have considered exfoliated graphene-based electrodes [108]. The stability of expensive nanomaterials on electrode surfaces is likely to be insufficient during long-term operation and it is difficult to improve on the practicality and economy of classical activated (e.g., coconut shell) carbon.

The limited performance of planar electrodes for the positive electrode reaction should also be considered. In the 80s, Energy Research Corporation used carbon felt positive electrodes 
bonded to the carbon bipolar plates [64]. With these electrodes, coulombic and voltage efficiencies of $89 \%$ and $84 \%$ were achieved in unit cells, although the pressure difference between the positive and negative compartments was problematic in the stacks, while a faster reaction rate at the positive electrode might result in cell imbalance. In other words, the application of 3-D porous electrodes for the bromine reaction is subject to the efficiency of the negative $\mathrm{Zn}$ deposition/dissolution electrode reaction.

A divided $\mathrm{Zn}-\mathrm{Br}_{2}$ battery with a semi-solid positive electrode comprised of a slurry of carbon black and zinc bromate in a carbon felt has been used to decrease the emissions of bromine [109]. At $20 \mathrm{~mA} \mathrm{~cm}^{2}$, the cell yielded coulombic and energy efficiencies of $92 \%$ and $82 \%$, respectively. Nevertheless, such design is not suitable for utility-scale applications in view of active material limitations. Precious metal catalysts can be advantageous for the bromine electrode reaction, e.g. [110], although cost and serious safety concerns in an environment potentially containing halide gas and corrosive, acidic bromine solutions have discouraged their use.

\subsection{Cell performance}

$\mathrm{Zn}-\mathrm{Br}_{2} \mathrm{RFBs}$ are reliable and reversible, having a cell potential of $c a .1 .82 \mathrm{~V}$, a specific energy of $440 \mathrm{~W} \mathrm{~h} \mathrm{~kg}^{-1}$ and a typical energy efficiency between $65 \%$ and $90 \%$. Batteries containing an organic liquid phase, such as a quaternary ammonium salts, to increase the efficiency of bipolar cells stacks are able to deliver between $2 \mathrm{~kW}$ and $10 \mathrm{~kW}$ h at room temperature. All the electroactive materials are low cost and abundant but the system presents the typical current leakage and pressure drop problems of bipolar, parallel plate reactors that result in energy loss. Careful manifold and electrode design is required to distribute the electrolyte and reduce leakage currents. 
The operating current density at planar electrodes has usually been 15 to $30 \mathrm{~mA} \mathrm{~cm}^{-2}$ [52], and appears to be limited to $40 \mathrm{~mA} \mathrm{~cm}^{-2}$ during charge, due to the onset of dendritic deposition [29]. It is understood that discharge has been possible at $80 \mathrm{~mA} \mathrm{~cm}^{-2}$, for short periods of time. In contrast, $\mathrm{H}_{2}-\mathrm{Br}_{2}$ systems are reported to be capable of discharge at $700 \mathrm{~mA} \mathrm{~cm}^{-2}$ at a cell potential of $0.8 \mathrm{~V}$ [111], notwithstanding their inherent health and safety concerns.

Despite improvements in cell stack manufacture, choice of materials and device lifetime, the reported energy efficiency of the $\mathrm{Zn}-\mathrm{Br}_{2}$ battery has shown only small improvements due to the limited area of the planar electrode for $\mathrm{Zn}$ deposition. More than three decades ago, Johnson Controls developed a $20 \mathrm{~kW}$ h load management system that operated at coulombic and energy efficiencies of $80 \%$ and $60 \%$, respectively, at $28 \mathrm{~mA} \mathrm{~cm}^{-2}$ [65]. The $80 \mathrm{~kW} \mathrm{~h}$ Meindensha Electric system operated at $13 \mathrm{~mA} \mathrm{~cm}^{-2}$ giving an overall efficiency of $67 \%$ after 250 cycles [66]. A 30 cell stack with $872 \mathrm{~cm}^{2}$ bipolar electrodes (and carbon felt at the positive side) by Energy Research Corp. operating at a current density $34.4 \mathrm{~mA} \mathrm{~cm}^{-2}$ produced, voltage and energy efficiencies of $84.9 \%, 73.5 \%, 62.4 \%$, respectively [64]. A better performance was later achieved by the SEA GmbH automotive battery, which could achieve maximum coulombic efficiencies $95 \%$ and voltage efficiencies of $86 \%$ [52]. In 1999, the Sandia National Laboratory cell design for utility-scale tested in a $1 \mathrm{~kW}$ h pilot device was claimed to yield an average coulombic efficiency of $77 \%$ with a voltage efficiency of $74 \%$ [67].

Recent testing has focused on the utility performance of the now more mature technology. In 2013 Sandia National laboratories reported the performance of remote, standalone $10 \mathrm{~kW} \mathrm{~h}$ $\mathrm{Zn}-\mathrm{Br}_{2}$ batteries coupled to diesel generators for telecommunication applications [90]. The 
batteries showed energy efficiencies between 67.5 and $73.2 \%$, depending on ambient temperature, permitting maximum fuel savings of $60 \%$ when the electrical demand was low $(1 \mathrm{~kW})$, decreasing to $10 \%$ with higher demands $(5 \mathrm{~kW})$. Primus Power has tested a $72 \mathrm{~kW} \mathrm{~h}$ grid levelling system in California, noting that short charge/discharge operation fomented dendritic deposits, although this could be managed with weekly 15-30 min. stripping cycles [112]. Using twelve $10 \mathrm{~kW} \mathrm{~h} \mathrm{modules,} \mathrm{an} \mathrm{energy} \mathrm{storage} \mathrm{system} \mathrm{was} \mathrm{built} \mathrm{by}$ Raytheon/KTech (USA) for Sandia National Laboratories [113]. The overall efficiency of the system was $48.1 \%$. The power per frequency curve of the energy system showed a near linear behaviour with some hysteresis due to a delayed response. The evaluated power and frequency ranges were -18 to $12 \mathrm{~kW}$ and 59.54 to $60.48 \mathrm{~Hz}$, respectively.

Figure 8 shows an example of a commercial $10 \mathrm{~kW} \mathrm{~h} \mathrm{Zn}-\mathrm{Br}_{2}$ system (Redflow Ltd.), comprising a stack of bipolar cells, reservoirs to accommodate the electrolytes $\left(100 \mathrm{dm}^{3}\right)$, pumps and a control unit [114]. The manifolds are next to the cell stack and sealed to the capillary tubes of the cell stack frames. The device has a nominal voltage of $48 \mathrm{~V}$, a nominal power of $3 \mathrm{~kW}$, an energy efficiency of $80 \%$ and its guaranteed for 10 years or $36,500 \mathrm{~kW} \mathrm{~h}$ of delivered energy. The same company offers a larger, $600 \mathrm{~kW}$ h capacity $\mathrm{Zn}-\mathrm{Br}_{2} \mathrm{RFB}$ for utility applications as well as a $10 \mathrm{~kW}$ h system intended for home use.

\subsection{Prospects for zinc-bromine redox flow batteries}

The $\mathrm{Zn}-\mathrm{Br}_{2} \mathrm{RFB}$ remains a viable alternative for electrical energy storage in the market for $10 \mathrm{~kW}$ to $10 \mathrm{MW}$ in terms of cost, rapid response to electricity demands, reliability and durability. Thanks to its high reversibility, specific energy, cell voltage and energy efficiency the system continues to be popular in research institutions and the industry, especially in the 
Asia and Australia. New developments in electrode materials, such as composites carbon nanotubes [78, 107], and electrolyte materials [115] have been proposed to increase the efficiency. There are still many challenges, including electrode manufacture, reversibility of each electrode (especially at the $\mathrm{Zn}$ electrode due to phase changes), bromine retention in order to avoid leakages and maintain effective health and safe operating conditions. Despite its challenges, the $\mathrm{Zn}-\mathrm{Br}_{2} \mathrm{RFB}$ has reached industrial scale and been commercialised by several companies.

Notwithstanding the potential of the $\mathrm{Zn}-\mathrm{Br}_{2}$ battery to serve as a model system for simulation due to its highly reversible reactions, relatively few papers have been published on mathematical modelling, since early work in the 1980's by Evans et al. [116]. This early paper revised various types of models that include material balance, migration, current and potential distributions, shunt currents and associated energy losses, energy efficiency predictions. Other simulations of faradaic efficiency [117] and current distribution [118] have been published, but are now out of date. Recently, a conference on simulation has focused the crossover of bromine ions [119]. Advances in computational modelling and CFD simulations offer the opportunity to develop full working models to routinely predict (and improve) the effect of construction and operational variables on the performance of the $\mathrm{Zn}-\mathrm{Br}_{2}$.

\section{Zinc-cerium redox flow batteries}

The Zn-Ce RFB benefits from the high positive standard potential of the $\mathrm{Ce}(\mathrm{III}) / \mathrm{Ce}(\mathrm{IV})$ redox couple and is made possible by the ample solubility of cerium ions in methanesulfonic acid solutions [120]. This battery was introduced in 2004 in a US Patent application [55], as a logical spin-off to the routine industrial generation of $\mathrm{Ce}(\mathrm{IV})$ oxidant for mediated 
electrosynthesis at Pt/Ti anodes [121]. The state of the art Zn-Ce hybrid RFB has been summarized by Walsh et al. [122] and by Xie et al. [123].

Zinc deposition and dissolution, reaction (1), takes place in acid media at the negative electrodes. The conversion of $\mathrm{Ce}(\mathrm{III})$ and $\mathrm{Ce}(\mathrm{IV})$ ions occurs at the positive electrode:

$$
\mathrm{Ce}(\mathrm{IV})+\mathrm{e}^{-} \underset{\text { Charge }}{\rightleftarrows} \mathrm{Ce}(\mathrm{III})
$$

The standard potential for this reaction is $1.61 \mathrm{~V} v s$. SHE in methanesulfonic acid and the resulting open-circuit cell potential is $c a .2 .37 \mathrm{~V}$. Figure 4c) shows a unit flow cell divided by a proton exchange membrane and $\mathrm{Zn}(\mathrm{II})$ and $\mathrm{Ce}(\mathrm{III})$ methanesulfonate electrolytes before charge.

Overall, electrode materials and electrolyte compositions have been studied. The main limitation of the $\mathrm{Zn}-\mathrm{Ce}$ RFB is the high cost of Pt/Ti electrodes and electrolyte cross-mixing. Current research needs to address the imbalance of the cell and self-discharge produced by the parasitic $\mathrm{H}_{2}$ evolution at the negative electrode. The membrane-divided $\mathrm{Zn}$-Ce battery has received much attention, although an undivided system using a laboratory, single electrolyte cell has also been proposed. The energy efficiency and feasibility of these devices, along with results from a scale-up industrial pilot installation are discussed in the following sections.

\subsection{The zinc negative electrode}

The negative half-cell of the battery depends on the nucleation and stripping of zinc in aqueous methanesulfonic acid, conditions that favour $\mathrm{H}_{2}$ evolution in comparison to alkaline 
media. In view of the initial attempts to use carbon-based bipolar electrodes in $\mathrm{Zn}-\mathrm{Ce}$ stacks, the positive electrode reaction has mainly been studied at carbon composite substrates [124127]. The $\mathrm{Zn}(\mathrm{II}) / \mathrm{Zn}$ redox couple has fast kinetics in methanesulfonate acid and low overpotentials are observed for the deposition and redissolution reactions [127]. This is shown in a cyclic voltammogram for $\mathrm{Zn}$ (II) methanesulfonate at glassy carbon in Figure 9. An overpotential of $c a .100 \mathrm{mV}$ is required to drive $\mathrm{Zn}$ nucleation; the actual deposition starts at a potential of $-1.19 \mathrm{~V} v$ s. SCE. In the reverse direction, the voltammogram shows the oxidation current peak due to an unhindered Zn(II) dissolution at -1.07 V vs. SCE [128].

A laboratory RFB using a carbon-polyvinyl ester (PVE) composite as negative electrode along with a negative electrolyte composition of $1.5 \mathrm{~mol} \mathrm{dm}^{-3} \mathrm{Zn}\left(\mathrm{CH}_{3} \mathrm{SO}_{3}\right)_{2}+1 \mathrm{~mol} \mathrm{dm}^{-3}$ $\mathrm{CH}_{3} \mathrm{SO}_{3} \mathrm{H}$ has been characterized [127]. Cell potential profiles over a current density range between 10 and $50 \mathrm{~mA} \mathrm{~cm}{ }^{-2}$ were obtained for different $\mathrm{Zn}(\mathrm{II})$ and $\mathrm{H}^{+}$concentration, operational temperature, the presence of electrolytes additives and increasing mean linear electrolyte flow rate. The battery showed better performance at a current density of $50 \mathrm{~mA}$ $\mathrm{cm}^{-2}$ and $323 \mathrm{~K}$ using $\mathrm{In}(\mathrm{III})$ as inhibitor of $\mathrm{H}_{2}$ evolution. Dendrite-free $\mathrm{Zn}$ deposits were obtained at current efficiencies over $90 \%$ and voltage efficiencies of $c a$. $70 \%$.

The electrodeposition of Zn at polyvinylidene fluoride (PVDF) and high density polyethylene (HDPE) carbon-polymer composite was investigated by another group [126]. Zn nucleation was related to the standard rate constant for the $\mathrm{Zn}(\mathrm{II}) / \mathrm{Zn}$ reaction and the diffusion coefficient of $\mathrm{Zn}(\mathrm{II})$ ions. Nuclei density was estimated and confirmed to increase as a function of overpotential. Charge/discharge cycling at rotating disc electrodes using $1.5 \mathrm{~mol} \mathrm{dm}^{-3}$ $\mathrm{Zn}\left(\mathrm{CH}_{3} \mathrm{SO}_{3}\right)_{2}$ in $5.7 \mathrm{~mol} \mathrm{dm}^{-3} \mathrm{CH}_{3} \mathrm{SO}_{3} \mathrm{H}$ at $333 \mathrm{~K}$ showed that the deposition and dissolution reactions required only small overpotentials. In the same experiments, the PVDF material 
displayed a superior charge efficiency of $>95 \%$ during multiple cycles. The stability of six different carbon/polymer composites was later studied by the same researchers [125]. The effect of temperature over $298-333 \mathrm{~K}$ and mass transport in rotating disc experiments showed that higher temperatures favoured the kinetics of $\mathrm{Zn}$ deposition and dissolution, while increasing rotation rates resulted in current density for such reactions, although this effect was due in part to the removal of $\mathrm{H}_{2}$ bubbles. PVDF and PVE showed good cycling stability over 180 simulated charge/discharge cycles. It has also been demonstrated that the incorporation of $\mathrm{In}(\mathrm{III})$ into graphite electrodes can inhibit $\mathrm{H}_{2}$ evolution at the bare material during charge [124]. This strategy increased the current efficiency of a $\mathrm{Zn}$-Ce cell from $71 \%$ to $83 \%$ and reduced the overpotential associated to the ageing of the material after multiple cycles.

As in other Zn-based RFBs, the deposition of uniform thick zinc layer with a compact microstructure onto the current collector is necessary during the charge process. The morphology of such deposits is influenced by the material/form of the current collector, charge regime, electrolyte composition and hydrodynamics [129]. The morphology of $\mathrm{Zn}$ deposits has been related to the operational current density of the battery via Hull cell experiments using an improved electrolyte composition with $2.5 \mathrm{~mol} \mathrm{dm}{ }^{-3} \mathrm{Zn}\left(\mathrm{CH}_{3} \mathrm{SO}_{3}\right)_{2}$ in $1.5 \mathrm{~mol} \mathrm{dm}^{-3} \mathrm{CH}_{3} \mathrm{SO}_{3} \mathrm{H}$ [130]. As shown in Figure 10, current densities under $15 \mathrm{~mA} \mathrm{~cm} \mathrm{~cm}^{-2}$ failed to cover the carbon composite surface in these experiments. Between $15 \mathrm{~mA} \mathrm{~cm}^{-2}$ and $30 \mathrm{~mA} \mathrm{~cm}{ }^{-2}$ the electrodeposited $\mathrm{Zn}$ is smooth overall. A desirable operation approaching current densities of $80 \mathrm{~mA} \mathrm{~cm}{ }^{-2}$ could be difficult to implement due to the formation of rougher and deposits at the electrode. $\mathrm{H}_{2}$ evolution will be favoured during the charge process at higher current densities, not to mention the self-discharge mechanism due to corrosion of zinc. 
Several strategies to address these issues can be found in the industrial zinc electrodepostion from sulfuric acid, although the deposit thickness in these processes is generally much thinner and the range of current density is lower $\left(<20 \mathrm{~mA} \mathrm{~cm}^{-2}\right)$ than required in a RFB. As shown in Table 4, numerous electrolyte additives have been considered for electroplating and electrowinning to control the deposit morphology and decrease $\mathrm{H}_{2}$ evolution in acid media:

$$
2 \mathrm{H}^{+}+2 \mathrm{e}^{-} \rightarrow \mathrm{H}_{2}(\mathrm{~g})
$$

For instance, glue [103] and gum Arabic [137] are additives of natural origin that have been used for decades in Zn electrowinning from sulfuric acid. As seen in Table 3, Tripathy et al. systematically analysed the effect of various types of surfactants on the electrodeposition of Zn. Other additives suggested in the literature include diverse organics, some highly-stable perfluorinated compounds and inorganic ions. All of these additives have been reported to suppress parasitic $\mathrm{H}_{2}$ evolution and enable control of $\mathrm{Zn}$ morphology.

In the case of $\mathrm{Zn}$ corrosion in methanesulfonic acid media, tetrabutylammonium ions and butyltriphenylphosphonium ions have shown effectiveness for the inhibition of $\mathrm{H}_{2}$ evolution [146]. However, the effect was limited to a few hours, indicating the need for inhibitors able to remain in the battery electrolyte for long periods of time. Inorganic ions, such as $\mathrm{Bi}^{3+}$, may be more suitable.

\subsection{The cerium positive electrode}

Early information on the $\mathrm{Ce}(\mathrm{IV}) / \mathrm{Ce}(\mathrm{III})$ redox couple in methanesulfonic acid has been the result of developments in the anodic generation of $\mathrm{Ce}(\mathrm{IV})$ ion oxidants for mediated electrosynthesis; the anodic $\mathrm{Ce}(\mathrm{III})$ oxidation at $\mathrm{Pt} / \mathrm{Ti}$ mesh electrode has proven reliable in 
several industrial electrochemical processes [23]. The Ce(IV)/Ce(III) redox couple is quasireversible, as demonstrated by the voltammetric studies by Vijayabarathi et al. [147] and Devadoss et al. [148]. More recently, studies for cerium-based RFBs have shown that both oxidation and reduction reactions have suitable kinetics for RFBs [149-151], although at least one slow reaction step can hinder charge transfer due to the re-organization of the methanesulfonate ligands during the electrode reaction [123]. The high solubility of cerium species in methanesulfonic acid enable their use in aqueous electrochemistry [120], although it declines above acid concentrations above $4 \mathrm{~mol} \mathrm{dm}^{-3}$. The concentration of Ce(IV) methanesulfonate can reach up to $1.0 \mathrm{~mol} \mathrm{dm}^{-3}$, setting a limit for the volumetric energy density of the Zn-Ce RFB. In sulfuric acid, the kinetics of cerium methanesulfonate redox processes are irreversible and their maximum solubility is $0.125 \mathrm{~mol} \mathrm{dm}^{-3}$ [122], making this supporting electrolyte unsuitable for RFB applications. Xie et al. [149] have reported that that both $\mathrm{Ce}(\mathrm{IV})$ and $\mathrm{Ce}(\mathrm{III})$ ions are soluble up to $333 \mathrm{~K}$. At higher temperatures, $\mathrm{Ce}(\mathrm{IV})$ methansulfonate precipitates from the electrolyte when the concentration of $\mathrm{Ce}(\mathrm{IV})$ ions is $c a$. $0.6 \mathrm{~mol} \mathrm{dm}^{-3}$.

Several electrode materials have been reported for the positive half-cell reaction and the effect of charge-discharge regimes in the Zn-Ce RFB [152]. Although carbon felt electrodes yielded the highest cell potential at a current density of $50 \mathrm{~mA} \mathrm{~cm}^{-2}$, its low stability meant that $\mathrm{Pt} / \mathrm{Ti}$ mesh was more suited to use in an RFB. Xie et al. [149] also performed experiments in a ZnCe flow cell using a $3 \mathrm{~mm}$ thick carbon felt as positive electrode allowed to obtain a charge efficiency of $86 \%$ and an energy efficiency of $75 \%$ under a regime of one hour charges and discharges at a constant current density of $30 \mathrm{~mA} \mathrm{~cm}^{-2}$. On the other hand, in a laboratory divided flow cell with a Pt/Ti mesh electrode the conversion of $\mathrm{Ce}(\mathrm{III})$ to $\mathrm{Ce}(\mathrm{IV})$ was possible at a current efficiency of more than $75 \%$ [152]. In the same study, the concentration of 
methanesulfonic acid in the battery was optimized. High acid concentrations increase the solubility of $\mathrm{Ce}(\mathrm{IV})$ but have the opposite effect on the solubility of $\mathrm{Ce}(\mathrm{III})$. If the concentration of acid is too high, the mass transfer coefficient at the electrode diminishes due to the higher viscosity of the electrolyte. Several alternative catalysts such as Pt-Ir and Pt deposited on etched or sandblasted Ti have been investigated in planar electrodes for the ZnCe battery [153]. It was found that the $\mathrm{Pt}-\mathrm{IrO}_{2}$ electrodes were comparable to Pt electrodes and that operation over $25 \mathrm{~mA} \mathrm{~cm}^{-2}$ at a planar resulted in severe $\mathrm{O}_{2}$ evolution during charge.

With the purpose of enhancing the kinetics of the $\mathrm{Ce}(\mathrm{IV}) / \mathrm{Ce}(\mathrm{III})$ reaction and increasing the stability of $\mathrm{Ce}(\mathrm{IV})$ ions in solution, alternative support electrolyte compositions based on mixed acids have been proposed. For instance, the exchange current density and standard rate constant for an electrolyte containing $0.3 \mathrm{~mol} \mathrm{dm}^{-3} \mathrm{Ce}(\mathrm{III})$ in $2 \mathrm{~mol} \mathrm{dm}^{-3} \mathrm{MSA}+0.5 \mathrm{~mol} \mathrm{dm}^{-}$

${ }^{3} \mathrm{H}_{2} \mathrm{SO}_{4}$ were higher in comparison to an electrolyte using MSA as the supporting electrolyte, yielding an energy efficiency of $73 \%$ [154]. Other researchers [155] reported that adding 0.5 mol dm ${ }^{-3} \mathrm{HCl}$ to $0.6 \mathrm{~mol} \mathrm{dm}{ }^{-3} \mathrm{Ce}(\mathrm{III})$ in $4 \mathrm{~mol} \mathrm{dm}^{-3} \mathrm{MSA}$ significantly enhanced the reaction kinetics, exchange current density and electrolyte conductivity.

\subsection{Cell performance}

A 2 kW pilot-scale Zn-Ce battery was evaluated by Plurion Ltd. in Scotland in the 2010s [122]. Each stack consisted of six $0.5 \mathrm{~m}^{2}$ bipolar titanium electrodes, the positive side being welded to Pt/Ti mesh and the negative side coated with a stable catalyst material. Over 25 cycles, the coulombic and energy efficiencies fluctuated around $60 \%$ and $45 \%$, respectively. As these developments were only partially disclosed, most of the available data on Zn-Ce RFBs has been obtained in laboratory-scale flow cells. The classical Zn-Ce cell is divided by a proton fluorocarbon membrane although polymeric microporous separators could also be 
considered. Ambitious attempts to simply construct and improve membrane potential drops using an undivided, single compartment cell have been described [60, 156].

The performance of a small flow cell under various charge/discharge regimes and operational conditions has been described [41]. In this divided RFB, the two half-cells were separated by a Nafion 115 proton exchange membrane. A stack of four $\mathrm{Pt} / \mathrm{Ti}$ meshes and a carbon/polyvinylester composite were used as the positive and negative electrodes, respectively. The positive electrolyte was $1.5 \mathrm{~mol} \mathrm{dm}^{-3} \mathrm{Zn}^{2+}$ in $1.0 \mathrm{~mol} \mathrm{dm}{ }^{-3} \mathrm{CH}_{3} \mathrm{SO}_{3} \mathrm{H}$ and the negative electrolyte was $0.8 \mathrm{~mol} \mathrm{dm}{ }^{-3} \mathrm{Ce}(\mathrm{III})+4 \mathrm{~mol} \mathrm{dm}^{-3} \mathrm{CH}_{3} \mathrm{SO}_{3} \mathrm{H}$. The cell potential during discharge was $1.8 \mathrm{~V}$, for an equivalent energy density of $350 \mathrm{~W} \mathrm{~h} \mathrm{~kg}$. . Higher cell potentials were observed with increasing temperature and electrolyte mean linear flow rate. The cell could operate at current densities up to $80 \mathrm{~mA} \mathrm{~cm}^{-2}$ showing current efficiencies of up to $75 \%$ and voltage efficiencies up to $60 \%$. The negative electrode limits the performance of the cell due to the occurrence of $\mathrm{H}_{2}$ evolution, which is aggravated over multiple cycles. The proton transport through the membrane results in the progressive acidification of the negative electrolyte and enhances the rate of the parasitic reaction. In a study of catalysts for the cerium redox reaction, the use of planar Pt-based electrodes, in contrast to the 3-D porous $\mathrm{Pt} / \mathrm{Ti}$ meshes [155], was shown to be less suitable for the battery. At a current density of 10 $\mathrm{mA} \mathrm{cm}{ }^{-2}$, the observed current efficiencies for various Pt-based catalysts supported on a rotating disc electrode were between $71 \%$ and $83 \%$ while the energy efficiencies were between $62 \%$ and $71 \%$.

In order to tackle this problem and avoid the different concentrations of acid in the two halfcells, an undivided RFB was proposed by the same group $[60,156]$. Such a system eliminates the need for the costly membrane and simplifies the electrolyte flow circuit. This flow cell 
used carbon felt as the positive electrode and was operated at current densities between 20 and $80 \mathrm{~mA} \mathrm{~cm}^{-2}$. During charge/discharge cycles at $20 \mathrm{~mA} \mathrm{~cm}^{-2}$, the battery showed a charge efficiency of $82 \%$ and an energy efficiency of $72 \%$. However, the carbon felt electrodes suffered from degradation and the corrosion of the Zn deposits was enhanced by $\mathrm{Ce}(\mathrm{IV})$ ions. The concentration of cerium ions (and the capacity of the battery) was also limited in the single electrolyte, as high levels of methanesulfonic acid encourage profuse $\mathrm{H}_{2}$ evolution at the negative electrode.

The cell potential components of a divided $\mathrm{Zn}-\mathrm{Ce}$ unit cell have been considered in order to simulate the effects of the measured electrolyte conductivity and interelectrode gap at increasing discharge current density [157]. It is unfortunate that such data is not readily available for other RFBs. The conductivity and stability of several electrolyte compositions were measured and used in a simple mathematical model of the cell potential. It was concluded that porous electrodes are required in order to reduce the local current density at the positive electrodes, while the electrode-membrane gap in the negative half-cell should be kept under $3 \mathrm{~mm}$.

Recently, the volumetric mass transport coefficient, $k_{m} A_{e}$, of diverse porous $\mathrm{Pt} / \mathrm{Ti}$ electrodes for the Zn-Ce RFB has been investigated as an electrode performance factor [59]. It has been shown that planar electrodes are unsuitable as positive electrodes in this system due to the significant potential losses resulting from limited mass transport and electrode area. On the other hand, $\mathrm{Pt} / \mathrm{Ti}$ micromesh and $\mathrm{Pt} / \mathrm{Ti}$ felt electrodes outperformed the previously used meshes. The limiting current for the reduction of $\mathrm{Ce}(\mathrm{IV})$ ions at these structures represented up to 63 and 160 times that achieved at the planar electrodes, respectively. Furthermore, the measured values of $k_{m} A_{e}$ were described as a function of linear flow velocity and the authors 
noted that such figures can be used to approximate the required electrodes dimensions for a desired potential drop in the cell and/or a determined fractional conversion of the electroactive species. Figure 11 shows the charge-discharge profile of a Zn-Ce unit cell employing a Pt/Ti felt as positive electrode and a graphitised fluorocarbon carbon-composite as negative electrode at a constant current density of $20 \mathrm{~mA} \mathrm{~cm}^{-2}$ [158]. The cell failed after 22 cycles due to the imbalance in the state of charge of the positive and negative compartments. The low efficiency of $\mathrm{Zn}$ deposition and redissolution prevented the simultaneous conversion of the cerium electrolyte during the same period of time, resulting in increasingly high concentrations of $\mathrm{Ce}(\mathrm{IV})$.

Recently, Yu and Manthiram [159] have developed a conceptual divided Zn-Ce cell using a $\mathrm{Na}_{3} \mathrm{Zr}_{2} \mathrm{Si}_{2} \mathrm{PO}_{12}$ solid electrolyte, which enables the zinc reaction to take place in alkaline environment, instead of the usual methanesulfonic acid solution. Since the separator is a sodium super ionic conductor (NASICON), the supporting positive and negative electrolytes were $\mathrm{Na}_{2} \mathrm{SO}_{4}$ and $\mathrm{NaOH}$, respectively, limiting the concentration of $\mathrm{Ce}(\mathrm{IV})$ ions to $0.1 \mathrm{~mol}$ $\mathrm{dm}^{-3}$. The device, which has a high open-circuit potential $(2.7 \mathrm{~V})$ compared to other $\mathrm{Zn}-\mathrm{Ce}$ RFBs, endured 50 charge/discharge cycles at $2 \mathrm{~mA} \mathrm{~cm}^{-2}$. In view of the possibility of preventing the parasitic $\mathrm{H}_{2}$ evolution and the self-discharge via zinc corrosion, more research can be expected, particularly on the implementation of concentrated cerium methanesulfonate electrolytes and on the scale-up suitability of NASICON separators.

\subsection{Prospects for zinc-cerium redox flow batteries}

In spite of the early commercial interest and capital investment devoted to the $\mathrm{Zn}-\mathrm{Ce} \mathrm{RFB}$, the system has not yet passed scale-up tests and, therefore, it remains at the laboratory development stage. Significant advances have been achieved in the selection of electrode 
materials, electrolyte compositions and operational conditions, although a comprehensive study of membrane performance and alternative separators has yet to be performed. Important challenges remain in the need for stable, inexpensive bipolar electrodes and the design and manufacture of cell frames. A considerable step towards the practical application of the system could be demonstrated with pilot-scale studies over long-term cycling tests. Still, the main limiting aspect of the cell can be found in the capacity loss resulting from the parasitic $\mathrm{H}_{2}$ evolution reaction at the negative electrode and the relatively large concentration difference of methanesulfonic acid between the positive and negative half-cells. Stable corrosion inhibitors for the negative electrolyte in combination with 3-D negative porous electrodes for $\mathrm{Zn}$ deposition might result in drastic performance improvements, provided that uniform deposits can be obtained.

\section{Zinc-air redox flow batteries}

Primary Zn-air static cells of sheath, prismatic, cylindrical and button cell designs have been commercially available for nearly a century $[42,160]$. A number of reviews have addressed the recent progress of such of cells [161-163], however, secondary Zn-air RFBs still face several developmental problems with both electrodes facing substantial challenges, especially during scale-up efforts.

Both the positive and negative electrode reactions can take place in acidic and alkaline conditions. The potentials for the positive electrode reactions in acid and alkaline, respectively, are:

$$
2 \mathrm{H}_{2} \mathrm{O}-4 \mathrm{e}^{-} \underset{\text { Discharge }}{\stackrel{\text { Charge }}{\rightleftarrows}} \mathrm{O}_{2}+4 \mathrm{H}^{+} \quad E^{0}=1.229 \mathrm{~V} \text { vs. } \operatorname{SHE}(7)
$$




$$
4 \mathrm{OH}^{-}-4 \mathrm{e}^{-} \underset{\text { Discharge }}{\stackrel{\text { Charge }}{\rightleftarrows}} \mathrm{O}_{2}+2 \mathrm{H}_{2} \mathrm{O} \quad E^{0}=0.401 \mathrm{~V} \text { vs. SHE (8) }
$$

As Zn-air cells mostly use alkaline electrolytes, oxygen being reduced to hydroxyl ions at the positive electrode and evolved during discharge and charge respectively.

The Zn-air battery is an attractive system due to its high theoretical energy density of $\sim 1350 \mathrm{Wh} \mathrm{kg}^{-1}$ [54]. In practice, this value is between 350 and $1100 \mathrm{~W} \mathrm{~h} \mathrm{~kg}^{-1}$ [164] which is superior to that of Li-ion batteries. Other advantages such as safety and long operating life, low cost and low environmental impact give this system the potential to be used in various grid energy storage applications. For example, a US-based company Fluidic Energy has installed more than 100,000 rechargeable Zn-air battery systems for small energy storage back-up systems at $\$ 200$ to $\$ 300 / \mathrm{kW} \mathrm{h}$ and is planning to transition into microgrid and minigrid markets $[165,166]$.

However, the challenges facing the zinc-air RFB system include (1) shape change of the negative electrode due to dendrite formation during charge; (2) stability concerns of the electrocatalysts at the positive electrode as it is subjected to harsher conditions of the $\mathrm{O}_{2}$ evolution reaction and high anodic potentials; (3) side reactions such as water electrolysis may also occur in the electrolyte during charging; (4) passivation at open-circuit and $\mathrm{H}_{2}$ evolution during discharge can reduce cycle life.

\subsection{The zinc negative electrode}


The kinetics of the electrode processes in the alkaline Zn-air system were described and analysed in detail by Bockris et al. [167]. Since the parasitic $\mathrm{H}_{2}$ evolution occurs at a significant rate, suitable additives are needed in order to suppress this reaction and to control zinc deposition. Several strategies have been studied, for instance, by employing common electrolyte additives in the zinc electroplating industry, which are typically mixtures of polyvinyl alcohols (PVAs), polyamines (PAs) and quaternary ammonium ions [168]. The effect of these organic additives with a brightener (N-benzyl-3-carboxylpyridinium chloride, $3 \mathrm{NCP}$ ) on zinc morphology have been investigated [169]. The synergetic effect of all three additives caused the deposition to occur at more negative potentials, decrease in the crystal size and changes in crystal growth orientation. Work done on inorganic additives such as lead ions and tungstate ions has shown that concentrations of $1 \times 0^{-4} \mathrm{~mol} \mathrm{dm}^{-3}$ and $0.6 \mathrm{~mol} \mathrm{dm}^{-3}$, respectively for either additive gave more compact deposits with energy efficiencies of $c a$. $60 \%$ [170]. A subsequent study by the same group also showed that lead and quaternary ammonium salts such as tetrabutylammonium ions give compact morphology [171]. The role of organic additives has also been examined in Hull cells, in both acidic and alkaline zinc plating baths. In comparison to carbonyl compounds, thiosemicarbazides and their derivatives, furfuraldehydethiosemicarbazone (FrTSCN) were found to be effective additives, displaying good throwing power, corrosion mitigation, current efficiency of $c a .99 \%$ and glossy deposits [172]. Lee et al. [18] considered the ability of organic acids to hinder the rate of deposition and suppress $\mathrm{H}_{2}$ evolution. Citric acid was concluded to be most effective at inhibiting dendrite formation but least effective at suppressing $\mathrm{H}_{2}$ evolution. A short communication [173] showed that the addition of a surfactant, $2 \%$ sodium dodecyl benzene sulfonate, to a dilute $\mathrm{KOH}$ electrolyte formed a passivation layer thereby increasing the utilisation of the negative electrode. 
Additives to the electrode can be applied as surface coatings or be incorporated in the preparation of the paste or pellet electrodes. For instance, a thin layer of $\mathrm{Al}_{2} \mathrm{O}_{3}$ was found to not only suppress $\mathrm{H}_{2}$ evolution but also to maintain discharge capacity extending cycle life in a $9 \mathrm{~mol} \mathrm{dm}^{-3} \mathrm{KOH}$ electrolyte [174]. The use of pasted electrodes based on a mixture of zinc powder, $4 \% \mathrm{PTFE}$, up to $10 \%$ cellulose and $2 \% \mathrm{PbO}$ (mass percentage) in a $\mathrm{Zn}$-air battery has been described [175]. Such electrodes accounted for a modest extension of achieved number of cycles. A subsequent study [176] on the addition of cellulose and $\mathrm{PbO}$ to the electrode demonstrated that cellulose was more effective in ensuring a uniform morphology. Furthermore, the use of zinc alloys incorporating inhibitors as negative electrodes, e.g., $\mathrm{Zn}_{0.9} \mathrm{Ni}_{0.075} \mathrm{In}_{0.025}$ [87], has been shown to decrease the formation of dendrites as well as the parasitic reaction rate.

The influence of mass transport on $\mathrm{Zn}$ morphology in $\mathrm{KOH}$ solution was investigated [177], and flow described by Reynolds number and current densities was found to relate to morphology. In the laminar regime, dendrites decreased with higher flow rates, while compact deposits were achieved in turbulent flow regime. Ito et al. [178] showed that a flow rate over $15 \mathrm{~cm} \mathrm{~s}^{-1}$ helped to improve the cycle life of a zinc negative electrode even at high charge rates as the velocity of the flow encouraged the growth of the dendrites in the same direction, thus prolonging the time till the system short-circuited. A plate-and-frame filter-press, refuellable Zn-air fuel cell [179] with specially designed anode flow channels in two different orientations and assemblies suggested that both aspects of design were important in controlling electrolyte flux and therefore zinc dendrite formation and $\mathrm{H}_{2}$ evolution.

Other dendritic growth suppression strategies have been investigated. For instance, a regenerative Zn-air fuel cell designed by Smedley et al. [180] demonstrated that the dendrite 
formation could be controlled by reducing the presence of negative electrode or increasing the presence of positive electrode in zones more prone to dendrite formation, i.e., modified electrode frames. Meanwhile, Parker et al. [181] fabricated a three-dimensional zinc sponge electrode which remained dendrite free after being cycled to $188 \mathrm{~mA} \mathrm{~h} \mathrm{~g}^{-1}(\mathrm{Zn})$ in an $\mathrm{Ag} / \mathrm{Zn}$ cell. Subsequently, Yan et al. [182] designed a $\mathrm{Zn} / \mathrm{Cu}$ three dimensional foam electrode which gave a specific capacity up to $620 \mathrm{~mA} \mathrm{~h} \mathrm{~g}^{-1}(\mathrm{Zn})$ after 9000 cycles in a Zn-Ni battery. Pulsed current for the control of zinc electrodeposition in $\mathrm{KOH}$ electrolytes was reported by Shaigan et al. [183], proving more effective when using high frequencies and more diluted solutions. Numerical models of zinc electrodeposition have also been developed for these cells [184]. In this way, the interplay between mass transport, changing surface roughness, and operational conditions has been studied, showing that, although adequate flow rates can minimize the generation of dendrites, gas evolution decreases the overall efficiency of the device. The formation mechanism of zinc dendrites was further investigated using an electrochemical phase-field model in a rechargeable three electrode configuration altering factors such as pulsating current and electrolyte flux to effectively suppress dendrite formation and propagation [185]. Three-dimensional models are useful in understanding and determining the variables controlling and affecting the growth and propagation of zinc dendrites.

\subsection{The oxygen positive electrode}

Oxygen reduction and oxygen evolution take place more efficiently at GDEs at low current densities and minimal overpotentials. Typical electrode materials based on carbon paper coated with a precious metal oxide catalyst supported on carbon particles have shown limited stability [56, 186-194] and efforts have been directed towards developing alternative inexpensive catalysts. In acidic systems, bifunctional catalysts are commonly precious metals 
with Pt or Ir or mixed oxides of Rh, Ru or Ir. In alkaline electrolytes, there is a more extensive range of catalysts available - precious metals, mixed metal oxides, manganese dioxide and complexes. So far, however, there is not enough research carried out on the practical use of such bifunctional catalysts in Zn-air flow-cell systems at high current densities and long-term cycling tests.

There are electrodes which do not comprise any carbon components [195-197], however these were developed for fuel cell technology and have not been validated to withstand the conditions of $\mathrm{O}_{2}$ evolution. Lee et al. [198] describes a bifunctional positive electrode of $\mathrm{Co}_{3} \mathrm{O}_{4}$ nanowire arrays grown on a stainless steel mesh without a binder and placed onto a carbon paper backing. The electrode was cycled in a unit cell with polypropylene membrane as a separator in $6.0 \mathrm{~mol} \mathrm{dm} \mathrm{dm}^{-3} \mathrm{KOH}$ for over 600 hours at $50 \mathrm{~mA} \mathrm{~cm}{ }^{-2}$ with a potential difference of about $1 \mathrm{~V}$ between the two reactions. Promising results have been reported for bifunctional $\mathrm{Zn}$-air electrodes based on low cost $\alpha-\mathrm{MnO}_{2}$ [199-201] and enzymes such as bilirubin oxidase (BOD) [202].

An example of carbon-free, bifunctional GDEs for $\mathrm{O}_{2}$ reduction/evolution fabricated with nickel components was reported by Li et al. [203]. The electrode consisted of a nickel cobalt oxide spinel catalyst prepared via thermal decomposition. The catalyst layer was coated onto the PTFE-bonded Ni powder layer on a thin foam of the same metal by dip-coating. Later work [204], showed the effects of PTFE and Ni powder content and preparation procedures in such electrodes. The comparative performance of $\mathrm{O}_{2}$ electrodes employing spinel powder and those only coated by the catalyst as a function of current density is given in Figure 12. The suitability of nickel cobalt spinel over cobalt spinels was confirmed by the same group [205], showing also that it is possible to deposit such catalysts on stainless steel cloth. 
Recently, the group of Chen at al. [206] has developed bifunctional catalysts based on amorphous iron cobalt oxides and graphene on a nickel foam substrate. A $1 \mathrm{~cm}$ x $1 \mathrm{~cm}$ Zn-air cell employing these catalysts was able to deliver a peak power density of $86 \mathrm{~mW} \mathrm{~cm} \mathrm{c}^{-2}$, enduring 60 charge-discharge cycles at a current density of $10 \mathrm{~mA} \mathrm{~cm}^{-2}$.

Another challenge in alkaline $\mathrm{Zn}$-air batteries is the progressive absorption of atmospheric $\mathrm{CO}_{2}$ by the electrolyte, which results in the formation of carbonates [207]. Increasing concentrations lead to a faster rate of carbonate precipitation in the electrolyte, clogging the pores of the gas diffusion layer $[208,209] . \mathrm{CO}_{2}$ filters and chemical scrubbers such as piperazine (PZ) [210] have been shown to be effective in controlling the $\mathrm{CO}_{2}$ concentration. An example of this is a commercial amine adsorbent produced by Oy Hydrocell Ltd. [211], which is capable of removing $\mathrm{CO}_{2}$ from the feed. Few practical $\mathrm{Zn}$-air studies have accounted for this degradation mechanism although this is a well-known disadvantage.

Membrane electrode assemblies (MEA) taken from fuel cell technology can act as a physical barrier, preventing the blockage of the gas channels in the gas diffusion layer as well as leakage of the electrolyte out of the electrode. For a Zn-air battery system, an anion exchange membrane is required. However, the performance and stability of these are not yet comparable to that of cation-exchange membranes $[212,213]$ and more should be done to improve their properties.

Alternative studies [214, 215] describe cells where the reactions for oxygen reduction and evolution are separated and the electrodes can be optimised separately for these reactions by placing an auxiliary electrode either between the positive electrode for discharge and negative electrode or on the opposite side of the negative electrode to give a three electrode 
configuration. In a prototype designed by Postula et al. [216] each cell has a knife switch to connect the negative electrode to the positive or auxiliary electrode for discharge or charge. In a stack, these switches were grouped together for simultaneous operation. The configuration of a tri-electrode cell is an important design factor of a functioning flow system during charge due to oxygen bubble detachment and coalescence phenomena [217]. Bockelmann et al. [218] designed a three electrode rechargeable zinc-oxygen configuration with the positive electrodes for charge and discharge adjacent to one another and reported that the cell was capable of being cycled at $50 \mathrm{~mA} \mathrm{~cm}^{-2}$ for over 600 cycles with an efficiency of $54 \%$, although dendrite formation was not accounted for.

\subsection{Cell developments}

As reviewed, the zinc-air system possesses advantages such as a high energy density, relatively high open-circuit voltage, and low-cost materials etc., which are seen to be promising. However, challenges facing to system R \& D are also equally crucial, such as the activity and stability of catalysts for oxygen evolution and reduction remains to be further explored, the common problem of zinc dendrite growth at negative electrode when charging is as one of the major challenges to the system; in addition, the effective removal of $\mathrm{CO}_{2}$ from the air feed is another task. Despite these challenges, great effort R\&D efforts on the cell have been made by research groups and companies all around the world.

The concept of the Zn-air RFB has its earliest precedent in a 1966 US Army project [48]. Later Fleischmann et al. [49] described a fluidised bed zinc negative electrode as a means to improve the performance of such devices. Ross and Müller developed Zn-air cells with threedimensional copper foam negative electrodes for zinc deposition [219,220]. The porous foam electrodes ensured smooth electrolyte flow through the cell and enabled an even deposition 
of zinc over a large number of cycles. For example, Müller et al. reported cycling a bipolar seven cell stack $\left(100 \mathrm{~cm}^{2}\right)$ using a bifunctional perovskite catalyst with a peak power output of $90 \mathrm{~W}$ although no performance stability vs. time data was reported.

In order to cope with the challenges of bifunctional catalysts for positive electrodes, cell designs that omit the need for them have been developed. A flow cell whereby the positive electrode was constructed of the $\mathrm{O}_{2}$ evolution and reduction catalyst layers one on top the other on Ni foam and pressed together at $12 \mathrm{MPa}[61]$. The cell was cycled in $\mathrm{KOH} / \mathrm{LiOH} /$ $\mathrm{ZnO}$ electrolyte for 150 cycles at $60{ }^{\circ} \mathrm{C}$ with a charge efficiency of $>96 \%$ and energy efficiency of $c a$. $72 \%$. Ma et al. attempted to physically combine catalysts for $\mathrm{O}_{2}$ evolution and reduction [221] $\alpha-\mathrm{MnO}_{2}$ and $\mathrm{LaNiO}_{3}$ respectively with PTFE and carbon nanotubes into a paste, pressed onto Ni foam to fabricate a positive electrode for a three-cell stack. Although the stack was cycled in $0.4 \mathrm{~mol} \mathrm{dm}^{-3} \mathrm{ZnO}+6 \mathrm{~mol} \mathrm{dm}^{-3} \mathrm{KOH}$ for 100 cycles at $15 \mathrm{~mA} \mathrm{~cm} \mathrm{~cm}^{-2}$ during charge and at $25 \mathrm{~mA} \mathrm{~cm}^{-2}$ during discharge with a final energy efficiency of $c a .72 \%$, such physical catalyst mixing cannot be recommended as the oxygen reduction catalyst degrades at the charging potentials.

Mechanical regeneration of zinc particles separately from the battery is another alternative to a bifunctional positive electrode. Powerzinc Electric Inc. [222] and Electric Fuel Ltd in Israel [54] have used this type of design for electric vehicles. The zinc anodes are contained in replaceable cassettes, which are recharged by an external facility. An example of such a Znair battery was introduced by Cooper [223]. Stacks of up to 12 cells with positive electrodes of active areas between 80 and $1000 \mathrm{~cm}^{2}$ were tested. A refuel-able Zn-air stack [224], where pellet zinc electrodes and an inexpensive $\alpha-\mathrm{MnO}_{2}$ catalysed positive electrode in $\mathrm{KOH}$ electrolyte was tested in 2 and 5 cell stacks, delivering a power density of $435 \mathrm{~mW} \mathrm{~cm}^{-2}$ at a 
current density of $510 \mathrm{~mA} \mathrm{~cm}{ }^{-2}$. Smedley et al. [180] (Figure 13) constructed a regenerative Zn-air battery with a zinc electrolyser included within the system. A $18 \mathrm{~kW} 12$ cell system was demonstrated to provide $1.1 \mathrm{~kW}$ net power for 24 hours, requiring $48 \mathrm{~h}$ for regeneration. Recently, mechanically rechargeable $\mathrm{Zn}$-air batteries have been studied via electrochemical impedance spectroscopy by Mele et al.[225]. The negative electrode is fed by gravity in the form of particles of $0.4 \mathrm{~mm}$ of diameter. In a $6 \mathrm{~mol} \mathrm{dm}^{-3} \mathrm{KOH}$ solution, the cell affords a power of $36 \mathrm{~mW} \mathrm{~cm}^{-2}$ at a current density of $56 \mathrm{~mA} \mathrm{~cm}^{-2}$. Efficiency loses are due to the progressive packing of the $\mathrm{Zn}$ particles and their passivation by a $\mathrm{ZnO}$ film.

EOS Energy Storage [226] and Amendola et al. [227] have been developing an undivided Znair battery system with flowing near-neutral $\mathrm{pH}$ chloride electrolyte containing additives and buffers to aid in solubility and plating of zinc. The positive electrode contains either a $\mathrm{Mn}$ or Co-based electrocatalyst although no specific details are given. The reported product was a 1 MW/ 4 MW h DC battery at $\$ 160$ to $200 \mathrm{~kW}$ h with a system life of 5000 cycles at $75 \%$ cycle efficiency.

As part of the LIFE ZAESS project, Técnicas Reunidas, S.A. has developed a the largest pilot alkaline Zn-air RFB to date [228] to demonstrate integration of the technology with renewable energy at a grid-scale. The device comprises 20 cells arranged into 3 stacks and has a nominal energy capacity of $4 \mathrm{~kW} \mathrm{~h}$ and a nominal power of $1 \mathrm{~kW}$. In order to avoid the low stability of bifunctional electrodes, the system has been designed with two different, integrated positive electrodes, a nickel mesh for $\mathrm{O}_{2}$ evolution (charging) and a GDE for oxygen reduction (discharging). The negative electrodes are fed by a $1,000 \mathrm{dm}^{3}$ tank of zincate electrolyte. The system has a voltage of $24 \mathrm{~V}$ and maximum current of $90 \mathrm{~A}$, operating at current densities 
between 10 and $40 \mathrm{~mA} \mathrm{~cm}{ }^{-2}$. Some of the challenges experienced by the system were the cross-over of electrolyte and the effect of shunt currents on $\mathrm{Zn}$ plating in the opposite extremes of the stacks. The initial coulombic and voltage efficiencies of the battery were $82 \%$ and $34 \%$, but decreased over 2,000 cycles.

A more complex Zn-air battery coupled to propanoic acid electrosynthesis as a mean of regeneration has also been proposed [229]. The flow reactor comprises three flow channels separated by two ion exchange membranes. For the battery configuration, the conventional air electrode is used along a cadmium-coated nickel negative electrode. The positive half-cell for the electrosynthesis configuration is provided with a sintered nickel electrode for the oxidation of propanol in an alkaline media. The battery is capable of discharge at $20 \mathrm{~mA} \mathrm{~cm}^{-}$ ${ }^{2}$, achieving a coulombic efficiency of $97 \%$ and an overall energy efficiency of $59 \%$. Such a system has the disadvantage of a more complex cell design impeding the easy construction of stacks of multiple cells.

\subsection{Prospects for zinc-air redox flow batteries}

A number of design challenges must be overcome before the Zn-air RFB is developed into a commercial device. Mainly, the control of deposit morphology and shape change at the negative electrode as well as the efficiency loss due to $\mathrm{H}_{2}$. The low stability displayed so far by most bifunctional catalysts for the positive electrode reaction needs to be addressed, as it is critical for the service lifetime of the battery. A fundamental understanding of the action mechanism of electrolyte additives on the dendritic growth could lead to tailored compositions for this particular system [184]. 
Ex- and in-situ imaging techniques should be applied to the Zn-air rechargeable flow system in order to understand the systematic degradation of both electrodes. For instance Schröder et al. [230], carried out in-situ tomography of the positive electrode of a primary Zn-air battery, showing that mass transport limitations at blocked pores led to shortened lifetime. Later, the same group reported volume changes of the negative electrodes by employing in-situ tomography [231]. X-ray tomography is clearly an indispensable tool for the study of structural changes at the electrodes during charge and discharge. Conversely, a simple one dimensional model of a secondary Zn-air battery developed by Deiss et al. [232] showed that pore plugging was not the main failure mechanism, but rather the depletion of $\mathrm{OH}^{-}$ions in the negative electrolyte at high current density. A well-considered experimental design is hence important to avoid discrepancies in the results. A combination of these techniques could provide valuable insights into cycling effects on the structure and composition of the oxygen electrodes.

\section{Zinc-nickel redox flow batteries}

The Zn-Ni RFB, also known as a 'flow assisted battery', is receiving increasing attention as utility scale storage becomes central to the integration of renewable energy sources. Zn-Ni static batteries were invented by Edison in 1901 [47] and were further developed by Drum in Ireland for railway use in the 1930s [233]. In the 1970s, secondary Zn-Ni batteries became commercial and have since been used in portable power tools and several types of vehicles [233], offering an alternative to Ni-Cd batteries. Flow-assisted $\mathrm{Zn}-\mathrm{Ni}$ batteries were introduced in 2007 with the aim of providing utility scale energy storage [27, 234-238]. 
The $\mathrm{Zn}-\mathrm{Ni} \mathrm{RFB}$ is an undivided, alkaline system using either $\mathrm{NaOH}$ or $\mathrm{KOH}$ solutions as the common electrolyte. In this battery, the negative electrode process in reaction (2) is accompanied by the positive electrode reaction:

$$
\mathrm{Ni}(\mathrm{OH})_{2}+\mathrm{OH}^{-}-\mathrm{e}^{-} \rightleftarrows \mathrm{NiO}(\mathrm{OH})+\mathrm{H}_{2} \mathrm{O} \quad E^{0}=0.49 \mathrm{~V} \text { vs. SHE }
$$

giving an overall cell reaction

$$
\mathrm{Zn}(\mathrm{OH})_{4}{ }^{2-}+2 \mathrm{Ni}(\mathrm{OH})_{2} \underset{\text { Discharge }}{\stackrel{\text { charge }}{\rightleftarrows}} \mathrm{Zn}+2 \mathrm{NiO}(\mathrm{OH})+2 \mathrm{OH}^{-}+2 \mathrm{H}_{2} \mathrm{O} \quad E_{\text {cell }}^{0}=1.73 \mathrm{~V}
$$

The open-circuit cell potential of laboratory Zn-Ni RFBs is $1.6 \mathrm{~V}$. In general, these batteries display a coulombic efficiency of $95 \%$, a voltage efficiency of $88 \%$, and an energy efficiency over $80 \%$ [27].

The Zn-Ni RFB has several advantages. For instance, the rapid kinetics of the redox couple provides a fast charge/discharge capability. The energy density of the system is large due to the relatively high standard cell potential of $1.73 \mathrm{~V}$. A long cycle life is achievable by the stabilisation of the $\mathrm{Zn}$ electrode in the alkaline electrolyte. Additionally, the $\mathrm{Zn}-\mathrm{Ni}$ system promises to be cost competitive as a result of using relatively cheap and abundant metals with the elimination of the requirement for separators, which can be expensive, limited lifetime and fragile, complicating cell design. 
Furthermore, the $\mathrm{Zn}-\mathrm{Ni}$ system is environmentally friendly due to the use of low-toxicity zinc and nickel active materials. Spanos et al. [239] have assessed the environmental impact of the Zn-Ni RFB compared with static electrolyte Zn-Mn and lead acid systems by conducting life cycle analysis studies. The battery used for this study utilised a $\mathrm{Cu}$ negative electrode substrate sintered Ni positive electrode and a $\mathrm{NaOH}$ electrolyte. Of the three systems investigated, the $\mathrm{Zn}-\mathrm{Ni}$ battery was found to have the lowest environmental impact, with an energy demand of 1.7-2.3 $\mathrm{MJ} \mathrm{W}^{-1} \mathrm{~h}^{-1}$ compared with 2.2-2.8 $\mathrm{MJ} \mathrm{W}^{-1} \mathrm{~h}^{-1}$ for lead acid batteries and 10.6-14.0 MJ $\mathrm{W}^{-1} \mathrm{~h}^{-1}$ for $\mathrm{Zn}-\mathrm{Mn}$ batteries. The global warming impact of the $\mathrm{Zn}-\mathrm{Ni}$ RFB was also considered to be the lowest, at $0.11-0.14 \mathrm{~kg} \mathrm{CO}_{2}$ equivalent per $\mathrm{W} \mathrm{h}$.

There are, however, challenges associated with the Zn-Ni system. As with other zinc negative batteries, the morphology of the zinc deposition at the negative electrode can be problematic. Shape changes can occur due to inconsistent distribution of zinc deposition over the surface area of the electrode, while $\mathrm{H}_{2}$ and $\mathrm{O}_{2}$ gas can evolve during charging at the zinc and nickel electrodes, respectively. In addition, the capacity of the $\mathrm{Zn}-\mathrm{Ni}$ cell is limited by the amount of active material at the surface of the positive nickel electrode. Therefore, a larger surface area of nickel electrode leads to a higher cell charge capacity.

\subsection{The zinc negative electrode}

The negative electrode in the alkaline $\mathrm{Zn}-\mathrm{Ni} \mathrm{RFB}$ is analogous to that in the $\mathrm{Zn}$-air system. As described in section 4.1, this electrode can suffer from $\mathrm{H}_{2}$ evolution, dendritic growths and $\mathrm{H}_{2}$ evolution. Bass et al. [240] have summarized a number of strategies to overcome these problems, such as alternative separators and cell design, electrolyte and electrode additives as well as the implementation of pulse charging and electrode vibration. 
Electrolyte additives are the most common strategy to obtain smooth zinc deposits and inhibiting $\mathrm{H}_{2}$ evolution. Additives can produce compact deposits by enabling the complete dissolution of the zinc deposit during discharge, stopping the build/up of material and the depletion of zinc ion in the electrolyte, which lead to electrode overpotentials. Research on electroplating and primary batteries has reported a large number of electrolyte additives, as shown in Table 5. They include organics, acids, polymers and metal ions. Some of these compounds can be incorporated into solid electrodes [241].

Some of the most effective additives in zinc electrodeposition are heavy metals such as mercury, cadmium, lead or oxides of these $[233,240]$. These additives can be present in the solution or be alloyed in zinc electrodes in order to supress dendritic growths and inhibit $\mathrm{H}_{2}$ evolution. Nevertheless, environmental and health concerns have imposed restrictions to the use of these metals, resulting in a requirement for non-toxic and cost effective replacements, usually organics.

Alternatives to heavy metals include bismuth, calcium, magnesium, indium, tin and tungsten [233, 240], as well as fluorides, phosphates and borates [249]. Calcium is one of the most promising due to the formation of insoluble calcium zincate, $\mathrm{Ca}(\mathrm{OH})_{2} \cdot 2 \mathrm{Zn}(\mathrm{OH})_{2} \cdot 2 \mathrm{H}_{2} \mathrm{O}$. By decreasing the migration of zincates from the electrode into the electrolyte, shape problems can be ameliorated [240], since zinc can migrate across the soluble zincates layer. Jain et al. [242] have confirmed these effects of calcium-zincate in a Zn-Ni RFB, noting that the utilization of zinc increased and that $25 \%$ w.t. calcium affords better results. The same group have reported that a $\mathrm{KOH}-\mathrm{KF}-\mathrm{K}_{2} \mathrm{CO}_{3}$ electrolyte also suppressed electrode shape change, preventing short-circuiting by dendrite for 575 cycles in $\mathrm{Zn}-\mathrm{Ni}$ cell [250]. 
The combination of more than one additive can significantly improve the electrodeposition of zinc and extend the life expectance of batteries. For instance, Wen et al. [171] have shown that a combination of an inorganic and an organic additive can promote the formation of smooth deposits instead of spongy ones, as shown in Figure 14. The efficiency of the battery was also improved. Their electrolyte contained a mixture of $1.0 \times 10^{-4} \mathrm{~mol} \mathrm{dm}^{-3} \mathrm{~Pb}^{2+}$ and 5.0 $\times 10^{-5} \mathrm{~mol} \mathrm{dm}^{-3} \mathrm{Bu}_{4} \mathrm{~N}^{+}$. Although lead is present in small concentrations, alternatives are preferred due to environmental considerations.

Organic additives such as polytetrafluoroethylene (PTFE), polyvinyl alcohol, polyethylene glycol, polyethylenimine, quaternary ammonium salts, and cellulose have received consideration [240, 243]. These additives are adsorbed selectively at sites undergoing fast electrodeposition, which results in compact deposits with finer grain sizes. Additives can be incorporated within the electrode material itself for instance, Müller et al. [175] have prepared pasted electrodes for the $\mathrm{Zn}$-air battery, containing $10 \%$ w.t. cellulose, $4 \% \mathrm{PTFE}$ and $2 \% \mathrm{PbO}$. Similar cellulose additives could prove advantageous to the $\mathrm{Zn}-\mathrm{Ni}$ system. Such cellulose additives promote deposit nucleation and produce a hydrophilic surface, which results in significant increments in electrode stability and power capacity.

The effect of adding iron to the zinc electrode substrate was investigated by Kwak et al. in a stirred batch cell [251]. They compared a $\mathrm{ZnO}$ electrode consisting of nano scale rods $20 \mathrm{~nm}$ $\times 40 \mathrm{~nm}$ in size with a $\mathrm{ZnO} / \mathrm{Fe}$ electrode using the same $\mathrm{ZnO}$ rods and a $1 \%$ addition of spherical Fe particles about $15 \mathrm{~nm}$ in diameter. It is reported that the $\mathrm{ZnO} / \mathrm{Fe}$ battery displayed an improved capacity of $230 \mathrm{~mA} \mathrm{~h} \mathrm{~g}$-1 over 40 cycles at $30 \mathrm{~mA} \mathrm{~cm}^{-2}$. The addition of iron also suppressed dendritic formation due to the decreased direct contact between the deposited zinc crystals in the presence of $\mathrm{Fe}^{2+}$. 
Controlled electrolyte flow in Zn-Ni RFBs, is also an effective approach to suppressing dendrite growth and shape change of the zinc electrode. For instance, by combining a low current density of $20 \mathrm{~mA} \mathrm{~cm}^{-2}$ and a mean linear electrolyte flow rate of $15 \mathrm{~cm} \mathrm{~s}^{-1}$, Ito et al. [178] were able to sustain the operation of their laboratory cell for over 1,500 cycles. Further work [234], showed that higher mass transport rates were also beneficial to the efficiency of the device, as they reduced gas evolution. The same authors have investigated the variation in zinc morphology in terms of a current density ratio, defined as the ratio of effective current density to limiting current density [252]. The limiting current density is found by equation (11), where $n$ is the electron stoichiometry, $F$ is the Faraday constant, $D$ is the diffusion coefficient of zinc ions, $C_{0}$ is the bulk concentration, $d_{e}$ is the hydraulic diameter and $S h$ is the Sherwood number. They found that a current density ratio below 0.4 produced mossy and porous deposits, while a ratio above 0.9 produced compact, crystalline deposits. Between 0.4 and 0.9 , the deposits obtained were a mixture of these morphologies.

$$
i_{\text {lim }}=\frac{n F D C_{o}}{d_{e}} S h
$$

The effect of various negative electrode substrates on zinc deposition morphology and stability was studied by Wei et al. [253]. The substrates investigated were silver, bismuth, copper, iron, nickel and antimony and the corrosion behaviour of the resultant zinc depositions

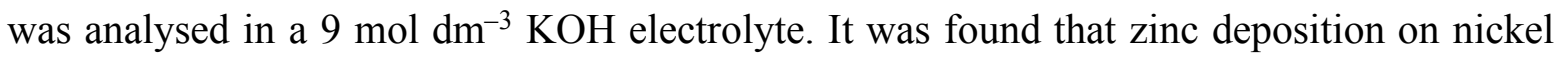
substrates tended to be mossy and porous, and prone to corrosion due to increased $\mathrm{H}_{2}$ evolution. The deposition of zinc on bismuth, copper and tin substrates was of a compact crystalline morphology. However, the antimony substrate was prone to corrosion in alkaline 
media over extended periods of time. It was suggested that bismuth and copper substrates are most suitable due to the resistance to corrosion and compact zinc morphology.

A way to prevent short circuiting of the cell due to dendritic growth and shape change consists of performing periodic reconditioning cycles [57]. During these cycles, the zinc deposits in the negative electrodes are completely removed by discharging the cell at low current densities (to minimize $\mathrm{H}_{2}$ evolution) until the cell potential reaches $0 \mathrm{~V}$. It is claimed that a Zn-Ni cell endured more than 2,000 charge/discharge cycles free of short-circuiting by implementing this method. Suitable electrode materials, i.e., not corroding or passivating during the stripping cycles, must be employed.

\subsection{The nickel positive electrode}

This electrode reaction benefits from decades of research on Ni-Cd batteries [42]. The technology for its manufacture can be readily transferred. The mass of active material in the electrode and its surface area determine the capacity of the Zn-Ni battery. Two methods are usually applied to the commercial manufacture of nickel electrodes: a) sintered nickel and b) pasted nickel. The latter have higher porosity, lower density and lower cost but also shorter life expectancies due to limited use of the active material and swelling. As a result, the more expensive sintered type is usually preferred. These electrodes are prepared by subjecting carbonyl nickel powered to a thermal treatment, which produces a porous structure that can be later impregnated with nickel hydroxide.

The group of Zhang et al. [238, 254-259] has applied sintered nickel electrodes to undivided Zn-Ni RFBs. They have shown that enhanced performance can be achieved by implementing serpentine flow channels in the positive electrode, which decreases mass transport limitations. 
This design has proved reliable form 70 charge/discharge cycles at $80 \mathrm{~mA} \mathrm{~cm}^{-2}$ [255], during which the overall energy efficiency was $75 \%$. Later, the same group demonstrated the feasibility of $\mathrm{Zn}$ electrodeposition on a 3-D porous nickel foam electrode [238]. This type of electrode material limits the operational negative electrode current density to values just over $50 \mathrm{~mA} \mathrm{~cm}{ }^{-2}$. Below this value, uniform $\mathrm{Zn}$ deposits were observed on the substrate but, as the current density increases, spongy and dendritic deposits are formed instead.

Nanostructured materials have been applied to increase the capacity of the Zn-Ni system by extending the surface area of the nickel electrode. Zhang et al. [258] have filed a patent for the implementation of double bilayer nanotubes as positive electrode material. The nanotubes comprised a zinc oxide inner structure covered by a nickel hydroxide layer. The energy density of the battery was claimed to be enhanced by approximately $10 \%$. He et al. [260] have recently studied the use of a positive electrode consisting of nickel tubes with a wall thickness of $0.6 \mathrm{~mm}$ and an inner diameter of $5 \mathrm{~mm}$. This was found the have a specific capacity of 35.7 $\mathrm{mA} \mathrm{h} \mathrm{cm} \mathrm{c}^{-2}$ and retained $82 \%$ of this capacity after 480 cycles. The reported coulombic and energy efficiencies were quite high, at $96.0 \%$ and $83.8 \%$ respectively.

\subsection{Cell developments}

The membrane-free Zn-Ni RFB system was first proposed by a Chinese group in 2007 [27]. A concept cell was presented, with a cell potential over $1.6 \mathrm{~V}$ and an overall efficiency over 85\%. This cell design was later improved by employing cadmium electroplated nickel as negative electrode [236], which resulted in energy efficiencies of $88 \%$ over 220 cycles. A second Chinese group patented nanostructured materials for the positive electrode (see section 5,2) [258] and subsequently developed a serpentine flow-field Zn-Ni RFB with a power density of $83 \mathrm{~W} \mathrm{~kg}^{-1}$, which sustained an energy efficiency of $80 \%$ over 200 charge/discharge cycles [254, 255]. The effect of temperature over this cell was also studied [257], showing 
that moderately high temperatures were beneficial for its performance. For example, at a current density of $80 \mathrm{~mA} \mathrm{~cm}^{-2}$, the overall energy efficiency increased from $53.0 \%$ at $0{ }^{\circ} \mathrm{C}$ to $70.1 \%$ at $40{ }^{\circ} \mathrm{C}$. More recently, Yao et al. [261] have studied the electrode potential of this battery, while Wang [262] proposed an alternative Zn-Ni flow cell where the cathode is a $\mathrm{Ni}(\mathrm{OH})_{2}$ electrode coated with a $\mathrm{O}_{2}$ reduction catalyst.

Developments at City University of New York were reported in 2011 [178]. This collaboration described the operation of a $3.7 \mathrm{~A}$ h cell over 1,500 cycles, during which coulombic and energy efficiencies over of $90 \%$ and $80 \%$, respectively were achieved. This long operational life time was enabled by carrying out a reconditioning step every 15 cycles. This technology was up-scaled into a $100 \mathrm{~W}$ h prismatic cell demonstrated over 200 cycles [57] then later with a $25 \mathrm{~kW}$ h battery [237]. As shown in Figure 15, this device comprised thirty $555 \mathrm{~A} \mathrm{~h} / 833 \mathrm{~W}$ h cells and operated successfully over 3,300 cycles yielding an average energy efficiency $>80 \%$. However, the positive electrode passivated at overpotentials of $100 \mathrm{mV}$ above opencircuit potential and the interelectrode gap was obstructed by zinc particulate formation, causing cathode degradation. The absence of an external electrolyte tank eliminated the risk of leakage and reduced pumping energy losses associated with pressure drops in connecting pipework. This helps to facilitate a consistent electrolyte flow regime within the cell. Turney et al. [237] reported that $4 \%$ of the cell energy was consumed to power the built-in pump, which they considered a small proportion.

In addition to the practical work discussed above, Lin et al. [263] and Li et al. [264] have developed models of the Zn-Ni RFB system with a view to optimising efficiency. While the first model focuses purely on the cell itself, the second includes both the cell and the effect of electrolyte flow rate and energy consumed by the pump. They conclude that to optimise 
efficiency the flow rate should be matched to the operating current of the system, with higher flow rates being applied for higher operating currents.

\subsection{Prospects for zinc-nickel redox flow batteries}

Due to the potential advantages of the $\mathrm{Zn}-\mathrm{Ni} \mathrm{RFB}$ in terms of performance, cost and environmental impact, it can be expected that this system will be commercially developed. As detailed below, pilot utility scale Zn-Ni RFBs are being currently developed by the Chinese company Zhangjiagang Smart Grid Fanghua Electrical Energy Storage Research Institute Co. Ltd. and the City University of New York. Critical aspects to achieve reliable devices include the improvement of energy density and electrolyte conductivity, materials for the positive electrode as well as the usual control of zinc deposit shape and morphology. Furthermore, engineering aspects have not been well considered in several reported $\mathrm{Zn}-\mathrm{Ni}$ flow cells. If these issues can be overcome using the methods previously discussed, it seems likely that a Zn-Ni RFB can be developed with energy efficiencies well in excess of $80 \%$ over 3,000 or more cycles.

\section{Other zinc-based redox flow batteries}

A number of Zn-based RFBs have been developed, constituting alternatives to the promising medium sized $\mathrm{Zn}-\mathrm{Br}_{2}$, $\mathrm{Zn}-\mathrm{Ce}$ and $\mathrm{Zn}$-air batteries, which have been compared in a recent book chapter [265]. In fact, most Zn-based RFBs can be traced back to the $\mathrm{Zn}^{-\mathrm{Cl}_{2}} \mathrm{RFB}$ of 1974 , followed by the $\mathrm{Zn}$-ferricyanide system initially developed in parallel to the $\mathrm{Zn}-\mathrm{Br}_{2}$ chemistry (see Figure 1). In recent years, several RFBs have been proposed/reintroduced due to renewed interest in renewable energy storage, including those involving microparticle suspensions, polymeric active species and concentration cells. These systems are described below. 
The $\mathrm{Zn}-\mathrm{Cl}_{2} \mathrm{RFB}$ received consideration in the 70s and 80 s following its development by Gulf \& Western Industries [50]. Research also took place in Japan by Furukawa Electric Co. [66]. Since the management of gaseous $\mathrm{Cl}_{2}$ generated at the positive electrodes would have been difficult, this technology was based on the storage of $\mathrm{Cl}_{2}$ in the form of hydrate in a refrigerated system [74]. The electrode kinetics and mass transport properties of graphite positive electrodes were studied [266] and porous graphite electrodes were simulated [267]. The battery was limited by the mass transport overpotential at the zinc planar electrodes [24] and by the self-discharge corrosion of the zinc deposits [268]. Porous zinc electrodes made by replaceable rods were proposed to ease mass transport [269], while the morphology and stability of zinc was improved by the addition of $\mathrm{Pb}^{2+}[270]$ and $\mathrm{Bi}^{3+}[271]$ ions into the electrolyte. The Gulf project was considered successful after testing $10 \mathrm{~kW} \mathrm{~h}$ modules as part of a $100 \mathrm{~kW} \mathrm{~h}$ energy storage facility [50]. At a current density of $30 \mathrm{~mA} \mathrm{~cm}{ }^{-2}$, the system showed an energy efficiency of $68 \%$. The $80 \mathrm{~kW}$ h Furukawa project reported a similar overall efficiency of $65 \%$ [66] but the complexity of the system has discouraged further development.

Another early RFB based on abundant inexpensive reagents is the $\mathrm{Zn}$-ferricyanide system introduced by Lockheed [29]. The unit cell gives a potential of $1.61 \mathrm{~V}$ and relies on graphite bipolar electrodes coated with cadmium on the negative side and nickel on the positive side. Alternatively, nickel-coated carbon felt could be used as the positive electrode. Zinc deposition at the negative electrode is coupled to the ferrocyanide/ferricyanide redox couple at the positive electrode:

$$
\mathrm{Fe}(\mathrm{CN}) 6^{3-}+\mathrm{e}^{-} \rightleftarrows \mathrm{Fe}(\mathrm{CN})_{6}{ }^{4-}
$$


Its limitations included $\mathrm{Zn}$ corrosion and the requirement of management of solids due to the $\mathrm{ZnO}$ slurry generated during discharge and the presence of ferri- and ferrocyanide crystals in the positive electrolyte. Cell balance was achieved by directing $\mathrm{H}_{2}$ evolved at the $\mathrm{Zn}$ electrode to the positive electrolyte in order to reduce ferricyanide. Mass transfer at the zinc electrodes and its current distribution were studied [272] and the cycling of the battery was simulated [273]. Although the system yielded an energy efficiency of $75 \%$ and low-cost sulfonated polystyrene and polysulfone membranes were especially developed [274], the cost of commercial membranes and the difficult management of solids stopped this development. Furthermore, the speciation of ferricyanide in $\mathrm{NaOH}$ solutions and its effects on the electrochemistry at nickel-coated electrodes appear to have been ignored at the time. However, due to its relative low cost the $\mathrm{Zn}$-ferricyanide alkaline RFB was commercially reintroduced in 2013 by ViZn Energy Inc. (USA) claiming future development of utility-scale installations [275]. Technological improvements on the Lockheed battery have not been disclosed. Studies on the long-term stability of the photosensitive ferricyanide under closed battery conditions have not been reported.

A Zn-Fe RFB with a thermodynamic cell potential of $1.53 \mathrm{~V}$ has been developed [276]. This battery differs from the Zn-ferricyanide as its employs an iron chloride in an acetate buffer solution as electrolyte in order to prevent the hydrolysis of $\mathrm{Fe}^{3+}$ ions. An energy efficiency of $71 \%$ was reported and the system presented as a lower cost alternative to the $\mathrm{Zn}$-Ce RFB. A similar Zn-Fe RFB comprises Zn electrode reaction in an alkaline electrolyte, the Fe electrode reaction in an acidic chloride reaction and an intermediate 'middle electrolyte' [277]. The intermediate flow compartment with $\mathrm{NaCl}$ requiring two membranes to separate the electrodes would be difficult to implement in practice, not to mention higher potential losses. Another $\mathrm{Zn}$-Fe cell employing a single acidic chloride solution containing $\mathrm{NH}_{4}{ }^{+}$ions has also 
been proposed [30]. This system offers the possibility of operating without membrane or with inexpensive microporous separators. The effect of $\mathrm{Zn} / \mathrm{Fe}$ ion ratio on the electrodeposition reactions at both electrodes was studied. Over 130 charge/discharge cycles, a unit cell presented coulombic and voltage efficiencies of $85 \%$ and $80 \%$, respectively, and an energy efficiency of $68 \%$.

Divided Zn-polyiodide RFBs with graphite felt electrodes have been proposed based on the zinc negative electrode reaction and the triodide/iodide redox couple at the positive electrode during discharge [31]:

$$
\mathrm{I}_{3}^{-}+2 \mathrm{e}^{-} \rightleftarrows 3 \mathrm{I}^{-} \quad E^{o}=0.536 \mathrm{~V} v s . \text { SHE }
$$

Voltammograms for these reactions in a near-neutral $5.0 \mathrm{~mol} \mathrm{dm}^{-3}$ zinc iodide electrolyte are shown in Figure 16a). This chemistry could enable the implementation of low-cost microporous separators. Due to the association of iodine ions, the cell potential decreases from $1.26 \mathrm{~V}$ at $0.5 \mathrm{~mol} \mathrm{dm}^{-3}$, to $0.96 \mathrm{~V}$ at $5 \mathrm{~mol} \mathrm{dm}^{-3}$. NMR studies suggest that the addition of ethanol to the electrolyte should prevent thermal precipitation over a wide range of temperatures. The authors claim an energy density of $167 \mathrm{~W} \mathrm{~h} \mathrm{dm}^{-3}$. Figure $16 \mathrm{~b}$ ) shows the efficiency of a single cell operating at a current density of $10 \mathrm{~mA} \mathrm{~cm}{ }^{-2}$. A mitigation of dendritic grown by the addition of ethanol was observed. In view of the limited availability of free iodine ions in a concentrated electrolyte, another group [278] has proposed the addition of bromide ions in order to form a stable complex, which significantly increases the energy density of this RFB. 
Variants of Zn-based RFBs are reported in the current literature. For instance, a zincvanadium RFB based on methanesulfonic acid solutions containing up to $3 \mathrm{~mol} \mathrm{\textrm {dm } ^ { - 3 }}$ $\mathrm{V}(\mathrm{IV}) / \mathrm{V}(\mathrm{V})$ has been proposed [26]. The device provides a discharge cell potential of $1.7 \mathrm{~V}$, yielding coulombic and voltage efficiencies of $96 \%$ and $67 \%$, respectively, during short-term testing. An undivided $\mathrm{Zn}-\mathrm{PbO}_{2} \mathrm{RFB}$ with phase change on both electrodes in a sulfuric acid electrolyte has been also studied [102]. Electrolyte composition, zinc deposit morphology and additives were reported. The cell potential of this battery is relatively high, close to $2.4 \mathrm{~V}$. At a discharge current density of $150 \mathrm{~mA} \mathrm{~cm}^{-2}$ the charge efficiency was $c a .87 \%$ [279].

The feasibility of an unusual $\mathrm{Zn}-\mathrm{Ag}$ concentration cell using low-cost microporous separators has been studied preliminary [280]. This battery is driven by the different concentration of $\mathrm{ZnCl}_{2}$ in two solutions as a result of a distillation step. With $\mathrm{Zn}$ and $\mathrm{Ag}$ electrodes, a modest potential of up to ca. $1.04 \mathrm{~V}$ can be achieved. Another new RFB concept can be found in a $\mathrm{Zn}-\mathrm{Ag}$ doped polyaniline (Pani) suspension RFB [58]. As shown in Figure 17, a single $\mathrm{ZnCl}_{2}$ electrolyte flows into the positive half-cell, where it partially diverts into the negative halfcell, from there the solution goes back to the reservoir. The microparticles cannot pass through the microporous separator, remaining in the positive side. In this way, an average cell potential of about $0.7 \mathrm{~V}$ can be obtained during a $150 \mathrm{~mA} \mathrm{~cm}-2$ discharge. The degradation of the positive graphite electrode by the oxidation polyaniline and the low achieved cell potential are the main disadvantages of this system.

Organic active species are being increasingly considered for RFBs and $\mathrm{Zn}$ systems are no exception. A Zn-polymer RFB has been demonstrated using 2,2,6,6-tetramethylpiperidinyl$\mathrm{N}$-oxyl (TEMPO) as the active redox species in the positive electrode [281-283]. The positive active species resides in the electrolyte in the form of poly(TEMPO methacrylate) micelles. 
Hazardous zinc perchlorate is used as both positive and negative support electrolyte, while the relatively large size of the micelles prevents their transport through the membrane. At the very low operational current density of $1.5 \mathrm{~mA} \mathrm{~cm}^{-2}$ the device produces a cell potential of ca. $2 \mathrm{~V}$ and a current efficiency of $98 \%$. This and similar polymer-based RFBs have not yet demonstrated cycling stability under realistic operational conditions.

\section{New trends on zinc-based redox flow batteries}

\subsection{Zinc polymer electrodes}

In addition to the carbon and metallic substrates previously discussed, the negative electrode can also consist of a zinc polymer composite. Such electrodes can prevent dendritic zinc depositions and reduce both electrode shape change and self-discharge rate due to zinc dissolution, thus improving electrode cycle life. One example of this is the plastic bonded electrode, in which zinc oxide powder is combined with PTFE using organic solvent in a calendaring process. The PTFE is fibrillated to form a nanoscale, three-dimensional electrode matrix. The locking of the active materials into this structure mitigates the problems of electrode shape change and dendritic zinc electrodeposition morphology [42].

An early comparison of the cycling performance of porous zinc electrodes in the absence and presence of different polymers at varying concentrations was carried out by Hampson and McNeil [284]. In this case, the electrodes were pasted $\mathrm{Zn} / \mathrm{ZnO}$ with concentrations of various polymers up to $50 \%$, which were then painted and pressed onto copper gauze substrates. The resultant electrodes were cycled in a $7 \mathrm{~mol} \mathrm{dm}^{-3} \mathrm{KOH}$ solution. It was found that polystyrene and polyvinylchloride addition could not improve cycle life at any concentration and polyvinyl acetate, polyisoprene and polymethyl methacrylate produced only small improvements at concentrations of $10 \%$ or less. This reduction in performance was attributed 
to the blocking of electrode pores by either $\mathrm{ZnO} / \mathrm{Zn}(\mathrm{OH})$ discharge reaction products or hydrogen gas, with the latter not being expelled from the electrode structure due to the low wettability of the polymeric materials. Polycarbonate, however, showed significant augmentation of electrode cycle life at concentrations of up to $20 \%$, with the cycle life being almost tripled compared to plain zinc electrodes at concentrations of $10 \%$ or less. This is due to the high permeability of the polycarbonate electrodes, which allowed full utilisation of the deposited zinc during discharge and prevented the blocking of electrode pores.

Sun et al. [69] investigated high density polyethylene (HDPE)-carbon composite electrodes with carbon black or MWCNT to provide conductivity, in volume fractions of $19 \%$ and $15 \%$ respectively. Despite the lower concentration of MWCNT it was found that the bulk conductivity of this electrode was four times that of the carbon black electrode, due to the higher conductivity of MWCNT compared with carbon black particles. However, the surface conductivity of the MWCNT electrode suffered significant variations due to the heterogeneous nanotube dispersions in the composite. This results in varying potentials across the electrode surface, and causes the uneven deposition of zinc during charging. The development of methods to provide a homogenous distribution of nanotubes in this type of electrode would overcome this issue.

Ghazvini et al. [285] have reported on a zinc polymer electrode containing polystyrene spheres $600 \mathrm{~nm}$ in diameter. The electrode was produced by deposition of the polystyrene spheres onto a polished brass substrate to form a hexagonal closed packed structure. Zinc metal is then electrodeposited onto the substrate, filling the voids between the polystyrene spheres. By forcing the zinc to adhere to the structure defined by the polystyrene spheres, 
dendritic growth is avoided. However, the reported coulombic efficiency is low at $c a .70 \%$, and the deposited zinc was often insufficiently adherent to the substrate.

\subsection{Ionic liquid electrolytes}

Ionic liquids, or molten salts, have a number of potential advantages as electrolytes over traditional aqueous solutions due to their low volatility and wide range of electrochemical stability (up to $6 \mathrm{~V}$ ) [286]. These advantages include the prevention of zinc dendrite formation, $\mathrm{H}_{2}$ evolution and self-discharge due to the solubility of zinc. In addition, ionic liquids can overcome the problems of electrolyte evaporation and $\mathrm{CO}_{2}$ absorption associated with open systems utilising aqueous solutions, such as Zn-air batteries. However, ionic liquids suffer from relatively low conductivity, being an order of magnitude or lower than in aqueous electrolytes. Many ionic liquids have sufficiently low melting points to be liquid at room temperature making them feasible electrolytes for battery systems operating at ambient temperature. Such substances are termed room temperature ionic liquids (RTILs) and are most often based on quaternary ammonium salts or cyclic amines, although RTILs based on sulfonium and phosphonium cations also exist [286].

Recently, several papers have proposed the use of ionic liquid-based electrolytes in various zinc negative battery systems, mainly focusing on the electrodeposition morphology of zinc from ionic liquids. Keist et al. [287], for example, investigated the electrodeposition of zinc from a 1-butyl-3-methyl-imidazolium trifluoromethanesulfonate electrolyte with 0.34 mol $\mathrm{dm}^{-3}$ zinc trifluoromethanesulfonate, while Liu et al. [288] conducted a similar study using a 1-ethyl-3-methylimidazolium trifluoromethylsulfonate electrolyte with $0.1 \mathrm{~mol} \mathrm{\textrm {dm } ^ { - 3 }}$ $\mathrm{Zn}(\mathrm{TfO})_{2}$ and $0.015 \mathrm{~mol} \mathrm{dm}^{-3} \mathrm{Ni}(\mathrm{TfO})_{2}$. Both groups reported a compact zinc deposition morphology comprising of co-aligned hexagonal platelets at current efficiencies of around 
99\%. Liu et al. [289] also reported on the electrodeposition of zinc from a 1methylimidazolium trifluoromethylsulfonate electrolyte. The zinc morphology was found to be porous and mossy in the purely ionic liquid electrolyte. However, the addition of $30 \%$ w.t. water to the electrolyte resulted in the deposition morphology being more compact, with hexagonal platelets similar to those previously reported.

Recent work has also been undertaken on polymer gel electrolytes (PGEs) based on ionic liquids. Xu et al. [290] assessed the suitability of PGEs based on 1-ethyl-3methylimidazolium trifluoromethanesulfonate with zinc triflate, using poly(vinylidene fluoride co-hexafluoropropylene) to form a polymer matrix, as electrolytes for zinc based battery systems. Although the zinc deposition morphology was not investigated in this study, the produced PGEs were shown to be conductive to zinc ions, and demonstrated thermal stability between -50 and $100{ }^{\circ} \mathrm{C}$, with a sufficiently wide electrochemical window of $2.8 \mathrm{~V}$ vs. $\mathrm{Zn} / \mathrm{Zn}^{2+}$. Current efficiencies in excess of $90 \%$ were reported. Liu et al. [291] studied the performance of a PGE using 1-butyl-1-methylpyrrolidinium trifluoromethylsulfonate and $0.2 \mathrm{M} \mathrm{Zn}(\mathrm{TfO})_{2}$, with a polymer matrix of poly(vinylidene fluoride-co-hexafluoropropylene). The morphology of zinc deposits from this electrolyte were found to be smooth and compact, and stable current efficiencies of over $80 \%$ were achieved. Although ionic liquid electrolytes are at a relatively early stage of development, their potential for use in zinc-based battery systems has been demonstrated. However, many ionic liquids are considerably more expensive than traditional aqueous solutions and some are sensitive to atmospheric oxygen or water. 


\section{Conclusions}

Zn-based RFBs offer many opportunities for development. They provide high cell potentials using an abundant, low cost negative electrode material. In general, the phase change that takes place during charge can create problems during scale-up but it is expected that tailored cell design and control of deposit morphology by electrolyte additives will extend reliability and cycling life. The mature $\mathrm{Zn}-\mathrm{Br}_{2}$ system has proven the reliability of this concept, becoming a fully demonstrated commercial device with increasing implementation. Other systems such as Zn-Ce and Zn-Ni are in earlier stages of development. Zn-Ce cells can yield a high cell potential, but cost-effective positive electrodes are yet to be implemented. Nondivided Zn-Ni RFBs appear to have several advantages and are currently developed by several companies due to its potential scalability, although several research needs have been identified. Zn-air batteries offer the challenge of attaining high energy density by harvesting atmospheric $\mathrm{O}_{2}$ and progress need to be made on finding cost-effective, more efficient catalysts, but has faced several scale-up complications. A number of new battery concepts have been recently proposed, but attention should be given to technological practicality, safety, capital and running costs, simplicity and lifetime.

Some general features can be highlighted regarding Zn negative RFB studies:

1. The benefits of a very negative electrode potential and limitations due to shape changes, shunt currents and corrosion of the zinc electrode in secondary flow cells for energy storage, have been highlighted.

2. Diverse cell chemistry is evidenced by examples of acid (Zn-Ce) and alkaline (Zn-air, ZnNi) zinc electrolytes. 
3. Cells divided by an ion exchange membrane ( $\mathrm{Zn}-\mathrm{Ce})$, microporous separators $\left(\mathrm{Zn}-\mathrm{Br}_{2}\right)$ and undivided, single flow circuit (Zn-Ni) cells are illustrated.

4. The positive electrode reaction can involve a bifunctional oxygen gas diffusion electrode ( $\mathrm{Zn}$-air cell), a redox reaction if a soluble species at an inert electrode ( $\mathrm{Zn}-\mathrm{Ce}$ cell) or formation/disappearance of surface oxides on the electrodes ( $\mathrm{Zn}-\mathrm{Ni}$ cell).

5. Performance and lifetime limitations arise due to corrosion of zinc deposits (particularly in acid media), leading to the need for suitable electrolyte additives to moderate corrosion rates.

6. Abundant relevant experience can be found in work related to $\mathrm{Zn}$-based static batteries, industrial $\mathrm{Zn}$ plating and recovery, engineering of electrochemical reactors and some outdated RFB systems.

\section{Topics requiring further research}

The continued development of zinc negative electrode RFBs and their successful commercial implementation requires critical attention to several aspects.

1. Cell engineering, including computational modelling of performance and characterisation of reaction environment to improve performance, lifetime and acceptability on a larger, e.g., grid scale.

2. Experience of scale-up and process operation on the large-scale, following the fundamental principles of electrochemical engineering.

3. Improved, low-cost separators/membranes and cell manufacture for higher performance and longevity with reduced capital and running costs. 
4. Non-toxic electrolyte additives to moderate zinc deposition, stripping and open-circuit corrosion, in both acidic and alkaline media.

5. Porous, 3-D electrodes with tailored uniform potential distribution to improve energy density while maintain an efficient reaction engineering environment.

\section{Acknowledgements}

LFA acknowledges the support provided by CONACYT (314057) and the Research Institute for Industry of the University of Southampton. The authors are grateful to Redflow for ceding a photograph of a $\mathrm{Zn}-\mathrm{Br}$ battery. Permission has been obtained for reproducing all copyrighted material.

\section{Declaration of interests}

The authors declare no conflict of interest.

\section{List of abbreviations}

2-D bi-dimensional

3-D three-dimensional

3NCP N-benzyl-3-carboxylpyridinium chloride

BOD bilirubin oxidase

CAD computer aided design

CB carbon black 


$\begin{array}{ll}\text { CDF } & \text { computational fluid dynamics } \\ \text { CNT } & \text { carbon nanotube } \\ \text { CTAB } & \text { cetyltrimethylammonium bromide } \\ \text { DMAQ } & \text { dimethyl-2,6-dihydroxyanthraquinone } \\ \text { DPE } & \text { discrete particle electrolyser } \\ \text { ESS } & \text { energy storage system } \\ \text { FrTSCN } & \text { furfuraldehydethiosemicarbazone } \\ \text { GDE } & \text { gas diffusion electrode } \\ \text { HDPE } & \text { high density polyethylene } \\ \text { NASICON } & \text { sodium super ionic conductor } \\ \text { MEA } & \text { membrane electrode assembly } \\ \text { MEM } & \text { N-methyl-N-ethylmorpholinium bromide } \\ \text { RFB } & \text { redox flow battery } \\ \text { MEP } & \text { N-methyl-N-ethyl-pyrrolidinium bromide } \\ \text { MSA } & \text { methanesulfonic acid } \\ \text { MWCNT } & \text { multi-walled carbon nanotube } \\ \text { PAF } & \text { polyamine } \\ \text { Pani } & \text { polyaniline } \\ \text { PGE } & \text { polymer gel electrolyte } \\ \text { PVA } & \text { pores per inch } \\ \text { Platinised titanium }\end{array}$


RTIL room temperature ionic liquid

RVC reticulated vitreous carbon

SEM scanning electron microscopy

SCE saturated calomel electrode

SHE standard hydrogen electrode

SOC state of charge

SWCNT single-walled carbon nanotube

TBAB tetrabutylammonium bromide

TEMPO 2,2,6,6-tetramethylpiperidinyl-N-oxyl

UPS uninterruptable power supply

XRD $\quad$-ray diffraction 


\section{References}

1. Alotto, P., M. Guarnieri, and F. Moro, Redox flow batteries for the storage of renewable energy: A review. Renew. Sustainable Energy Rev., 2014; 29: 325-35.

2. Gu, S., B. Xu, and Y. Yan, Electrochemical energy engineering: A new frontier of chemical engineering innovation. Annu. Rev. Chem. Biomol. Eng., 2014; 5: 429-54.

3. Barros, J.J.C., M.L. Coira, M.P.d.l.C. Lopez, and A.d.C. Gochi, Assessing the global sustainability of different electricity generation systems. Energy, 2015; 89: 473-89.

4. European Commission, Directorate-General for Energy., Energy 2020 - A strategy for competitive, sustainable and secure energy. Luxembourg: Publications Office of the European Union. 2011.

5. European Commission, Directorate-General for Energy, Proposal for a directive of the european parliament and of the council on the promotion of the use of energy from renewable sources. Brussels. 2016.

6. National Energy Adminstration (NEA), The 13th five-year plan for economic and social development of The People's Republic of China 2016-2020. Beijing, China. Compilation and Translation Bureau, Central Committee of the Communist Party of China. 2016.

7. Aneke, M. and M. Wang, Energy storage technologies and real life applications - A state of the art review. Appl. Energy, 2016; 179: 350-77.

8. Soloveichik, G.L., Battery technologies for large-scale stationary energy storage. Annu. Rev. Chem. Biomol. Eng., 2011; 2: 503-27.

9. Koohi-Kamali, S., V.V. Tyagi, N.A. Rahim, N.L. Panwar, and H. Mokhlis, Emergence of energy storage technologies as the solution for reliable operation of smart power systems: A review. Renew. Sustainable Energy Rev., 2013; 25: 135-65.

10. Yang, Z., J. Zhang, M.C.W. Kintner-Meyer, X. Lu, D. Choi, J.P. Lemmon, and J. Liu, Electrochemical energy storage for green grid. Chem. Rev., 2011; 111: 3577-613.

11. Srivastava, A.K., R. Zamora, and D. Bowman. Impact of distributed generation with storage on electric grid stability. In: Power and Energy Society General Meeting. 2011.

12. Ferreira, H.L., R. Garde, G. Fulli, W. Kling, and J.P. Lopes, Characterisation of electrical energy storage technologies. Energy, 2013; 53: 288-98.

13. Leadbetter, J. and L. Swan, Battery storage system for residential electricity peak demand shaving. Energy Build., 2012; 55: 685-92.

14. Divya, K.C. and J. Østergaard, Battery energy storage technology for power systems-An overview. Electr. Power Syst. Res., 2009; 79: 511-20.

15. Purvin, A., I. T.Papaioannou, and L. Debarberis, Application of battery-based storage systems in household-demand smoothening in electricity-distribution grids. Energy Convers. Manage., 2013; 65: 272-84. 
16. Bolund, B., H. Bernhoff, and M. Leijon, Flywheel energy and power storage systems. Renew. Sustainable Energy Rev., 2007; 11: 235-8.

17. Poullikkas, A., A comparative overview of large-scale battery systems for electricity storage. Renew. Sustainable Energy Rev., 2013; 27: 778-88.

18. Dell, R.M. and D.A.J. Rand, Energy storage — a key technology for global energy sustainability. J. Power Sources, 2001; 100: 2-17.

19. Perry, M.L. and A.Z. Weber, Advanced redox-flow batteries: A perspective. J. Electrochem. Soc., 2016; 163: A5064-7.

20. Taylor, P., R. Bolton, D. Stone, X.-P. Zhang, C. Martin, and P. Upham, Pathways for energy storage in the UK. Centre for Low Carbon Futures. 2012.

21. Arenas, L.F., C. Ponce de León, and F.C. Walsh, Engineering aspects of the design, construction and performance of modular redox flow batteries for energy storage. J. Energy Storage, 2017; 11: 119-53.

22. Bard, A.J., R. Parsons, and J. Jordan, Standard Potentials in Aqueous Solution. Taylor \& Francis. 1985.

23. Arenas, L.F., C. Ponce de León, and F.C. Walsh, Electrochemical redox processes involving soluble cerium species. Electrochim. Acta, 2016; 205: 226-47.

24. Jorné, J., J.T. Kim, and D. Kralik, The zinc-chlorine battery: half-cell overpotential measurements. J. Appl. Electrochem., 1979; 9: 573-9.

25. Lex, P. and B. Jonshagen, The zinc/bromine battery system for utility and remote area applications. Power Eng. J., 1999; 13: 142-8.

26. Tang, C. and D. Zhou, Methanesulfonic acid solution as supporting electrolyte for zincvanadium redox battery. Electrochim. Acta, 2012; 65: 179-84.

27. Cheng, J., L. Zhang, Y.-S. Yang, Y.-H. Wen, G.-P. Cao, and X.-D. Wang, Preliminary study of single flow zinc-nickel battery. Electrochem. Commun., 2007; 9: 2639-42.

28. Noack, J., N. Roznyatovskaya, T. Herr, and P. Fischer, The chemistry of redox-flow batteries. Angew. Chem. Int. Ed., 2015; 54: 9776-809.

29. Magnani, N.J., R. P.Clark, J.W. Braithwaite, D.M. Bush, P.C. Butler, J.M. Freese, K.R. Grothaus, K.D. Murphy, and P.E. Shoemaker, Exploratory battery technology development and testing report for 1985. Albuquerque, NM (USA). Sandia National Laboratories. 1987.

30. Selverston, S., R.F. Savinell, and J.S. Wainright, Zinc-iron flow batteries with common electrolyte. J. Electrochem. Soc., 2017; 164: A1069-75.

31. Li, B., Z. Nie, M. Vijayakumar, G. Li, J. Liu, V. Sprenkle, and W. Wang, Ambipolar zincpolyiodide electrolyte for a high-energy density aqueous redox flow battery. Nat. Commun., 2015; 6: 1-8. 
32. Leung, P., J. Palma, E. Garcia-Quismondo, L. Sanz, M.R. Mohamed, and M. Anderson, Evaluation of electrode materials for all-copper hybrid flow batteries. J. Power Sources, 2016; 310: 1-11.

33. Liu, C.C., R.T. Galasco, and R.F. Savinell, Operating performance of an Fe-Ti stationary redox battery in the presence of lead. J. Electrochem. Soc., 1982; 129: 2502-5.

34. Thaller, L.H. Electrically rechargeable REDOX flow cell. US Patent 3,996,064. 1976.

35. Hruska, L.W. and R.F. Savinell, Investigation of factors affecting performance of the ironredox battery. J. Electrochem. Soc., 1981; 128: 18-25.

36. Skyllas-Kazacos, M., M.H. Chakrabarti, S.A. Hajimolana, F.S. Mjalli, and M. Saleem, Progress in flow battery research and development. J. Electrochem. Soc., 2011; 158: R55-79.

37. Lin, K., Q. Chen, M.R. Gerhardt, L. Tong, S.B. Kim, L. Eisenach, A.W. Valle, D. Hardee, R.G. Gordon, M.J. Aziz, and M.P. Marshak, Alkaline quinone flow battery. Science, 2015; 349: $1529-32$.

38. Morrissey, P., Regenesys: a new energy storage technology. Int. J. Ambient Energy, 2000; 21: $213-20$.

39. Wills, R.G.A., J. Collins, D. Stratton-Campbell, C.T.J. Low, D. Pletcher, and F.C. Walsh, Developments in the soluble lead-acid flow battery. J. Appl. Electrochem., 2010; 40: 955-965.

40. Fang, B., S. Iwasa, Y. Wei, T. Arai, and M. Kumagai, A study of the $\mathrm{Ce}(\mathrm{III}) / \mathrm{Ce}(\mathrm{IV})$ redox couple for redox flow battery application. Electrochim. Acta, 2002; 47: 3971-76.

41. Leung, P.K., C. Ponce-de-León, C.T.J. Low, A.A. Shah, and F.C. Walsh, Characterization of a zinc-cerium flow battery. J. Power Sources, 2011; 196: 5174-85.

42. Linden, D. and T.B. Reddy, Handbook of batteries. McGraw-Hill. 2002.

43. Leung, P.K., X. Li, C. Ponce de León, L. Berlouis, C.T.J. Low, and F.C. Walsh, Progress in redox flow batteries, remaining challenges and their applications in energy storage. RSC Adv., 2012; 2: 10125-56.

44. Ponce de León, C. and F.C. Walsh, Zinc-bromine redox flow batteries, in Encyclopedia of Electrochemical Power Sources, C. Dyer J. Garche, P. Moseley, Z. Ogumi, D. Rand, B. Scrosati, Editor; 2009. p. 487-96.

45. Vincent, C.A. and B. Scrosati, Modern batteries: An Introduction to Electrochemical Power Sources. 2nd ed. Oxford; Burlington, MA: Butterworth Heinemann. 1997.

46. Bradley, C.S. Secondary battery. US Patent 312,802. 1885.

47. Edison, T.A. Reversible galvanic battery. US Patent 678,722. 1901.

48. Vertes, M.A., E.G. Katsoulis, J.E. Oxley, and K. Alfredson, Zinc/air high energy density rechargeable energy storage system. Great Neck, N.Y., USA. Leesona Corp. 1966.

49. Backhurst, J.R., E. Goodridge, R.E. Plimley, and M. Fleischmann, Some aspects of a fluidized zinc/oxygen electrode system. Nature, 1969; 221: 55-7. 
50. Electric Power Research Institute, Development of the zinc-chloride battery for utility applications. Electric Power Research Institute. 1987.

51. Appleby, A., J. Jacquelin, and J. Pompon, Charge-discharge behavior of the C.G.E. circulating zinc-air vehicle battery. International Automotive Engineering Congress and Exposition. Society of Automotive Engineers Inc.; 1977.

52. Butler, P.C., P.A. Eidler, P.G. Grimes, S.E. Klassen, and R.C. Miles, Zinc/ Bromine Batteries, in Handbook of Batteries, D. Linden and T.B. Reddy. McGraw-Hill; 2002.

53. Swan, D.H., B. Dickinson, M. Arikara, and G.S. Tomazic. Demonstration of a zinc bromine battery in an electric vehicle. In: Battery Conference on Applications and Advances, 1994., Proceedings of the Ninth Annual. 1994. p. 104-109.

54. Goldstein, J., I. Brown, and B. Koretz, New developments in the Electric Fuel Ltd. zinc/air system. J. Power Sources, 1999; 80: 171-9.

55. Clarke, R., B. Dougherty, S. Harrison, P. Millington, and S. Mohanta. Cerium batteries. US Patent application 2004/0202925 A1. 2004.

56. Neburchilov, V., H. Wang, J.J. Martin, and W. Qu, A review on air cathodes for zinc-air fuel cells. J. Power Sources, 2010; 195: 1271-91.

57. Banerjee, S., Y. Ito, M. Klein, M.E. Nyce, D. Steingart, R. Plivelich, and J. Gallaway. Nickelzinc flow battery. US Patent application 2013/0113431 A1, 2013.

58. Wu, S., Y. Zhao, D. Li, Y. Xia, and S. Si, An asymmetric Zn/Ag doped polyaniline microparticle suspension flow battery with high discharge capacity. J. Power Sources, 2015; 275: 305-11.

59. Arenas, L.F., C. Ponce de León, and F.C. Walsh, Mass transport and active area of porous $\mathrm{Pt} / \mathrm{Ti}$ electrodes for the $\mathrm{Zn}-\mathrm{Ce}$ redox flow battery determined from limiting current measurements. Electrochim. Acta, 2016; 221: 154-66.

60. Leung, P.K., C. Ponce de León, and F.C. Walsh, An undivided zinc-cerium redox flow battery operating at room temperature (295 K). Electrochem. Commun., 2011; 13: 770-3.

61. Pan, J., L. Ji, Y. Sun, P. Wan, J. Cheng, Y. Yang, and M. Fan, Preliminary study of alkaline single flowing Zn-O2 battery. Electrochem. Commun., 2009; 11: 2191-4.

62. Attia, A. and R.A. Putt, Gould Inc, United States. Department of Energy. Division of Energy Storage. Electric Power Research Institute. Development of Zinc Bromide Batteries for Stationary Energy Storage. United States. 1982.

63. Bellows, R.E., H.; Grimes, P.; Kantner, E.; Malachesky, P.; Newby K.; Tsien, H., Development of a circulating zinc-bromine battery Phase I. final report. Exxon Research and Engineering Company, Linden, NJ. Advanced Energy Systems Labs.; Department of Energy, Washington, DC. 1983. 
64. Leo, A. Status of zinc-bromine battery development at Energy Research Corporation. In: Energy Conversion Engineering Conference, 1989. IECEC-89., Proceedings of the 24th Intersociety. 1989. p. 1303-1309 vol.3.

65. Bolstad, J.J. and R.C. Miles. Development of the zinc/bromine battery at Johnson Controls Inc. In: Energy Conversion Engineering Conference, 1989. IECEC-89., Proceedings of the 24th Intersociety. 1989. p. 1311-1318.

66. Futamata, M., S. Higuchi, O. Nakamura, I. Ogino, Y. Takada, S. Okazaki, S. Ashimura, and S. Takahashi, Performance testing of $10 \mathrm{~kW}$-class advanced batteries for electric energy storage systems in Japan. J. Power Sources, 1988; 24: 137-55.

67. Clark, N.H. and P. Eidler, Development of zinc/bromine batteries for load leveling applications: Phase 2. final report. Sandia National Laboratories (SNL), Albuquerque, NM, and Livermore, CA (United States).; Department of Energy, Washington, DC.; 1999.

68. Eustace, D.J., Bromine complexation in zinc-bromine circulating batteries. J. Electrochem. Soc., 1980; 127: 528-32.

69. Sun, X., T. Souier, M. Chiesa, and A. Vassallo, Effect of surface transport properties on the performance of carbon plastic electrodes for flow battery applications. Electrochim. Acta, 2014; 148: 104-10.

70. Cathro, K.J., K. Cedzynska, D.C. Constable, and P.M. Hoobin, Selection of quaternary ammonium bromides for use in zinc/bromine cells. J. Power Sources, 1986; 18: 349-70.

71. Mastragostino, M. and S. Valcher, Polymeric salt as bromine complexing agent in a $\mathrm{Zn}-\mathrm{Br}_{2}$ model battery. Electrochim. Acta, 1983; 28: 501-5.

72. Bryans, D., L. Berlouis, M. Spicer, B.G. McMillan, and A. Wark, Synthesis and characterisation of novel additives for use in the hybrid ZnBr2 flow battery. ECS Trans., 2017; 77: 33-6.

73. Lee, H.J., D.-W. Kim, and J.H. Yang, Estimation of state-of-charge for zinc-bromine flow batteries by in situ raman spectroscopy. J. Electrochem. Soc., 2017; 154: A754-9.

74. Carr, P., P.C. Symons, and D.J. Aller. Operational zinc chlorine battery based on a water store. US Patent 4,146,680. 1979.

75. Aymé-Perrot, D., S. Walter, Z. Gabelica, and S. Valange, Evaluation of carbon cryogels used as cathodes for non-flowing zinc-bromine storage cells. J. Power Sources, 2008; 175: 64450.

76. Cedzynska, K., Properties of modified electrolyte for zinc-bromine cells. Electrochim. Acta, 1995; 40: 971-6.

77. Vogel, I. and A. Möbius, On some problems of the zinc - bromine system as an electric energy storage system of higher efficiency-I. Kinetics of the bromine electrode. Electrochim. Acta, 1991; 36: 1403-8. 
78. Yang, J.H., H.S. Yang, H.W. Ra, J. Shim, and J.-D. Jeon, Effect of a surface active agent on performance of zinc/bromine redox flow batteries: Improvement in current efficiency and system stability. J. Power Sources, 2015; 275: 294-7.

79. Lancry, E., B.-Z. Magnes, I. Ben-David, and M. Freiberg, New bromine complexing agents for bromide based batteries. ECS Trans., 2013; 53: 107-15.

80. Easton, M.E., P. Turner, A.F. Masters, and T. Maschmeyer, Zinc bromide in aqueous solutions of ionic liquid bromide salts: the interplay between complexation and electrochemistry. RSC Adv., 2015; 5: 83674-81.

81. Rajarathnam, G.P., M.E. Easton, M. Schneider, A.F. Masters, T. Maschmeyer, and A.M. Vassallo, The influence of ionic liquid additives on zinc half-cell electrochemical performance in zinc/bromine flow batteries. RSC Adv., 2016; 6: 27788-97.

82. Popov, A.I. and D.H. Geske, Studies on the chemistry of halogen and of polyhalides. XVI. Voltammetry of bromine and interhalogen species in acetonitrile. J. Am. Chem. Soc., 1958; 80: 5346-9.

83. Singh, P., K. White, and A.J. Parker, Application of non-aqueous solvents to batteries part I. Physicochemical properties of propionitrile/water two-phase solvent relevant to zincbromine. J. Power Sources, 1983; 10: 309-18.

84. Singh, P., Application of non-aqueous solvents to batteries. J. Power Sources, 1984; 11: 135 42.

85. Bennett, B.E. The bromine/nitrobenzene redox flow battery: mechanism of the bromide/bromine reaction in nitrobenzene and characterization of supporting electrolytes. Materials Science and Engineering: The University of Texas at Austin. Texas. 2015.

86. Rajarathnam, G.P., M. Schneider, X. Sun, and A.M. Vassallo, The influence of supporting electrolytes on zinc half-cell performance in zinc/bromine flow batteries. J. Electrochem. Soc., 2016; 163: A5112-7.

87. Wu, M.C., T.S. Zhao, H.R. Jiang, Y.K. Zeng, and Y.X. Ren, High-performance zinc bromine flow battery via improved design of electrolyte and electrode. J. Power Sources, 2017; 355: $62-8$.

88. Suresh, S., T. Kesavan, Y. Munaiah, I. Arulraj, S. Dheenadayalan, and P. Ragupathy, Zincbromine hybrid flow battery: effect of zinc utilization and performance characteristics. RSC Adv., 2014; 4: 37947-53.

89. Cathro, K.J., D.C. Constable, and P.M. Hoobin, Performance of porous plastic separators in zinc/bromine cells. J. Power Sources, 1988; 22: 29-57.

90. Rose, D.M. and S.R. Ferreira, Performance testing of zinc-bromine flow batteries for remote telecom sites. United States of America. Sandia National Laboratories, Albuquerque, NM. 2013. 
91. Will, F.G., Bromine diffusion through Nafion ${ }^{\circledR}$ perfluorinated ion exchange membranes. J. Electrochem. Soc., 1979; 126: 36-43.

92. Li, M., H. Su, Q. Qiu, G. Zhao, Y. Sun, and W. Song, A quaternized polysulfone membrane for zinc-bromine redox flow battery. J. Chem., 2014; 15: 1-5.

93. Zhang, L., H. Zhang, Q. Lai, X. Li, and Y. Cheng, Development of carbon coated membrane for zinc/bromine flow battery with high power density. J. Power Sources, 2013; 227: 41-7.

94. Rajarathnam, G.P. and A.M. Vassallo, The Zinc/Bromine Flow Battery: Materials Challenges and Practical Solutions for Technology Advancement. 1st ed. Singapore: Springer Singapore. 2016.

95. Nagai, Y., R. Komiyama, H. Miyashita, and S.-S. Lee. Miniaturization of $\mathrm{Zn} / \mathrm{Br}$ redox flow battery cell. In: IEEE 11th Annual International Conference on Nano/Micro Engineered and Molecular Systems (NEMS). 2016.

96. Wang, C., Q. Lai, P. Xu, D. Zheng, X. Li, and H. Zhang, Cage-like porous carbon with superhigh activity and $\mathrm{Br} 2$-complex-entrapping capability for bromine-based flow batteries. Adv. Mater., 2017; 29: 1605815.

97. Cathro, K.J., K. Cedzynska, and D.C. Constable, Preparation and performance of plasticbonded-carbon bromine electrodes. J. Power Sources, 1987; 19: 337-56.

98. Jang, W.I., J.W. Lee, Y.M. Baek, and O.O. Park, Development of a PP/carbon/CNT composite electrode for the zinc/bromine redox flow battery. Macromol. Res., 2016; 24: 276-81.

99. Yang, H.S., J.H. Park, H.W. Ra, C.-S. Jin, and J.H. Yang, Critical rate of electrolyte circulation for preventing zinc dendrite formation in a zinc-bromine redox flow battery. J. Power Sources, 2016; 325: 446-52.

100. Kalu, E.E. and R.E. White, $\mathrm{Zn} / \mathrm{Br} 2$ cell: Effects of plated zinc and complexing organic phase. AIChE Journal, 1991; 37: 1164-74.

101. Guillaume, P., N. Leclerc, C. Boulanger, J.M. Lecuire, and F. Lapicque, Investigation of optimal conditions for zinc electrowinning from aqueous sulfuric acid electrolytes. J. Appl. Electrochem., 2007; 37: 1237-43.

102. Pan, J., Y. Wen, J. Cheng, J. Pan, Z. Bai, and Y. Yang, Zinc deposition and dissolution in sulfuric acid onto a graphite-resin composite electrode as the negative electrode reactions in acidic zinc-based redox flow batteries. J. Appl. Electrochem., 2013; 43: 541-51.

103. Mackinnon, D.J., R.M. Morrison, J.E. Mouland, and P.E. Warren, The effects of antimony and glue on zinc electrowinning from Kidd Creek electrolyte. J. Appl. Electrochem., 1990; 20: 728-36.

104. Iacovangelo, C.D. and F.G. Will, Parametric study of zinc deposition on porous carbon in a flowing electrolyte cell. J. Electrochem. Soc., 1985; 132: 851-57. 
105. Wang, C., X. Li, X. Xi, P. Xu, Q. Lai, and H. Zhang, Relationship between activity and structure of carbon materials for $\mathrm{Br} 2 / \mathrm{Br}$ - in zinc bromine flow batteries. RSC Adv., 2016; 6: 40169-74.

106. Munaiah, Y., S. Dheenadayalan, P. Ragupathy, and V.K. Pillai, High performance carbon nanotube based electrodes for zinc bromine redox flow batteries. J. Solid State Sci. Technol., 2013; 2: M3182-6.

107. Munaiah, Y., S. Suresh, S. Dheenadayalan, V.K. Pillai, and P. Ragupathy, Comparative electrocatalytic performance of single-walled and multiwalled carbon nanotubes for zinc bromine redox flow batteries. J. Phys. Chem. C, 2014; 118: 14795-804.

108. Munaiaha, Y., P. Ragupathy, and V.K. Pillai, Single-step synthesis of halogenated graphene through electrochemical exfoliation and its utilization as electrodes for zinc bromine redox flow battery. J. Electrochem. Soc., 2016; 163: A2899-910.

109. Lai, Q., H. Zhang, X. Li, L. Zhang, and Y. Cheng, A novel single flow zinc-bromine battery with improved energy density. J. Power Sources, 2013; 235: 1-4.

110. Allen, C.J., S. Abraham, and K.L. Hardee. Electrode for electrochemical cells and composition thereof. WO2016097217. 2016.

111. Cho, K.T., P. Albertus, V. Battaglia, A. Kojic, V. Srinivasan, and A.Z. Weber, Optimization and analysis of high-power hydrogen/bromine-flow batteries for grid-scale energy storage. Energy Technol., 2013; 1: 596-608.

112. Bender, D., R. Byrne, and D. Borneo, ARRA energy storage demonstration projects: lessons learned and recommendations. United States of America. Sandia National Laboratories (SNLNM), Albuquerque, NM (United States), U.S. Department of Energy, Oak Ridge, TN. 2015.

113. Rose, D.M., B.L. Schenkman, and D.R. Borneo, Test report : Raytheon / KTech RK30 energy storage system. United States of America. Sandia National Laboratories (SNL-NM), Albuquerque, NM (United States). 2013.

114. Redflow Limited. Redflow Sustainable Energy Storage. www.redflow.com; 2017 [accessed 29.08.17].

115. Donghyeon, K. and J. Joonhyeon, Study on durability and stability of an aqueous electrolyte solution for zinc bromide Hybrid flow batteries. J. Phys.: Conf. Ser, 2015; 574: 1-4.

116. Evans, T.I. and R.E. White, A review of mathematical modeling of the zinc/bromine flow cell and battery. J. Electrochem. Soc., 1987; 134: 2725-33.

117. Yang, S.-C., An approximate model for estimating the faradaic efficiency loss in zinc/bromine batteries caused by cell self-discharge. J. Power Sources, 1994; 50: 343-60.

118. Lee, J. and J.R. Selman, Effects of separator and terminal on the current distribution in parallel-plate electrochemical flow reactors. J. Electrochem. Soc., 1982; 129: 1670-8.

119. Jia, Y., S. Cheng, D. Chu, and X. Li. Numerical simulation of bromine crossover behavior in flow battery. In: Advances in Materials, Machinery, Electronics I. 2017. 
120. Spotnitz, R.M., R.P. Kreh, J.T. Lundquist, and P.J. Press, Mediated electrosynthesis with cerium (IV) in methanesulphonic acid. J. Appl. Electrochem., 1990; 20: 209-15.

121. Harrison, S. and A. Theoret, The electrosynthesis of naphthoquinone, and tetrahydroanthraquinone. J. New Mat. Electrochem. Syst., 1999; 2: 1-9.

122. Walsh, F.C., C. Ponce de Léon, L. Berlouis, G. Nikiforidis, L.F. Arenas-Martínez, D. Hodgson, and D. Hall, The development of $\mathrm{Zn}-\mathrm{Ce}$ hybrid redox flow batteries for energy storage and their continuing challenges. ChemPlusChem, 2015; 80: 288-311.

123. Xie, Z., Q. Liu, Z. Chang, and X. Zhang, The developments and challenges of cerium halfcell in zinc-cerium redox flow battery for energy storage. Electrochim. Acta, 2013; 90: 695704.

124. Nikiforidis, G. and W.A. Daoud, Indium modified graphite electrodes on highly zinc containing methanesulfonate electrolyte for zinc-cerium redox flow battery. Electrochim. Acta, 2015; 168: 394-402.

125. Nikiforidis, G., L. Berlouis, D. Hall, and D. Hodgson, A study of different carbon composite materials for the negative half-cell reaction of the zinc cerium hybrid redox flow cell. Electrochim. Acta, 2013; 113: 412-23.

126. Nikiforidis, G., L. Berlouis, D. Hall, and D. Hodgson, Evaluation of carbon composite materials for the negative electrode in the zinc-cerium redox flow cell. J. Power Sources, 2012; 206: 497-503.

127. Leung, P.K., C. Ponce-de-León, C.T.J. Low, and F.C. Walsh, Zinc deposition and dissolution in methanesulfonic acid onto a carbon composite electrode as the negative electrode reactions in a hybrid redox flow battery. Electrochim. Acta, 2011; 56: 6536-46.

128. Arenas, L.F., C.P.d. León, and F.C. Walsh., Study of hydrogen evolution inhibitors for zinc electrodeposition. Unpublished results.

129. Van Parys, H., G. Telias, V. Nedashkivskyi, B. Mollay, I. Vandendael, S. Van Damme, J. Deconinck, and A. Hublin, On the modeling of electrochemical systems with simultaneous gas evolution. Case study: The zinc deposition mechanism. Electrochim. Acta, 2010; 55: 5709-18.

130. Nikiforidis, G., R. Cartwright, D. Hodgson, D. Hall, and L. Berlouis, Factors affecting the performance of the Zn-Ce redox flow battery. Electrochim. Acta, 2014; 140: 139-44.

131. Zhang, Q.B., Y.X. Hua, T.G. Dong, and D.G. Zhou, Effects of temperature and current density on zinc electrodeposition from acidic sulfate electrolyte with [BMIM]HSO4 as additive. J. Appl. Electrochem., 2009; 39: 1207-16.

132. Zhang, Q. and Y. Hua, Effects of 1-butyl-3-methylimidazolium hydrogen sulfate[BMIM]HSO4 on zinc electrodeposition from acidic sulfate electrolyte. J. Appl. Electrochem., 2008; 39: 261-7. 
133. Piron, D.L., D. Mathieu, and M. D'Amboise, Zinc electrowinning with 2-butyne-1,4-diol. Can. J. Chem. Eng., 1987; 65: 685-8.

134. Fenelon, A.M. and C.B. Breslin, An electrochemical study of the formation of benzotriazole surface films on copper, zinc and a copper-zinc alloy. J. Appl. Electrochem., 2001; 31: 50916.

135. Tripathy, B.C., S.C. Das, P. Singh, and G.T. Hefter, Zinc electrowinning from acidic sulphate solutions. Part III: Effects of quaternary ammonium bromides. J. Appl. Electrochem., 1999; 29: 1229-35.

136. Oliveira, E.M. and I.A. Carlos, Voltammetric and morphological characterization of zinc electrodeposition from acid electrolytes containing boric-polyalcohol complexes. J. Appl. Electrochem., 2008; 38: 1203-10.

137. Sato, R., Crystal growth of electrodeposited zinc: An electron diffraction and electron microscopic study. J. Electrochem. Soc., 1959; 106: 206-11.

138. Yano, M., S. Fujitani, K. Nishio, Y. Akai, and M. Kurimura, Effect of additives in zinc alloy powder on suppressing hydrogen evolution. J. Power Sources, 1998; 74: 129-34.

139. Ichino, R., C. Cachet, and R. Wiart, Mechanism of zinc electrodeposition in acidic sulfate electrolytes containing Pb2+ ions. Electrochim. Acta, 1996; 41: 1031-39.

140. Hosny, A.Y., Electrowinning of zinc from electrolytes containing anti-acid mist surfactant. Hydrometallurgy, 1993; 32: 261-9.

141. Cachet, C. and R. Wiart, Influence of a perfluorinated surfactant on the mechanism of zinc deposition in acidic electrolytes. Electrochim. Acta, 1999; 44: 4743-51.

142. Tripathy, B.C., S.C. Das, P. Singh, G.T. Hefter, and V.N. Misra, Zinc electrowinning from acidic sulphate solutions Part IV: Effects of perfluorocarboxylic acids. J. Electroanal Chem., 2004; 565: 49-56.

143. Troquet, M. and J. Pagetti, Inhibition of metallic corrosion in an acid medium by means of phosphonium salts: zinc and iron. Mater. Corros., 1983; 34: 557-62.

144. Tripathy, B.C., S.C. Das, G.T. Hefter, and P. Singh Zinc electrowinning from acidic sulfate solutions: Part I: Effects of sodium lauryl sulfate. J. Appl. Electrochem., 1997; 27: 673-8.

145. Mouanga, M., L. Ricq, J. Douglade, and P. Berçot, Effects of some additives on the corrosion behaviour and preferred orientations of zinc obtained by continuous current deposition. J. Appl. Electrochem., 2007; 37: 283-9.

146. Leung, P.K., C. Ponce de León, F.J. Recio, P. Herrasti, and F.C. Walsh, Corrosion of the zinc negative electrode of zinc-cerium hybrid redox flow batteries in methanesulfonic acid. J. Appl. Electrochem., 2014; 44: 1025-35.

147. Vijayabarathi, T., D. Velayutham, and M. Noel, Influence of aromatic reactants and products involved in the two stage electrochemical oxidation on the voltammetric behaviour of Ce(IV)/Ce(III) redox couple. J. Appl. Electrochem., 2001; 31: 979-86. 
148. Devadoss, V., M. Noel, K. Jayaraman, and C. Ahmed Basha, Electrochemical behaviour of $\mathrm{Mn3}+/ \mathrm{Mn} 2+, \mathrm{Co} 3+/ \mathrm{Co} 2+$ and $\mathrm{Ce} 4+/ \mathrm{Ce} 4+$ redox mediators in methanesulfonic acid. J. Appl. Electrochem., 2003; 33: 319-23.

149. Xie, Z., D. Zhou, F. Xiong, S. Zhang, and K. Huang, Cerium-zinc redox flow battery: positive half-cell electrolyte studies. J. Rare Earth, 2011; 29: 567-73.

150. Nikiforidis, G., L. Berlouis, D. Hall, and D. Hodgson, An electrochemical study on the positive electrode side of the zinc-cerium hybrid redox flow battery. Electrochim. Acta, 2014; 115: 621-9.

151. Xiong, F., D. Zhou, Z. Xie, and Y. Chen, A study of the $\mathrm{Ce}^{3+} / \mathrm{Ce}^{4+}$ redox couple in sulfamic acid for redox battery application. Appl. Energy, 2012; 99: 291-6.

152. Leung, P.K., C. Ponce de León, C.T.J. Low, and F.C. Walsh, $\mathrm{Ce}(\mathrm{III}) / \mathrm{Ce}(\mathrm{IV})$ in methanesulfonic acid as the positive half cell of a redox flow battery. Electrochim. Acta, 2011; 56: 2145-53.

153. Nikiforidis, G., L. Berlouis, D. Hall, and D. Hodgson, Charge/discharge cycles on Pt and PtIr based electrodes for the positive side of the zinc-cerium hybrid redox flow battery. Electrochim. Acta, 2014; 125: 176-82.

154. Xie, Z., F. Xiong, and D. Zhou, Study of the $\mathrm{Ce}^{3+} / \mathrm{Ce}^{4+}$ redox couple in mixed-acid media (CH3SO3H and H2SO4) for redox flow battery application. Energy Fuels, 2011; 25: 2399404.

155. Nikiforidis, G. and W.A. Daoud, Effect of mixed acid media on the positive side of the hybrid zinc-cerium redox flow battery. Electrochim. Acta, 2014; 141: 255-62.

156. Leung, P.K., C. Ponce de León, and F.C. Walsh, The influence of operational parameters on the performance of an undivided zinc-cerium flow battery. Electrochim. Acta, 2012; 80: 714.

157. Arenas, L.F., F.C. Walsh, and C. Ponce de León, The importance of cell geometry and electrolyte properties to the cell potential of Zn-Ce hybrid flow batteries. J. Electrochem. Soc., 2016; 163: A5170-9.

158. Arenas, L.F. An electrochemical engineering approach to improvements in the zinc-cerium redox flow battery. PhD thesis. Faculty of Engineering and the Environment University of Southampton. UK. 2017.

159. $\mathrm{Yu}, \mathrm{X}$. and A. Manthiram, A zinc-cerium cell for energy storage using a sodium-ion exchange membrane. Adv. Sustainable Syst., 2017.

160. Chakkaravarthy, C., A.K.A. Waheed, and H.V.K. Udupa, Zinc - air alkaline batteries - A review. J. Power Sources, 1981; 6: 203-28.

161. Li, Y. and H. Dai, Recent advances in zinc-air batteries. Chem. Soc. Rev., 2014; 43: 5257-75.

162. Pei, P., K. Wang, and Z. Ma, Technologies for extending zinc-air battery's cyclelife: A review. Appl. Energy, 2014; 128: 315-24. 
163. Rahman, M.A., X. Wang, and C. Wen, High energy density metal-air batteries: A review. J. Electrochem. Soc., 2013; 160: A1759-71.

164. Wang, J., Y. Li, and X. Sun, Challenges and opportunities of nanostructured materials for aprotic rechargeable lithium-air batteries. Nano Energy, 2013; 2: 443-67.

165. Fluidic Energy. Fluidic Energy. http://fluidicenergy.com/; 2016 [accessed 29.08.17].

166. US Department of Energy. Zinc-air grid energy storage. http://arpae.energy.gov/sites/default/files/documents/files/FluidicEnergy_GRIDS_ExternalImpactShee t FINAL.pdf; 2016 [accessed 29.08.17].

167. Bockris, J.O.M., Z. Nagy, and A. Damjanovic, On the deposition and dissolution of zinc in alkaline solutions. J. Electrochem. Soc., 1972; 119: 285-95.

168. Schlesinger, M. and M. Paunovic, Electrodeposition of Zinc and Zinc Alloys, in Modern Electroplating, René Winand, Editor., John Wiley \& Sons, Inc.: Hoboken, NJ, USA.; 2010. p. 285-307.

169. Ortiz-Aparicio, J.L., Y. Meas, G. Trejo, R. Ortega, T.W. Chapman, and E. Chainet, Effects of organic additives on zinc electrodeposition from alkaline electrolytes. J. Appl. Electrochem., 2012; 43: 289-300.

170. Wen, Y.-H., J. Cheng, L. Zhang, X. Yan, and Y.-S. Yang, The inhibition of the spongy electrocrystallization of zinc from doped flowing alkaline zincate solutions. J. Power Sources, 2009; 193: 890-4.

171. Wen, Y., T. Wang, J. Cheng, J. Pan, G. Cao, and Y. Yang, Lead ion and tetrabutylammonium bromide as inhibitors of the growth of spongy zinc in single flow zinc/nickel batteries. Electrochim. Acta, 2012; 59: 64-8.

172. Kavitha, B., P. Santhosh, M. Renukadevi, A. Kalpana, P. Shakkthivel, and T. Vasudevan, Role of organic additives on zinc plating. Surf. Coat. Technol., 2006; 201: 3438-42.

173. Yang, H., Y. Cao, X. Ai, and L. Xiao, Improved discharge capacity and suppressed surface passivation of zinc anode in dilute alkaline solution using surfactant additives. J. Power Sources, 2004; 128: 97-101.

174. Lee, S.-M., Y.-J. Kim, S.-W. Eom, N.-S. Choi, K.-W. Kim, and S.-B. Cho, Improvement in self-discharge of $\mathrm{Zn}$ anode by applying surface modification for $\mathrm{Zn}$-air batteries with high energy density. J. Power Sources, 2013; 227: 177-84.

175. Müller, S., F. Holzer, and O. Haas, Optimized zinc electrode for the rechargeable zinc-air battery. J. Appl. Electrochem., 1998; 28: 895-8.

176. Lee, C.W., K. Sathiyanarayanan, S.W. Eom, H.S. Kim, and M.S. Yun, Effect of additives on the electrochemical behaviour of zinc anodes for zinc/air fuel cells. J. Power Sources, 2006; 160: 161-4.

177. Naybour, R.D., The effect of electrolyte flow on the morphology of zinc electrodeposited from aqueous alkaline solution containing zincate ions. J. Electrochem. Soc., 1969; 116: 520-4. 
178. Ito, Y., M. Nyce, R. Plivelich, M. Klein, D. Steingart, and S. Banerjee, Zinc morphology in zinc-nickel flow assisted batteries and impact on performance. J. Power Sources, 2011; 196: 2340-5.

179. Jiratchayamaethasakul, C., N. Srijaroenpramong, T. Bunyangyuen, W. Arpavate, N. Wongyao, A. Therdthianwong, and S. Therthianwong, Effects of anode orientation and flow channel design on performance of refuelable zinc-air fuel cells. J. Appl. Electrochem., 2014; 44: 1205-18.

180. Smedley, S.I. and X.G. Zhang, A regenerative zinc-air fuel cell. J. Power Sources, 2007; 165: 897-904.

181. Parker, J.F., C.N. Chervin, E.S. Nelson, D.R. Rolison, and J.W. Long, Wiring zinc in three dimensions re-writes battery performance-dendrite-free cycling. Energy Environ. Sci., 2014; 7: 1117-24.

182. Yan, Z., E. Wang, L. Jiang, and G. Sun, Superior cycling stability and high rate capability of three-dimensional $\mathrm{Zn} / \mathrm{Cu}$ foam electrodes for zinc-based alkaline batteries. RSC Adv., 2015; 5: 83781-7.

183. Shaigan, N., W. Qu, and T. Takeda, Morphology control of electrodeposited zinc from alkaline zincate solutions for rechargeable zinc air batteries. ECS Trans., 2010; 28: 35-44.

184. Wang, K., P. Pei, Z. Ma, H. Xu, P. Li, and X. Wang, Morphology control of zinc regeneration for zinc-air fuel cell and battery. J. Power Sources, 2014; 271: 65-75.

185. Wang, K., P. Pei, Z. Ma, H. Chen, H. Xu, D. Chen, and X. Wang, Dendrite growth in the recharging process of zinc-air batteries. J. Mater. Chem. A, 2015; 3: 22648-55.

186. Wang, Z.-L., D. Xu, J.-J. Xu, and X.-B. Zhang, Oxygen electrocatalysts in metal-air batteries: from aqueous to nonaqueous electrolytes. Chem. Soc. Rev., 2014; 43: 7746-86.

187. Kinoshita, K., Electrochemical Oxygen Technology. John Wiley \& Sons. 1992.

188. Vielstich, W., A. Lamm, and H.A. Gasteiger, Handbook of Fuel Cells. Wiley. 2003.

189. L'Her, M., Redox Properties, Electrochemistry of Oxygen, in Encyclopedia of Electrochemistry. Wiley-VCH Verlag GmbH \& Co. KGaA; 2007.

190. Pletcher, D. and X. Li, Prospects for alkaline zero gap water electrolysers for hydrogen production. Int. J. Hydrogen Energy, 2011; 36: 15089-104.

191. Cao, R., J.-S. Lee, M. Liu, and J. Cho, Recent progress in non-precious catalysts for metal-air batteries. Adv. Energy Mater., 2012; 2: 816-29.

192. Cheng, F. and J. Chen, Metal-air batteries: from oxygen reduction electrochemistry to cathode catalysts. Chem. Soc. Rev., 2012; 41: 2172-92.

193. Trotochaud, L. and S.W. Boettcher, Precise oxygen evolution catalysts: Status and opportunities. Scripta Mater., 2014; 74: 25-32.

194. Kraytsberg, A. and Y. Ein-Eli, The impact of nano-scaled materials on advanced metal-air battery systems. Nano Energy, 2013; 2: 468-80. 
195. Chen, G., S.R. Bare, and T.E. Mallouk, Development of supported bifunctional electrocatalysts for unitized regenerative fuel cells. J. Electrochem. Soc., 2002; 149: A10929.

196. Ioroi, T., Z. Siroma, N. Fujiwara, S.-i. Yamazaki, and K. Yasuda, Sub-stoichiometric titanium oxide-supported platinum electrocatalyst for polymer electrolyte fuel cells. Electrochem. Commun., 2005; 7 : 183-8.

197. Wang, Y.-J., D.P. Wilkinson, and J. Zhang, Noncarbon support materials for polymer electrolyte membrane fuel cell electrocatalysts. Chem. Rev., 2011; 111: 7625-51.

198. Lee, D.U., J.-Y. Choi, K. Feng, H.W. Park, and Z. Chen, Advanced extremely durable 3D bifunctional air electrodes for rechargeable zinc-air batteries. Adv. Energy Mater., 2014; 4: 13101389-494.

199. Li, P.-C., C.-C. Hu, T.-H. You, and P.-Y. Chen, Development and characterization of bifunctional air electrodes for rechargeable zinc-air batteries: Effects of carbons. Carbon, 2017; 111: 813-21.

200. Sumboja, A., X. Ge, G. Zheng, F.W.T. Goh, T.S.A. Hor, Y. Zong, and Z. Liu, Durable rechargeable zinc-air batteries with neutral electrolyte and manganese oxide catalyst. J. Power Sources, 2016; 332: 330-6.

201. Mainar, A.R., L.C. Colmenares, O. Leonet, F. Alcaide, J.J. Iruin, S. Weinberger, V. Hacker, E. Iruin, I. Urdanpilleta, and J. A. Blazquez, Manganese oxide catalysts for secondary zinc air batteries: from electrocatalytic activity to bifunctional air electrode performance. Electrochim. Acta, 2016; 217: 80-91.

202. Zloczewska, A. and M. Jönsson-Niedziolka, Efficient air-breathing biocathodes for zinc/oxygen batteries. J. Power Sources, 2013; 228: 104-11.

203. Li, X., D. Pletcher, A.E. Russell, F.C. Walsh, R.G.A. Wills, S.F. Gorman, S.W.T Price, and S.J. Thompson, A novel bifunctional oxygen GDE for alkaline secondary batteries. Electrochem. Commun., 2013; 34: 228-30.

204. Price, S.W.T., S. Thompson, X. Li, S. Gorman, D. Pletcher, A. Russell, F.C. Walsh, and R.G.A Wills, The fabrication of a bifunctional oxygen GDE without carbon components for alkaline secondary batteries. J. Power Sources, 2014; 259: 43-49.

205. Pletcher, D., X. Li, S. Price, A. Russell, T. Sönmez, and S. Thompson, Comparison of the spinels $\mathrm{Co}_{3} \mathrm{O}_{4}$ and $\mathrm{NiCo}_{2} \mathrm{O}_{4}$ as bifunctional oxygen catalysts in alkaline media. Electrochim. Acta, 2016; 188: 286-93.

206. Wei, L., H.E. Karahan, S. Zhai, H. Liu, X. Chen, Z. Zhou, Y. Lei, Z. Liu, and Y. Chen, Amorphous bimetallic oxide-graphene hybrids as bifunctional oxygen electrocatalysts for rechargeable Zn-air batteries. Adv. Mater., 2017; Aug: 1701410.

207. Bidault, F., D.J.L. Brett, P.H. Middleton, and N.P. Brandon, Review of gas diffusion cathodes for alkaline fuel cells. J. Power Sources, 2009; 187: 39-48. 
208. Drillet, J.F., F. Holzer, T. Kallis, S. Muller, and V.M. Schmidt, Influence of $\mathrm{CO}_{2}$ on the stability of bifunctional oxygen electrodes for rechargeable zinc/air batteries and study of different CO2 filter materials. Phys. Chem. Chem. Phys., 2001; 3: 368-71.

209. Sato, M., M. Ohta, and M. Sakaguchi, Effect of carbon dioxide on electrochemical stability of gas diffusion electrodes in alkaline solution. Electrochim. Acta, 1990; 35: 945-50.

210. Cheng, H.-H. and C.-S. Tan, Reduction of $\mathrm{CO}_{2}$ concentration in a zinc/air battery by absorption in a rotating packed bed. J. Power Sources, 2006; 162: 1431-6.

211. Oy Hydrocell Limited. Air cleaners, carbon-dioxide filters. http://www.hydrocell.fi/en/aircleaners-carbon-dioxide-filters/general-observations/; 2017 [accessed 29.08.17].

212. Fujiwara, N., M. Yao, Z. Siroma, H. Senoh, T. Ioroi, and K. Yasuda, Reversible air electrodes integrated with an anion-exchange membrane for secondary air batteries. J. Power Sources, 2011; 196: 808-13.

213. Dewi, E.L., K. Oyaizu, H. Nishide, and E. Tsuchida, Cationic polysulfonium membrane as separator in zinc-air cell. J. Power Sources, 2003; 115: 149-52.

214. Toussaint, G., P. Stevens, L. Akrour, R. Rouget, and F. Fourgeot, Development of a rechargeable zinc-air battery. ECS Trans., 2010; 28: 25-34.

215. Li, Y., M. Gong, Y. Liang, J. Feng, J.-E. Kim, H. Wang, G. Hong, B. Zhang, and H. Dai, Advanced zinc-air batteries based on high-performance hybrid electrocatalysts. Nat. Commun., 2013; 4: 1-7.

216. Postula, J.J. and R. Thacker, On the use of third electrodes in a secondary zinc-air battery. Energy Conver. Manage, 1970; 10: 45-9.

217. Wang, K., P. Pei, Z. Ma, H. Chen, H. Xu, D. Chen, and H. Xing, Growth of oxygen bubbles during recharge process in zinc-air battery. J. Power Sources, 2015; 296: 40-5.

218. Bockelmann, M., U. Kunz, and T. Turek, Electrically rechargeable zinc-oxygen flow battery with high power density. Electrochem. Commun., 2016; 69: 24-7.

219. Ross, P., A new concept in an electrically rechargeable zinc-air alkaline battery. Lawrence Berkeley National Laboratory. University of California. 2010.

220. Müller, S., O. Haas, C. Schlatter, and C. Comninellis, Development of a $100 \mathrm{~W}$ rechargeable bipolar zinc/oxygen battery. J. Appl. Electrochem., 1998; 28: 305-10.

221. Ma, H., B. Wang, Y. Fan, and W. Hong, Development and characterization of an electrically rechargeable zinc-air battery stack. Energies, 2014; 7: 6549-57.

222. Powerzinc Electric Inc. Powerzinc. http://www.powerzinc.com/; 2017 [accessed 29.08.17].

223. Cooper, J., Powering future vehicles with the refuelable zinc/air battery. LLNL Sci. Technol. Rev., 1995: 7-13.

224. Pei, P., Z. Ma, K. Wang, X. Wang, M. Song, and H. Xu, High performance zinc air fuel cell stack. J. Power Sources, 2014; 249: 13-20. 
225. Mele, C., A. Bilotta, P. Bocchetta, and B. Bozzini, Characterization of the particulate anode of a laboratory flow Zn-air fuel cell. J. Appl. Electrochem., 2017; 47: 877-88.

226. Eos Energy Storage. Eos Technology. http://www.eosenergystorage.com/technology; 2017 [accessed 29.08.17].

227. Amendola, S., M. Binder, P.J. Black, S. Sharp-Goldman, L. Johnson, M. Kunz, et al. Electrically rechargeable, metal-air battery systems and methods. US Patent application 2012/0021303 A1. 2012.

228. Técnicas Reunidas. ZAESS Energy Storage System. http://www.zaess.eu/; 2017 [accessed 29.08.17].

229. Wen, Y.-H., J. Cheng, S.-Q. Ning, and Y.-S. Yang, Preliminary study on zinc-air battery using zinc regeneration electrolysis with propanol oxidation as a counter electrode reaction. J. Power Sources, 2009; 188: 301-7.

230. Schröder, D., T. Arlt, U. Krewer, and I. Manke, Analyzing transport paths in the air electrode of a zinc air battery using X-ray tomography. Electrochem. Commun., 2014; 40: 88-91.

231. Arlt, T., D. Schroder, U. Krewer, and I. Manke, In operando monitoring of the state of charge and species distribution in zinc air batteries using X-ray tomography and model-based simulations. Phys. Chem. Chem. Phys., 2014; 16: 22273-80.

232. Deiss, E., F. Holzer, and O. Haas, Modeling of an electrically rechargeable alkaline Zn-air battery. Electrochim. Acta, 2002; 47: 3995-4010.

233. Coates, D. and A. Charkey, Nickel-zinc batteries in Handbook of Batteries, 3rd Edition, T.B. Reddy D. Linden, Editor., McGraw-Hill; 2002.

234. Ito, Y., M. Nyce, R. Plivelich, M. Klein, and S. Banerjee, Gas evolution in a flow-assisted zinc-nickel oxide battery. J. Power Sources, 2011; 196: 6583-7.

235. Zhangjiagang Chilean electric power storage Fanghua Institute Co., Ltd. Zhangjiagang Smart Grid Fanghua Electrical Energy Storage Research Institute Co. Limited. http://www.zjgzdfh.com/; 2017 [accessed 29.08.17].

236. Li, Z., C. Jie, Y. Yu-sheng, W. Yue-hua, W. Xin-dong, and C. Gao-ping, Study of zinc electrodes for single flow zinc/nickel battery application. J. Power Sources, 2008; 179: 3817.

237. Turney, D.E., M. Shmukler, K. Galloway, M. Klein, Y. Ito, T. Sholklapper, J.W. Gallaway, M. Nyce, and S. Banerhee, Development and testing of an economic grid-scale flow-assisted zinc/nickel-hydroxide alkaline battery. J. Power Sources, 2014; 264: 49-58.

238. Yuanhui, C., X. Xiaoli, L. Dan, L. Xianfeng, L. Qinzhi, and Z. Huamin, Performance and potential problems of high power density zinc-nickel single flow batteries. RSC Adv., 2015; 5: 1772-6. 
239. Spanos, C., D.E. Turney, and V. Fthenakis, Life-cycle analysis of flow-assisted nickel zinc-, manganese dioxide-, and valve-regulated lead-acid batteries designed for demand-charge reduction. Renew. Sustainable Energy Rev., 2015; 43: 478-94.

240. Bass, K., P.J. Mitchell, G.D. Wilcox, and J. Smith, Methods for the reduction of shape change and dendritic growth in zinc-based secondary cells. J. Power Sources, 1991; 35: 333-51.

241. Parker, J.F., I.R. Pala, C.N. Chervin, J.W. Long, and D.R. Rolison, Minimizing shape change at $\mathrm{Zn}$ sponge anodes in rechargeable $\mathrm{Ni}-\mathrm{Zn}$ cells: Impact of electrolyte formulation. J. Electrochem. Soc., 2016; 163: A351-5.

242. Jain, R., T.C. Adler, F.R. McLarnon, and E.J. Cairns, Development of long-lived highperformance zinc-calcium/nickel oxide cells. J. Appl. Electrochem.; 22: 1039-48.

243. Banik, S.J. and R. Akolkar, Suppressing dendritic growth during alkaline zinc electrodeposition using polyethylenimine additive. Electrochim. Acta, 2015; 179: 475-81.

244. Shivkumar, R., G. Paruthimal Kalaignan, and T. Vasudevan, Effect of additives on zinc electrodes in alkaline battery systems. J. Power Sources, 1995; 55: 53-62.

245. Lee, C.W., K. Sathiyanarayanan, S.W. Eom, H.S. Kim, and M.S. Yun, Novel electrochemical behavior of zinc anodes in zinc/air batteries in the presence of additives. J. Power Sources, 2006; 159: 1474-7.

246. Sylla, D., C. Savall, M. Gadouleau, C. Rebere, J. Creus, and P. Refait, Electrodeposition of $\mathrm{Zn}-\mathrm{Mn}$ alloys on steel using an alkaline pyrophosphate-based electrolytic bath. Surf. Coat. Technol., 2005; 200: 2137-45.

247. Pereira, M.S., L.L. Barbosa, C.A.C. Souza, A.C.M. Moraes, and I.A. Carlos, The influence of sorbitol on zinc film deposition, zinc dissolution processand morphology of deposits obtained from alkaline bath. J. Appl. Electrochem., 2006; 36: 727-32.

248. Zhu, J., Y. Zhou, and C. Gao, Influence of surfactants on electrochemical behavior of zinc electrodes in alkaline solution. J. Power Sources, 1998; 72: 231-5.

249. Thornton, R.F. and E.J. Carlson, Properties of alternate electrolytes for secondary zinc batteries. J. Electrochem. Soc., 1980; 127: 1448-52.

250. Adler, T.C., F.R. McLarnon, and E.J. Cairns, Low-zinc-solubility electrolytes for use in zinc/nickel oxide cells. J. Electrochem. Soc., 1993; 140: 289-94.

251. Kwak, B.S., D.Y. Kim, S.S. Park, B.S. Kim, and M. Kang, Implementation of stable electrochemical performance using a $\mathrm{Fe}_{0.01} \mathrm{ZnO}$ anodic material in alkaline $\mathrm{Ni}-\mathrm{Zn}$ redox battery. Chem. Eng. J., 2015; 281: 368-78.

252. Ito, Y., X. Wei, D. Desai, D. Steingart, and S. Banerjee, An indicator of zinc morphology transition in flowing alkaline electrolyte. J. Power Sources, 2012; 211: 119-28.

253. Wei, X., D. Desai, G.G. Yadav, D.E. Turney, A. Couzis, and S. Banerjee, Impact of anode substrates on electrodeposited zinc over cycling in zinc-anode rechargeable alkaline batteries. Electrochim. Acta, 2016; 212: 603-13. 
254. Cheng, Y., H. Zhang, Q. Lai, X. Li, and D. Shi, Performance gains in single flow zinc-nickel batteries through novel cell configuration. Electrochim. Acta, 2013; 105: 618-21.

255. Cheng, Y., H. Zhang, Q. Lai, X. Li, D. Shi, and L. Zhang, A high power density single flow zinc-nickel battery with three-dimensional porous negative electrode. J. Power Sources, 2013; 241: 196-202.

256. Cheng, Y., Q. Lai, X. Li, X. Xi, Q. Zheng, C. Ding, and H. Zhang, Zinc-nickel single flow batteries with improved cycling stability by eliminating zinc accumulation on the negative electrode. Electrochim. Acta, 2014; 145: 109-15.

257. Cheng, Y., H. Zhang, Q. Lai, X. Li, Q. Zheng, X. Xi, and C. Ding, Effect of temperature on the performances and in situ polarization analysis of zinc-nickel single flow batteries. J. Power Sources, 2014; 249: 435-39.

258. Zhang, H., Q. Lai, and Y. Cheng. Zinc-nickel single-fluid cell anode, preparation method of zinc-nickel single-fluid cell anode, and zinc-nickel single-fluid cell. CN Patent 101,299,476. 2014.

259. Zhang, H., Y. Cheng, and Q. Lai. Semi-solid-state zinc nickel flow cell. CN Patent 103,840,187. 2014.

260. He, K., J. Cheng, Y. Wen, W. Cai, and Y. Yang. Study of tubular nickel oxide electrode. In: 2nd International Conference on Machinery, Materials Engineering, Chemical Engineering and Biotechnology (MMECEB). 2015.

261. Yao, S., P. Liao, M. Xiao, J. Cheng, and W. Cai, Study on electrode potential of zinc nickel single-flow battery during charge. Energies, 2017; 10: 1101.

262. Wang, T., A new single flow zinc-nickel hybrid battery using a $\mathrm{Ni}(\mathrm{OH})_{2}-\mathrm{O}_{2}$ composite cathode. Int. J. Electrochem. Sci., 2017; 12: 6022-30.

263. Xiaofeng, L. and G. Yang. A dynamic model of single flow zinc-nickel battery. In: Chinese Automation Congress (CAC). 2015. p. 1328-1332.

264. Li, Y.X., M.C. Wong, W.F. Ip, P.C. Zhao, C.K. Wong, J. Cheng, and Z.-Y. You. Modeling of novel single flow zinc-nickel battery for energy storage system. In: 9th IEEE Conference on Industrial Electronics and Applications. 2014. p. 1621-1626.

265. Li, X., C. Ponce de Léon, F.C. Walsh, R.G.A. Wills, and D. Pletcher, Chapter 8 - Zinc-based flow batteries for medium- and large-scale energy storage in Advances in Batteries for Medium and Large-Scale Energy Storage, Maria Skyllas-Kazacos Chris Menictas, Tuti Mariana Lim, Editor., Woodhead Publishing; 2015. p. 293-315.

266. Kim, J.T. and J. Jorné, The kinetics of a chlorine graphite electrode in the zinc-chlorine battery. J. Electrochem. Soc., 1977; 124: 1473-7.

267. Shenoy, R.V., J.M. Fenton, P. Malachesky, and P. Stonehart, Characterization of a Porous Electrode in a Zinc Chlorine Battery. J. Electrochem. Sci. Technol., 1989; 136: 3181-8. 
268. Kim, J.T. and J. Jorné, Mass transfer of dissolved chlorine to a rotating-zinc hemisphere in ZnCl2 solution. J. Electrochem. Soc., 1978; 125: 89-94.

269. Hart, T.G. Electrode for a zinc-chloride battery and batteries containing the same. US Patent 4,071,660. 1978.

270. Henriksen, G.L. Zinc halogen battery electrolyte composition with lead additive. US Patent 4,306,003. 1981.

271. Hammond, M.J., P.H. Schultz, and V. Feiman. Zinc halogen battery electrolyte compositions with bismuth additive. US Patent 4,307,159. 1981.

272. H., W., S. J.R., and H. R.P., Mass transfer and current distribution in a zinc/redox-battery flow cell. Indian J Technol., 1986; 24: 372-80.

273. M-Z., Y., H. W., and S. J.R., A cycling performance model for the zinc/ferricyanide battery. J. Chem. Ind. Eng. Chi., 1989; 4: 93-114.

274. Assink, R.A. and C. Arnold, Jr. Development of membranes for the zinc/ferricyanide battery. In: 20th Intersoc. Energy Conversion Engineering Conference. 1985.

275. ViZn Energy Inc. Safe energy storage. http://www.viznenergy.com/; 2016 [accessed 29.08.17].

276. Xie, Z., Q. Su, A. Shi, B. Yang, B. Liu, J. Chen, X. Zhou, D. Cai, and L. Yang, High performance of zinc-ferrum redox flow battery with Ac-/HAc buffer solution. J. Energy Chem., 2016; 25: 495-9.

277. Gong, K., X. Ma, K.M. Conforti, K.J. Kuttler, J.B. Grunewald, K.L. Yeager, M.Z. Bazant, S. $\mathrm{Cu}$, and $\mathrm{Y}$. Yan, A zinc-iron redox-flow battery under $\$ 100$ per $\mathrm{kW}$ h of system capital cost. Energy Env. Sci., 2015; 8: 2941-5.

278. Weng, G.-M., Z. Li, G. Cong, Y. Zhou, and Y.-C. Lu, Unlocking the capacity of iodide for high-energy-density zinc/polyiodide and lithium/polyiodide redox flow batteries. Energy Env. Sci., 2017; 10: 735-41.

279. Pan, J., Y. Wen, J. Cheng, J. Pan, S. Bai, and Y. Yang, Evaluation of substrates for zinc negative electrode in acid PbO2-Zn single flow batteries. Chin. J. Chem. Eng., 2016; 24: 52934.

280. Marino, M., L. Misuri, A. Carati, and D. Brogioli, Proof-of-concept of a zinc-silver battery for the extraction of energy from a concentration difference. Energies, 2014; 7: 3664-83.

281. Winsberg, J., S. Muench, T. Hagemann, S. Morgenstern, T. Janoschka, M. Billing, F.H. Schacher, G. Hauffman, J.-F. Gohy, S. Hoeppner, M.D. Hager, and U.S. Schubert, Polymer/zinc hybrid-flow battery using block copolymer micelles featuring a TEMPO corona as catholyte. Polym. Chem., 2016; 7: 1711-8.

282. Winsberg, J., T. Janoschka, S. Morgenstern, T. Hagemann, S. Muench, G. Hauffman, J.-F. Gohy, M.D. Hager, and U.S. Schubert, Poly(TEMPO)/zinc hybrid-flow battery: A novel, "green," high voltage, and safe energy storage system. Adv. Mater., 2016; 28: 2238-43. 
283. Winsberg, J., h. Stolze, A. Schwenke, S. Muench, M.D. Hager, and U.S. Schubert, Aqueous 2,2,6,6-tetramethylpiperidine-N-oxyl catholytes for a high-capacity and high current density oxygen-insensitive hybrid-flow battery. ACS Energy Lett., 2017; 2: 411-6.

284. Hampson, N.A. and A.J.S. McNeil, The electrochemistry of porous zinc V. The cycling behaviour of plain and polymer-bonded porous electrodes in $\mathrm{KOH}$ solutions. J. Power Sources, 1985; 15: 261-85.

285. Shapouri Ghazvini, M., G. Pulletikurthi, Z. Liu, A. Prowald, S. Zein El Abedin, and F. Endres, Electrodeposition and stripping behavior of a zinc/polystyrene composite electrode in an ionic liquid. J. Solid State Electrochem., 2015; 19: 1453-61.

286. Galiński, M., A. Lewandowski, and I. Stępniak, Ionic liquids as electrolytes. Electrochim. Acta, 2006; 51: 5567-80.

287. Keist, J.S., C.A. Orme, P.K. Wright, and J.W. Evans, An in situ AFM study of the evolution of surface roughness for zinc electrodeposition within an imidazolium based ionic liquid electrolyte. Electrochim. Acta, 2015; 152: 161-71.

288. Liu, Z., T. Cui, G. Pulletikurthi, A. Lahiri, T. Carstens, M. Olschewski, and F. Endres, Dendrite-free nanocrystalline zinc electrodeposition from an ionic liquid containing nickel triflate for rechargeable Zn-based batteries. Angew. Chem. Int. Ed. , 2016; 55: 2889-93.

289. Liu, Z., S. Zein El Abedin, and F. Endres, Dissolution of zinc oxide in a protic ionic liquid with the 1-methylimidazolium cation and electrodeposition of zinc from $\mathrm{ZnO} /$ ionic liquid and $\mathrm{ZnO/ionic} \mathrm{liquid-water} \mathrm{mixtures.} \mathrm{Electrochem.} \mathrm{Commun.,} \mathrm{2015;} \mathrm{58:} \mathrm{46-50.}$

290. Xu, J.J., H. Ye, and J. Huang, Novel zinc ion conducting polymer gel electrolytes based on ionic liquids. Electrochem. Commun., 2005; 7: 1309-17.

291. Liu, Z., S. Zein El Abedin, and F. Endres, Electrodeposition and stripping of zinc from an ionic liquid polymer gel electrolyte for rechargeable zinc-based batteries. J. Solid State Electrochem., 2014; 18: 2683-91. 


\section{Figures}

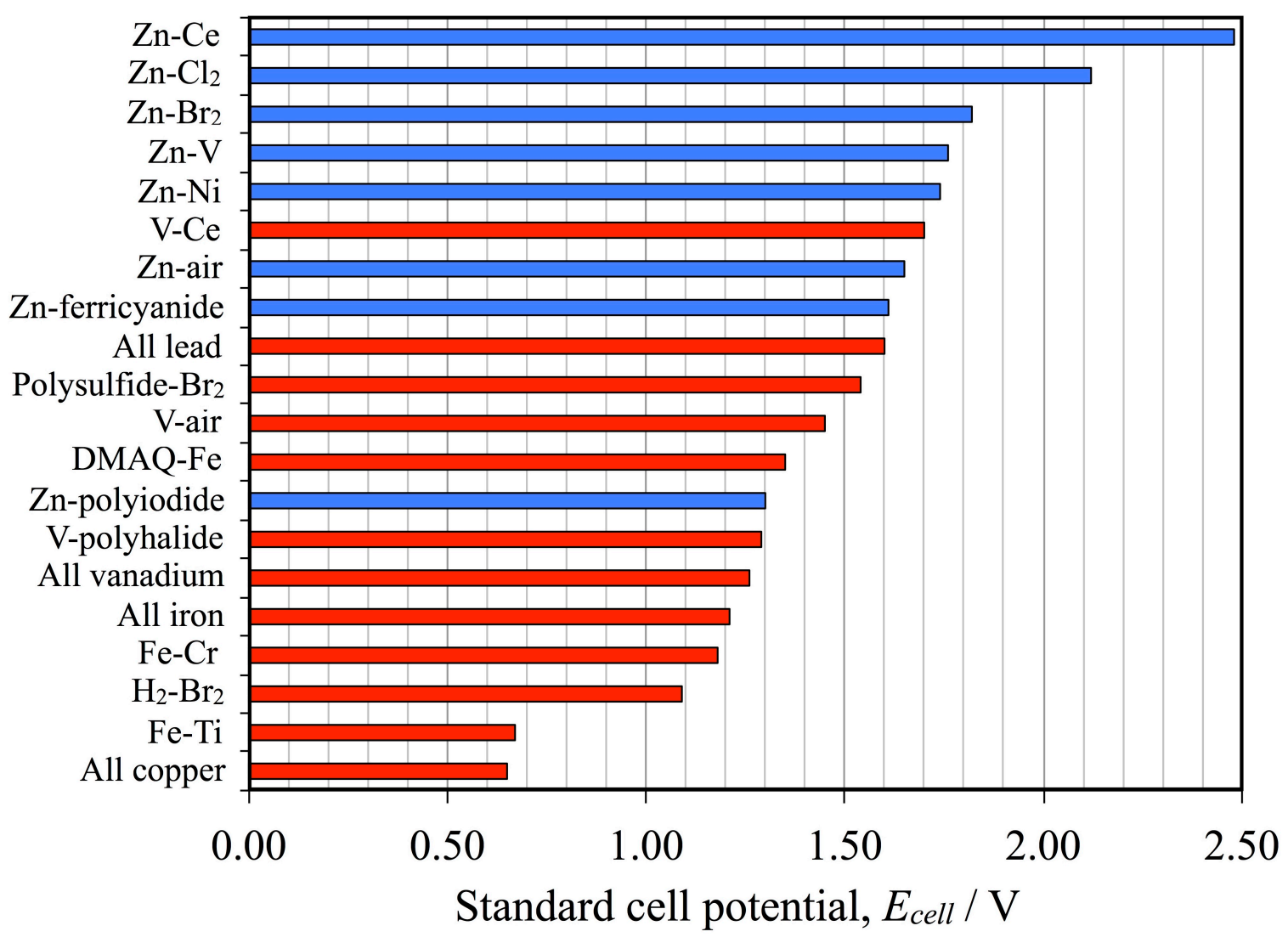

Figure 1. The standard cell potential of selected aqueous redox flow batteries. All-copper [32], Fe-Ti [33], $\mathrm{H}_{2}-\mathrm{Br}_{2}$ [28], Fe-Cr [34], all-iron [35], all-vanadium [36], Vpolyhalide [36], Zn-polyiodide [31], DMAQ-Fe [37], V-O2 [28], polysulfide$\mathrm{Br}_{2}$ [38], all-lead [39], Zn-ferricyanide [29], Zn-air [28], V-Ce [40], Zn-Ni [27], $\mathrm{Zn}-\mathrm{V}$ [26], $\mathrm{Zn}-\mathrm{Br}_{2}$ [25], $\mathrm{Zn}-\mathrm{Cl}_{2}$ [24], and $\mathrm{Zn}-\mathrm{Ce}$ [41]. 


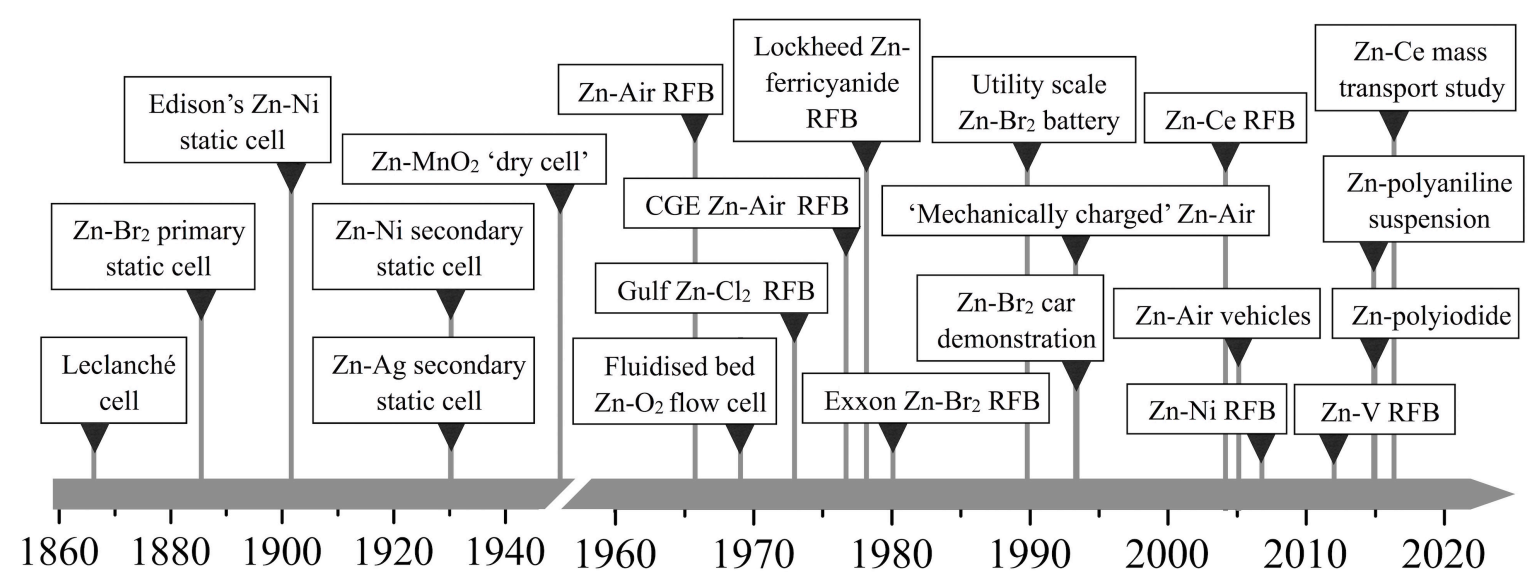

Figure 2. A timeline highlighting selected events during the development of zinc negative rechargeable and flow batteries. Leclanché's $\mathrm{Zn}-\mathrm{MnO}_{2}$ primary static wet cell (1866) [45]; Bradley’s Zn-Br2 primary static cell (1885) [46]; Edison’s Zn-Ni static cell (1901) [47]; Zn-Ni secondary alkaline static cell (1930s) [45]; $\mathrm{Zn}-\mathrm{Ag}$ secondary alkaline static cell (1930s) [45]; $\mathrm{Zn}-\mathrm{MnO}_{2}$ static primary alkaline 'dry cell' (1949) [45]; Zn-air battery with circulating electrolyte (1966) [48]; Fluidised bed $\mathrm{Zn}-\mathrm{O}_{2}$ flow cell (1969) [49]; $\mathrm{Zn}-\mathrm{MnO}_{2}$ secondary static cell

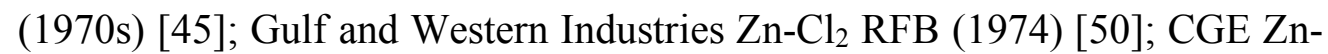
air fuel cell/RFB (1977) [51]; Lockheed Zn-ferricyanide RFB (1978) [29]; Exxon $\mathrm{Zn}-\mathrm{Br}_{2} \mathrm{RFB}$ (1980) [29]; First utility scale $\mathrm{Zn}-\mathrm{Br}_{2}$ battery (Japan) (1990) [52]; SEA Zn-Br 2 car demonstration (1993) [53]; 'Mechanically recharged' Zn-air vehicle batteries (1993) [54]; Patent for the Zn-Ce RFB (2004) [55]; PowerZinc Zn-air vehicles (2005) [56]; Proposal for Zn-Ni RFB (2007) [27]; Proposal for Zn-V RFB (2012) [26]; Patent for Zn-Ni RFB (2012) [57]; Proposal for Zn-polyiodide RFB (2015) [31]; Proposal for Zn-Ag-doped polyaniline suspension RFB (2015) [58]; Mass transport at electrodes for ZnCe RFB (2016) [59]. 


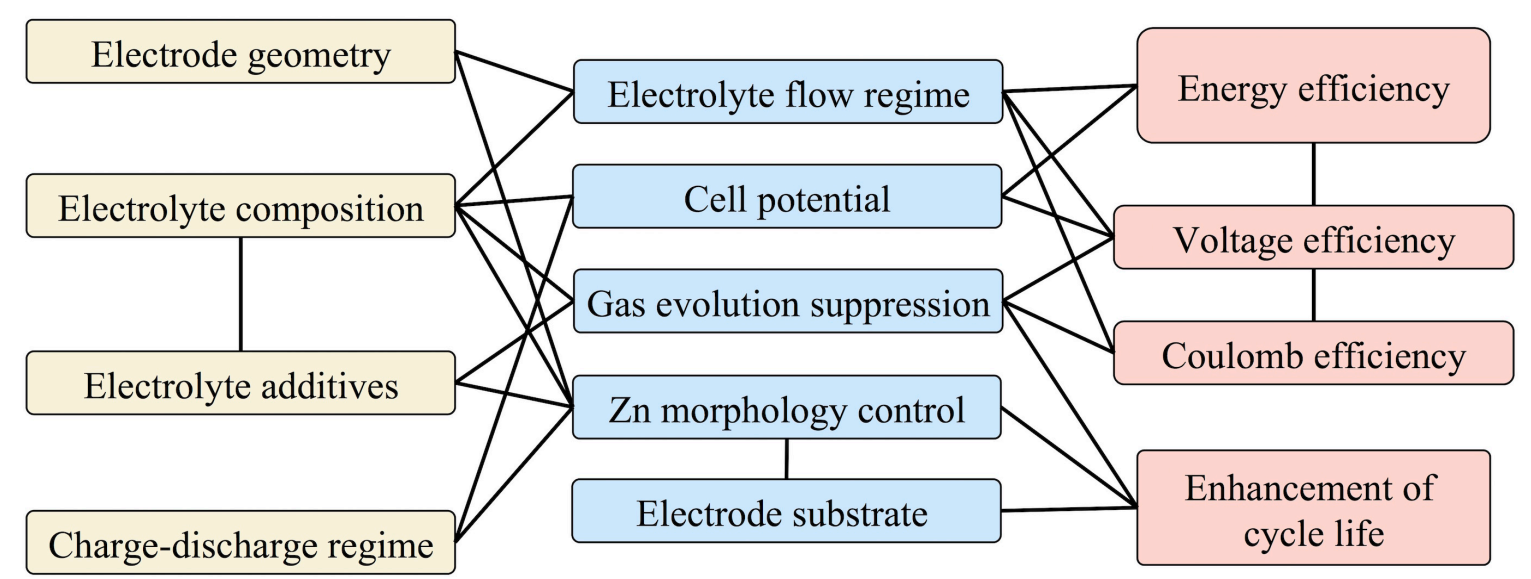

Figure 3. The complex relationship among electrode materials, electrolyte composition, operating conditions and performance in zinc negative flow batteries. 
a)

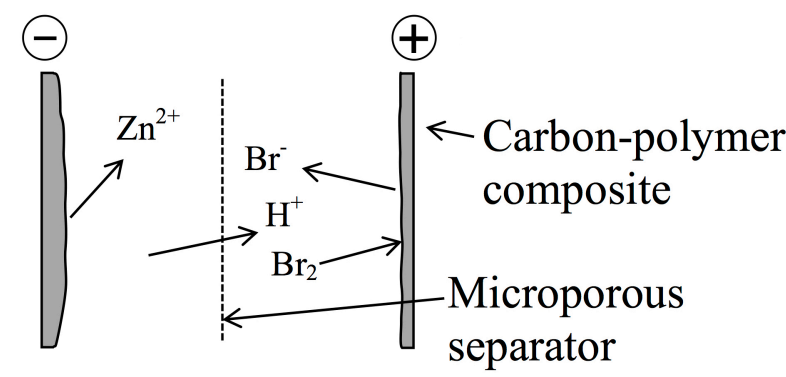

b)

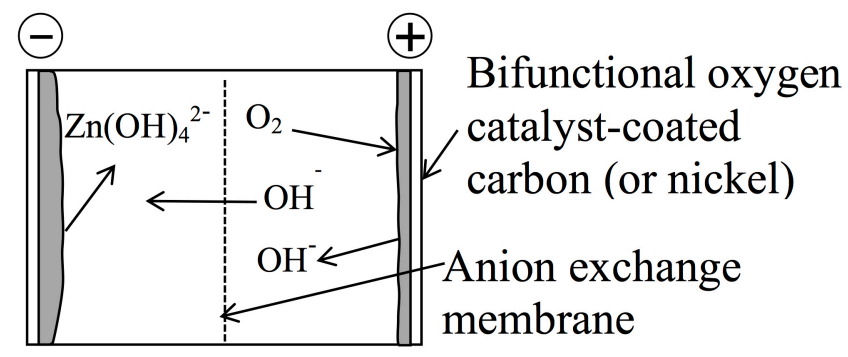

c)

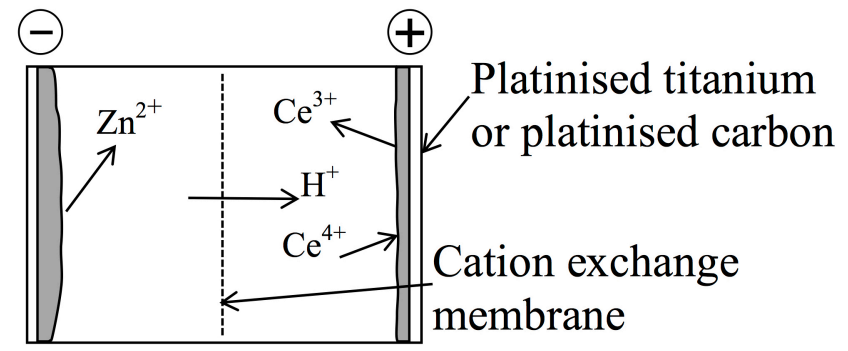

d)

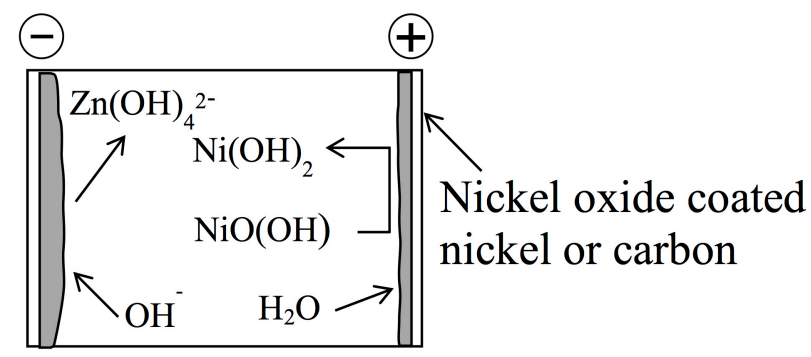

Figure 4. Four types of zinc negative electrode rechargeable flow cells, in which zinc dissolves as ions in the electrolyte, showing the primary discharge processes: a) $\mathrm{Zn}-\mathrm{Br}_{2}$ cell with a cationic membrane, involving reduction of tribromide ions to bromide ions, b) a $\mathrm{Zn}$-air cell with an anionic membrane, involving reduction of oxygen to hydroxyl ions, c) a $\mathrm{Zn}-\mathrm{Ce}$ cell with a cationic membrane, involving reduction of ceric ions to cerous ions and d) an undivided $\mathrm{Zn}-\mathrm{Ni}$ cell, involving reduction of a surface nickel oxide film. 

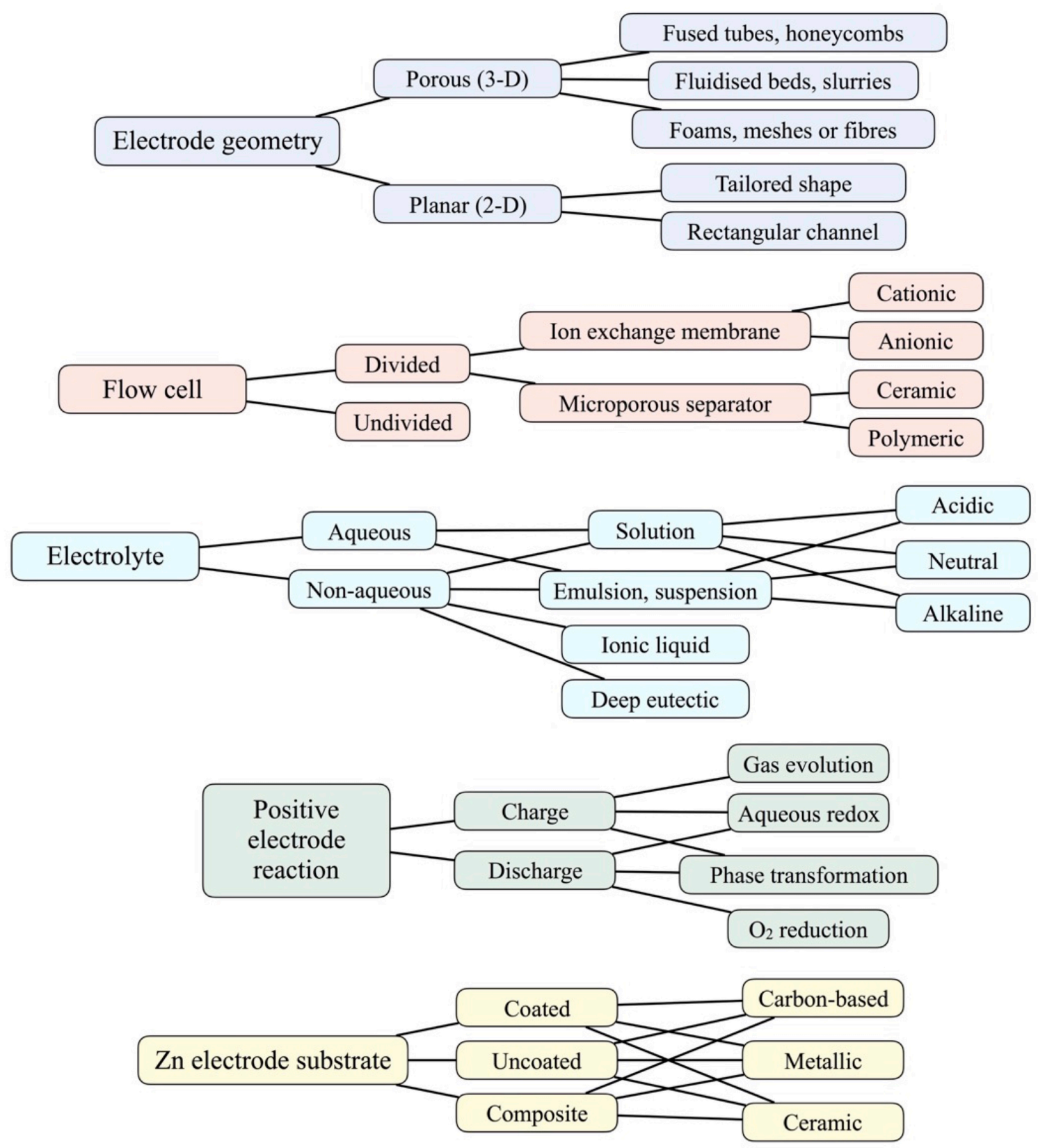

Figure 5. Diagrams illustrating some of the multiple design, material, and operational options in zinc negative flow devices. 

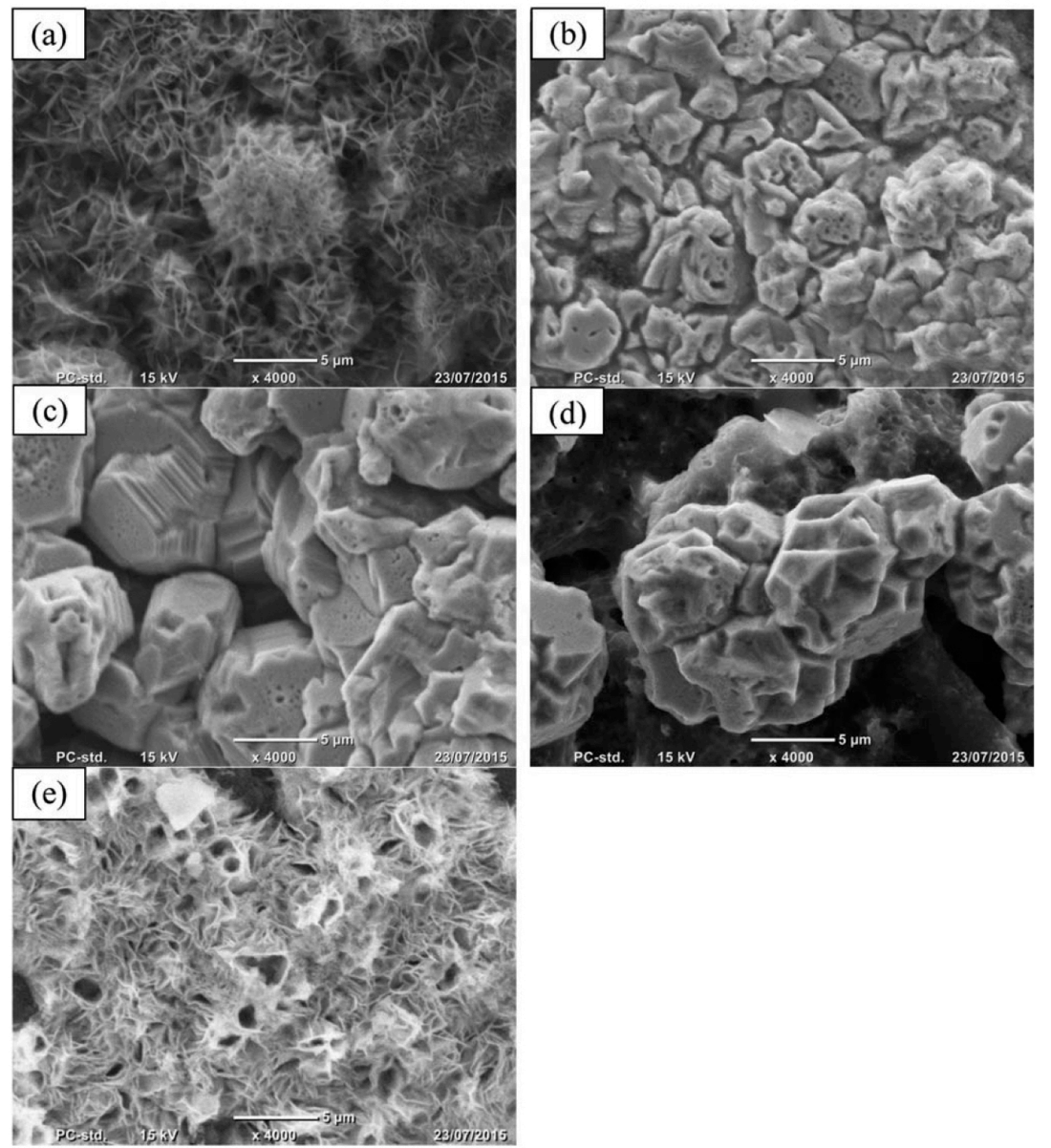

Figure 6. SEM images of $\mathrm{Zn}$ electrodeposits on graphite obtained in diverse supporting electrolytes for $\mathrm{Zn}-\mathrm{Br}_{2}$ RFBs at a current density of $20 \mathrm{~mA} \mathrm{~cm}{ }^{-2}$ over a lapse of 10 min.: a) $\mathrm{Na}_{2} \mathrm{SO}_{4}$, b) $\mathrm{NaBr}$, c) NaCl, d) $\mathrm{NaH}_{2} \mathrm{PO}_{4}$, and e) $\mathrm{NaNO}_{3}$. Reproduced from ref. [86] with permission. 


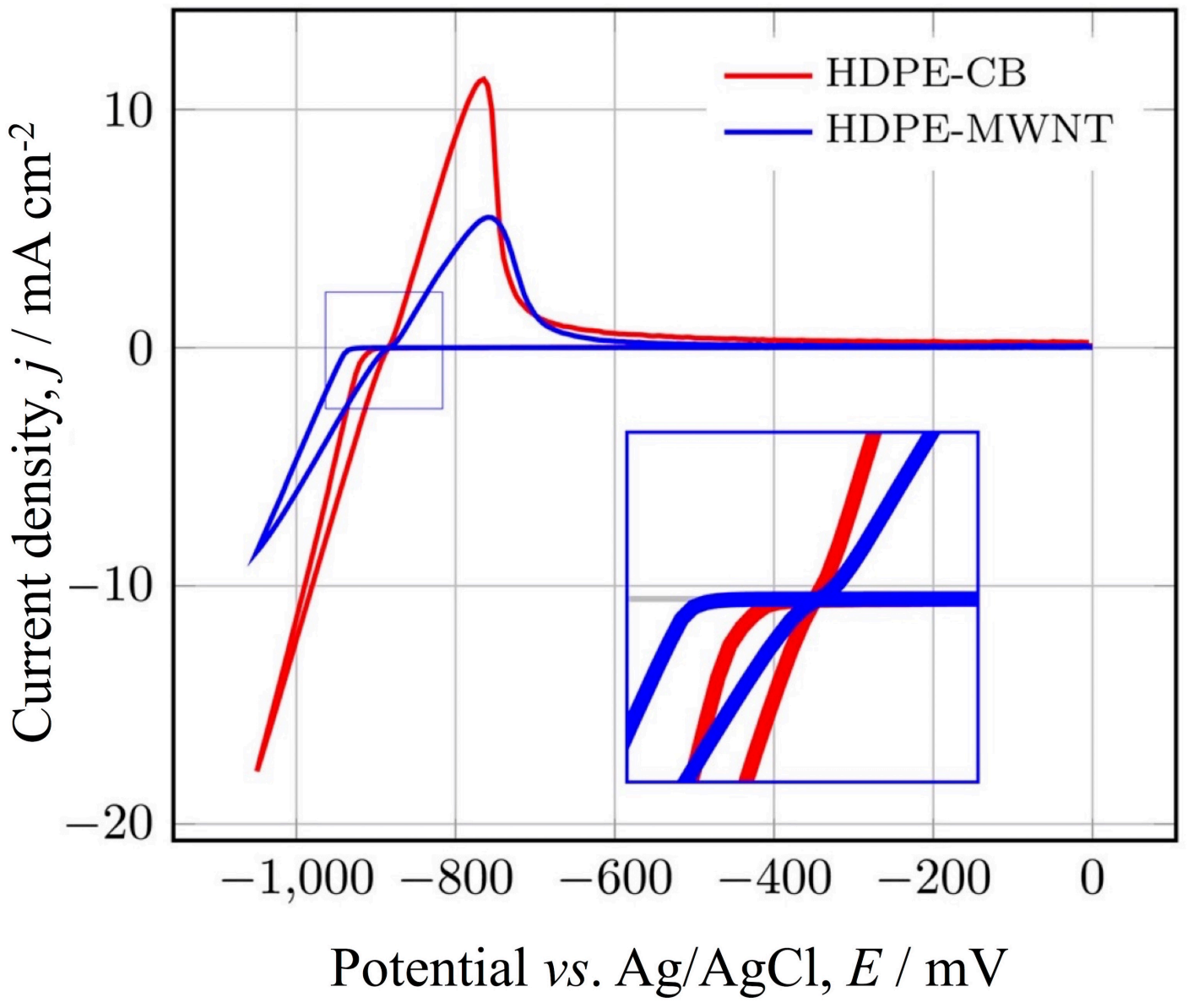

Figure 7. Cyclic voltammogram of $2.25 \mathrm{~mol} \mathrm{dm}^{-3}$ zinc bromide, $0.5 \mathrm{~mol} \mathrm{dm}^{-3}$ zinc chloride and $0.8 \mathrm{~mol} \mathrm{dm}^{-3} \mathrm{~N}$-ethyl-N-methyl pyrrolidinium bromide at a high density polyethylene-carbon black (CB) composite electrode and the same material with a content of $15 \%$ w.t. multiwalled carbon nanotubes (MWCNT). Potential scan rate: $0.1 \mathrm{~V} \mathrm{~s}^{-1}$. Adapted from ref. [69] with permission. 


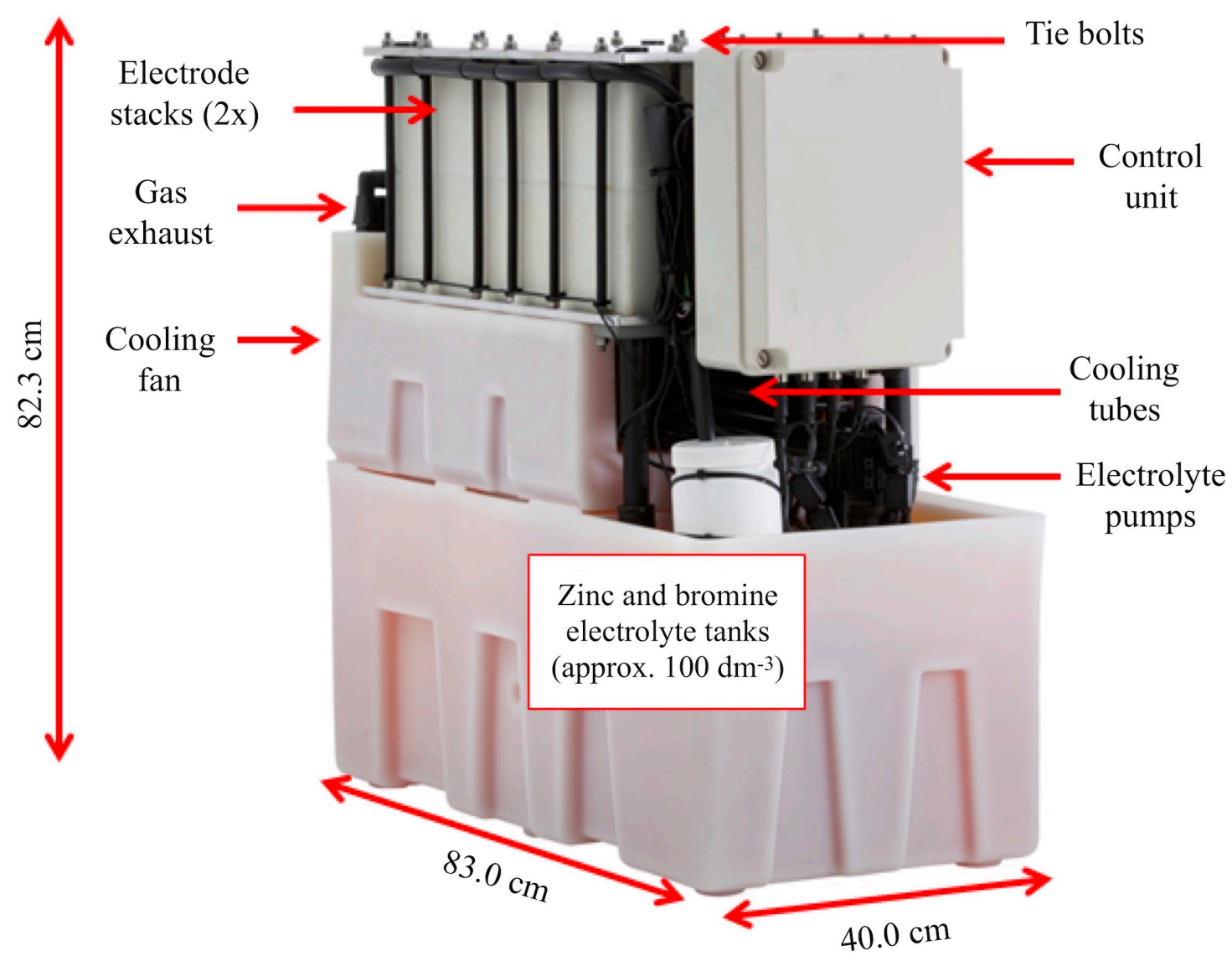

Figure 8. A commercial $\mathrm{Zn}-\mathrm{Br}_{2} \mathrm{RFB}$ showing stack of cells, electrolyte reservoirs, thermal management devices, flow circuits and control system. The device has a maximum capacity of $10 \mathrm{~kW} \mathrm{~h}$, a nominal voltage of $48 \mathrm{~V}$ and a nominal power of $3 \mathrm{~kW}$. The reservoir holds $100 \mathrm{dm}^{-3}$ of electrolyte. Courtesy of Redflow Ltd [114], adapted with permission. 


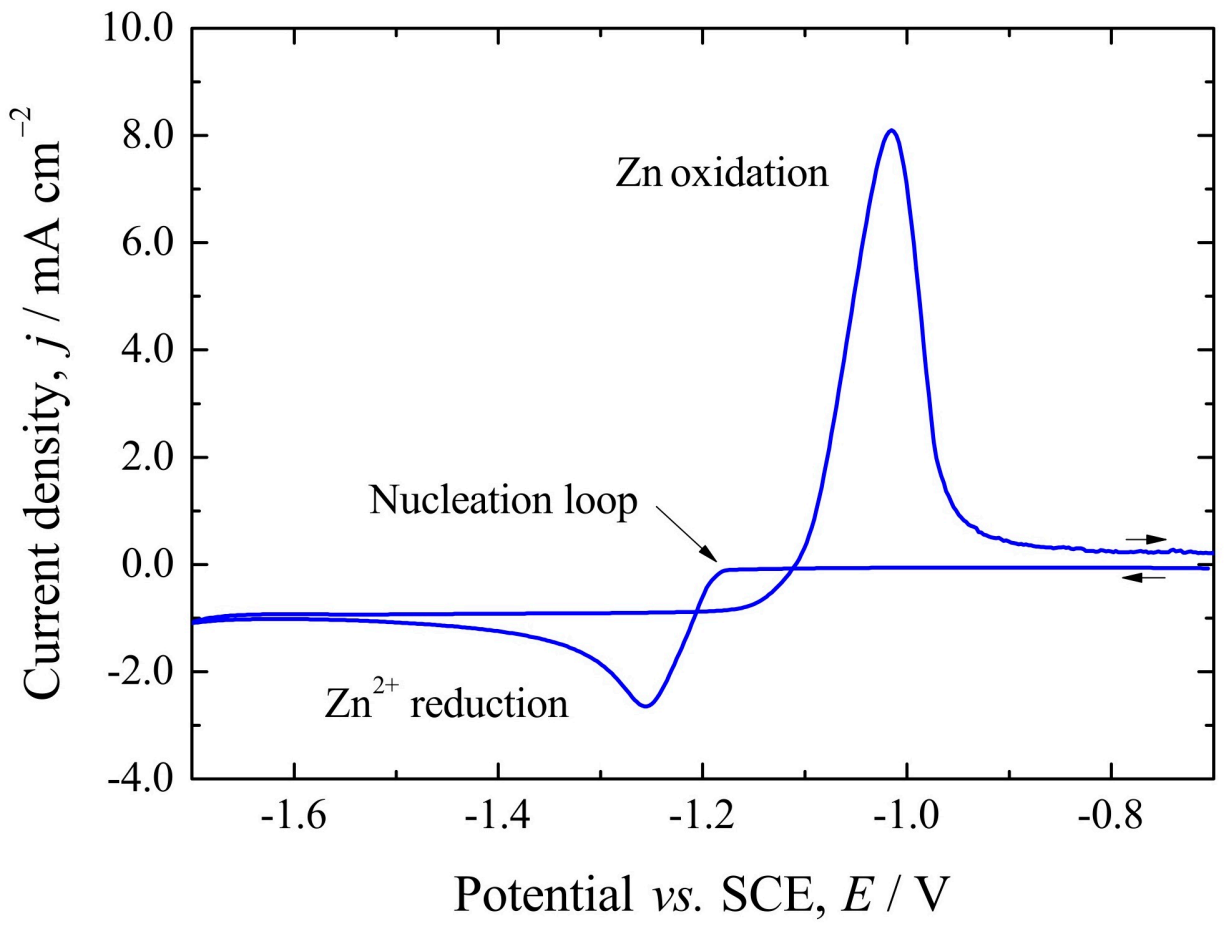

Figure 9. Cyclic voltammogram at a glassy carbon electrode for $10 \mathrm{mmol} \mathrm{dm}^{-3} \mathrm{Zn}(\mathrm{II})$ in $0.5 \mathrm{~mol} \mathrm{dm}^{-3}$ sodium methanesulfonate. Potential sweep rate: $20 \mathrm{mV} \mathrm{s}^{-1}$ at 298 $\mathrm{K}[128]$. 


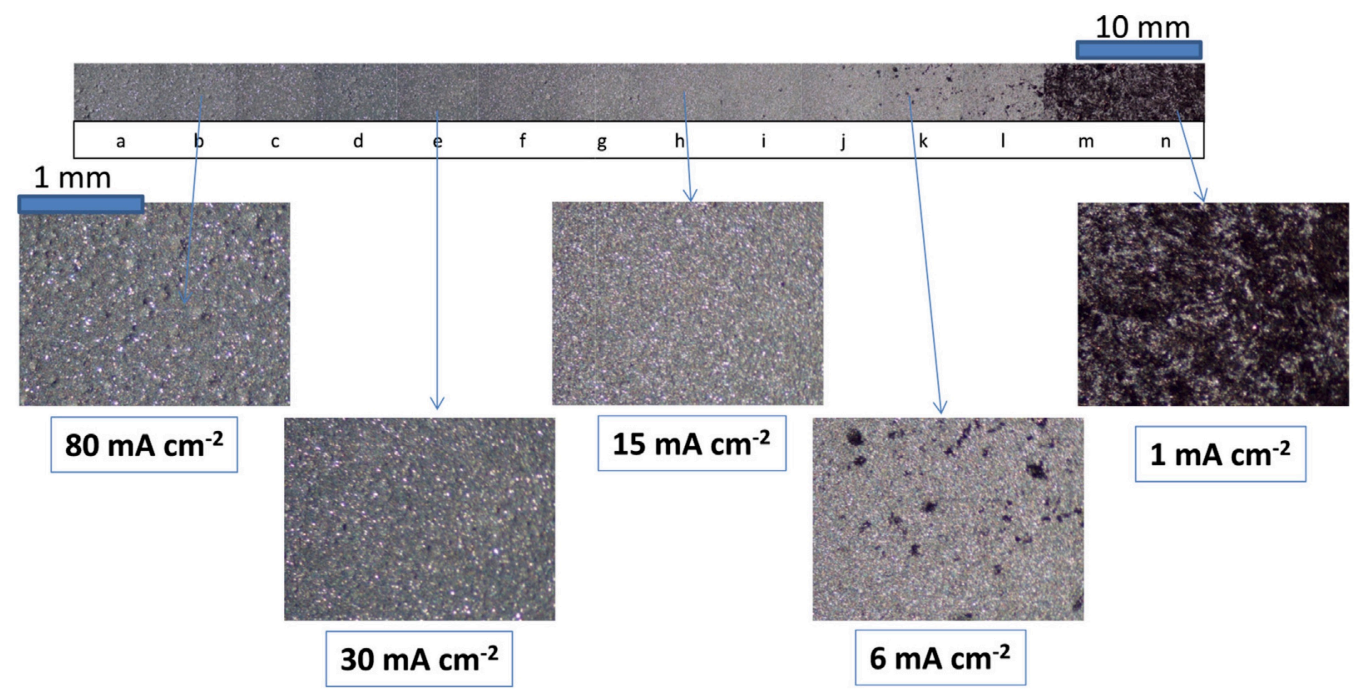

Figure 10. Morphology of $\mathrm{Zn}$ deposits from as a function of current density as studied in a Hull cell. Electrolyte composition was with $2.5 \mathrm{~mol} \mathrm{dm}^{-3} \mathrm{Zn}\left(\mathrm{CH}_{3} \mathrm{SO}_{3}\right)_{2}$ in $1.5 \mathrm{~mol} \mathrm{dm}^{-3} \mathrm{CH}_{3} \mathrm{SO}_{3} \mathrm{H}$ at $314 \mathrm{~K}$. Reproduced from ref. [130] with permission. 


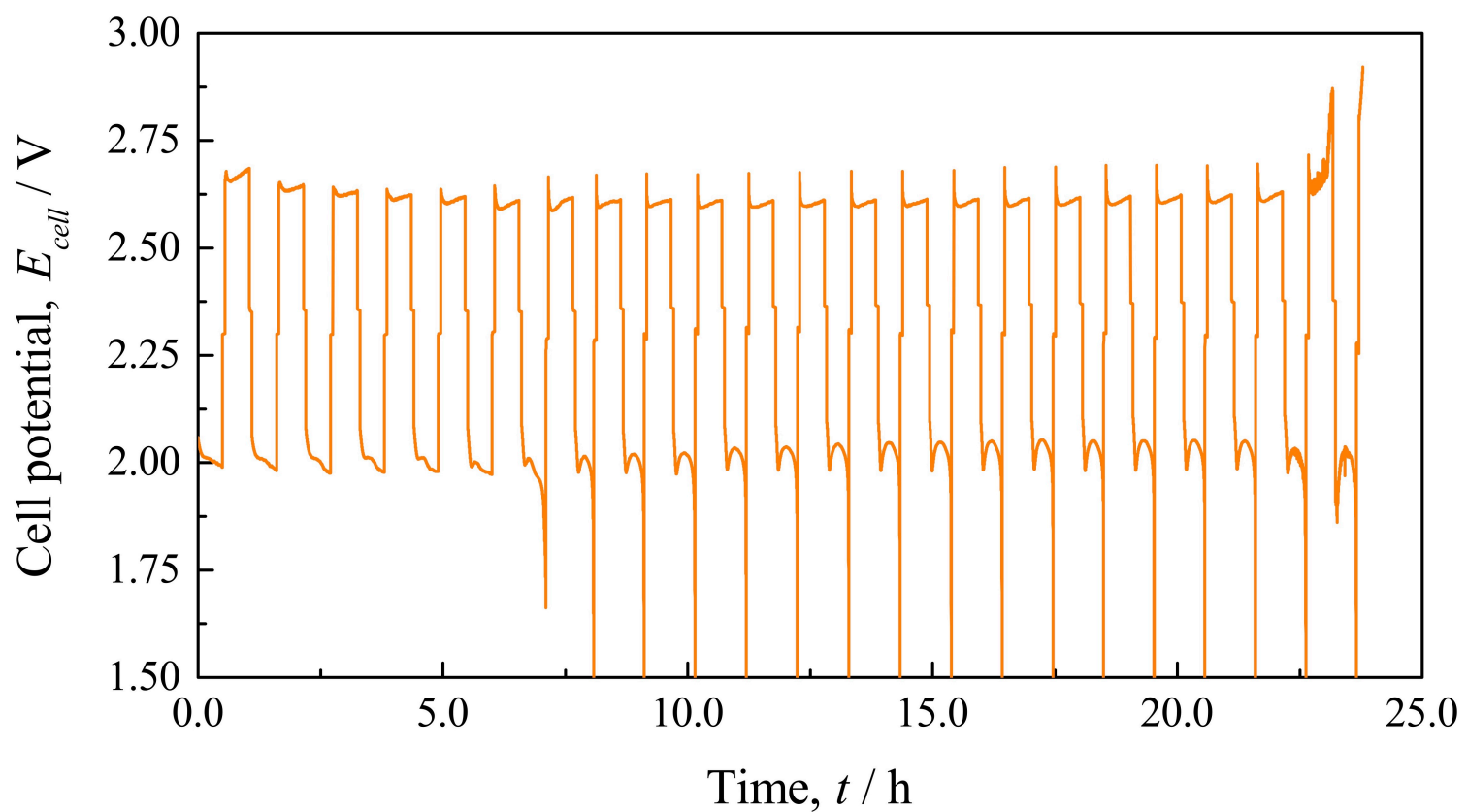

Figure 11. Charge-discharge cell potential of a $\mathrm{Zn}-\mathrm{Ce}$ RFB unit cell using a Pt/Ti felt electrode in constant charge regime at $20 \mathrm{~mA} \mathrm{~cm}^{-2}$ and a mean linear flow rate of $4 \mathrm{~cm} \mathrm{~s}^{-1}$, operating at $50{ }^{\circ} \mathrm{C}$ and starting at $50 \%$ SOC. Positive electrolyte composition: $0.4 \mathrm{~mol} \mathrm{dm}{ }^{-3} \mathrm{Ce}(\mathrm{IV})$ in $4.0 \mathrm{~mol} \mathrm{dm}^{-3} \mathrm{MSA}$; Negative electrolyte composition: $1.5 \mathrm{~mol} \mathrm{dm}^{-3} \mathrm{Ce}(\mathrm{IV})$ in $1.0 \mathrm{~mol} \mathrm{dm}^{-3} \mathrm{MSA}$ [158]. 

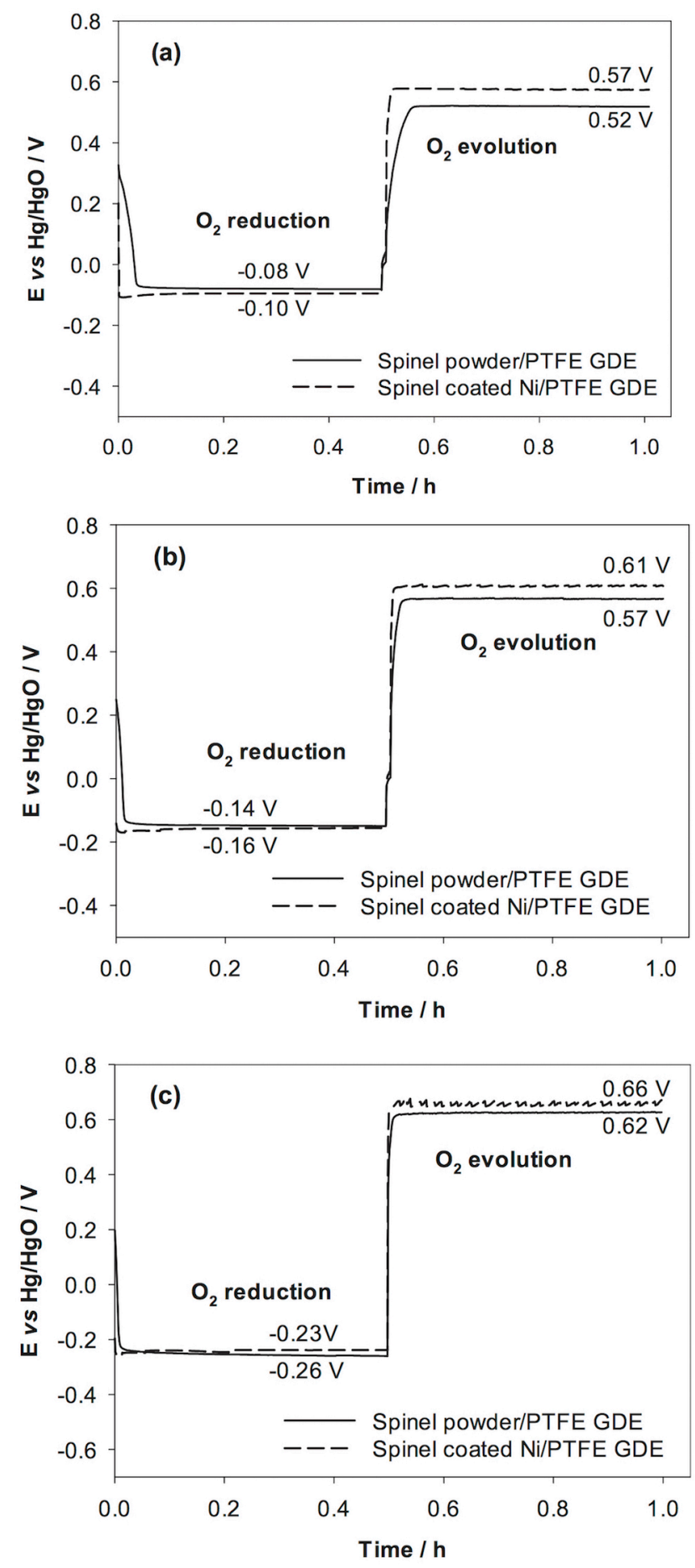

Figure 12. The comparative performance of nickel cobalt oxide spinel catalysed electrodes prepared via the incorporation of spinel powder or via the application of a spinel coating at current densities of a) $20 \mathrm{~mA} \mathrm{~cm}^{-2}$, b) $50 \mathrm{~mA} \mathrm{~cm}{ }^{-2}$, and c) $100 \mathrm{~mA}$ $\mathrm{cm}^{-2}$ in $8 \mathrm{~mol} \mathrm{dm}^{-3} \mathrm{NaOH}$ at $333 \mathrm{~K}$. Reproduced from ref. [204], with permission. 

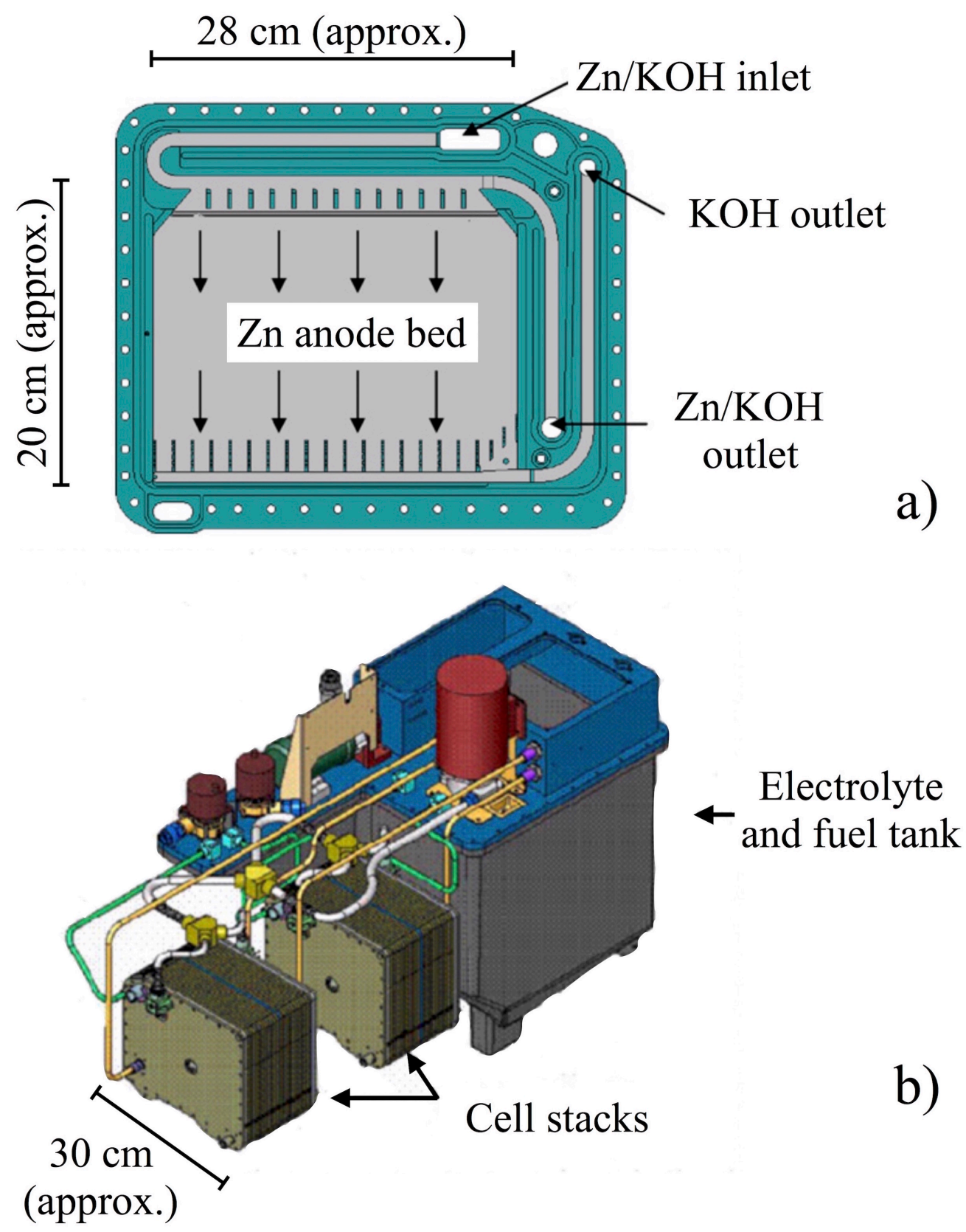

Figure 13. Metallic Power $1.8 \mathrm{~kW} 12$ zinc-air fuel cell stack, 12, $250 \mathrm{dm}^{3}$ capacity electrolyte tank, and zinc discrete particle electrolyser (DPE) and single zinc cell frame showing flow of air, electrolyte and zinc pellets through cell stack. Adapted from ref. [180] with permission. 

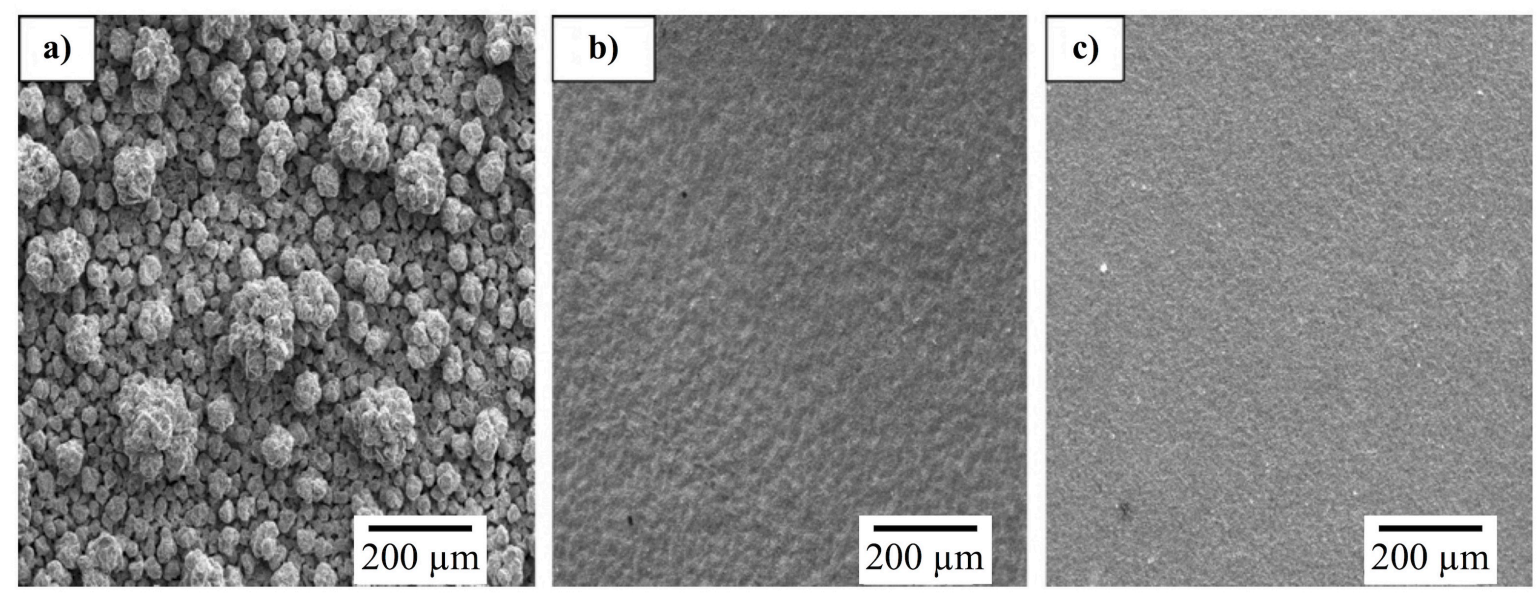

Figure 14. Zinc electrodeposit at $\eta=-100 \mathrm{mV}$ from (a) the blank solution, (b) an alkaline solution containing $10^{-4} \mathrm{M} \mathrm{Pb}$ (II) and (c) an alkaline solution containing $10^{-4} \mathrm{M} \mathrm{Pb}(\mathrm{II})$ and $5 \times 10^{-5} \mathrm{M}$ TBAB. Reproduced from ref. [171] with permission. 

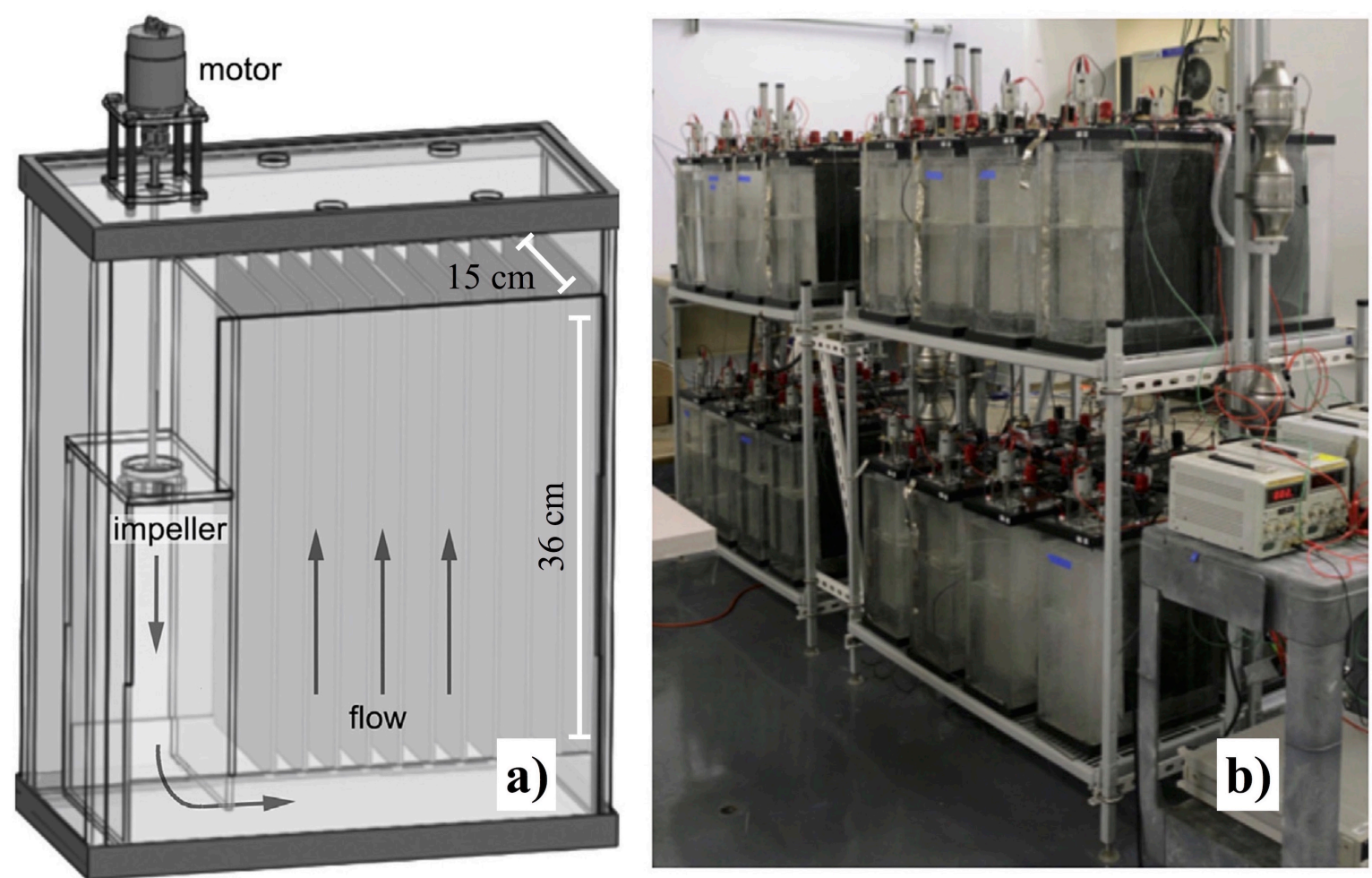

Figure 15. (a) A CAD drawing of the $555 \mathrm{~A}$ h cell; only every eighth electrode plate is shown and a motor is shown coupled to an impeller that maintains electrolyte flowing upward between the electrodes at $0.5 \mathrm{~cm} \mathrm{~s}^{-1}$. (b) A photograph of the completed grid-scale $25 \mathrm{~kW}$ h battery. Adapted from ref. [237] with permission. 

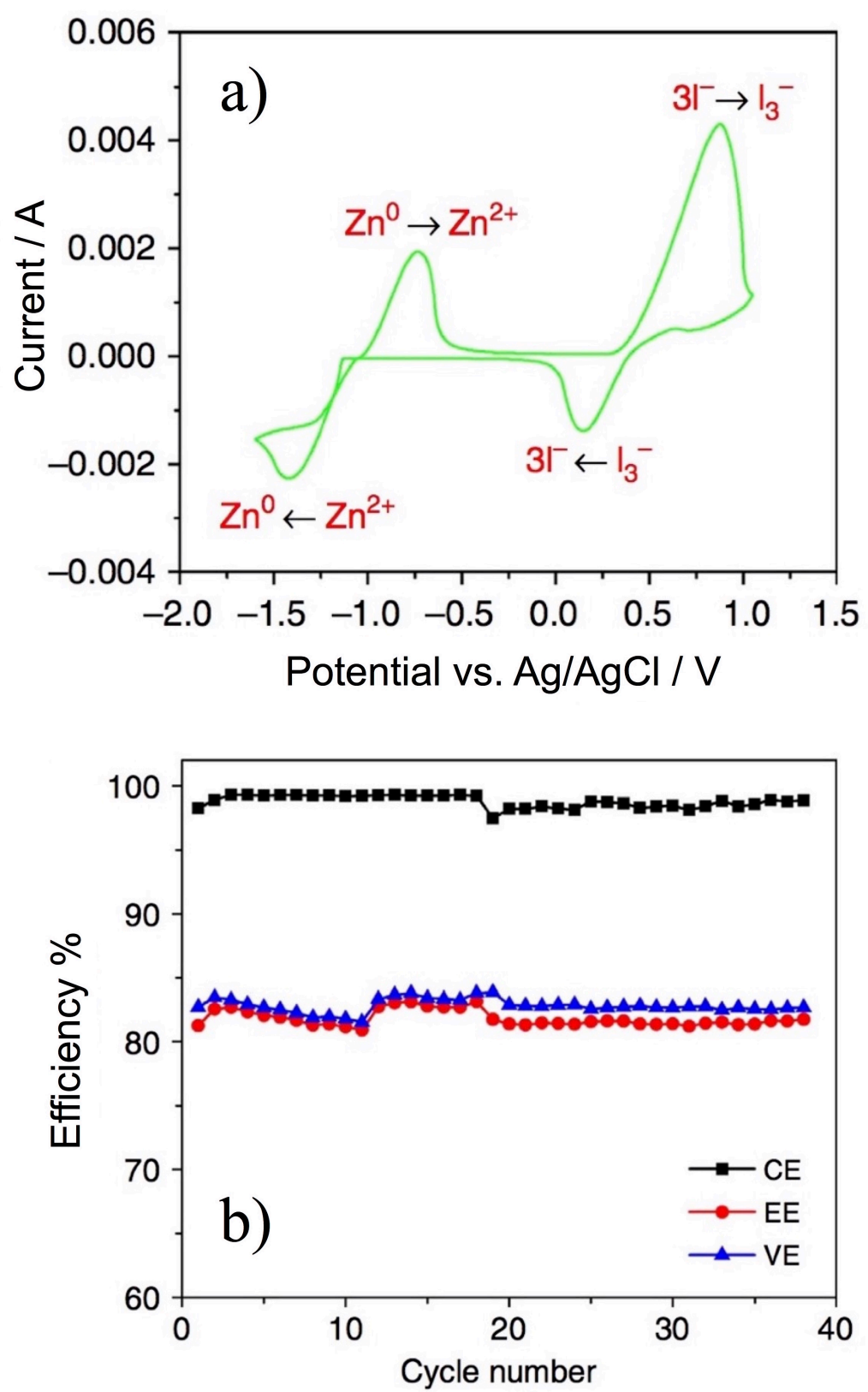

Figure 16. a) Cyclic voltammetry of $0.085 \mathrm{~mol} \mathrm{dm}^{-3} \mathrm{ZnI}_{2}$ on a glassy carbon electrode at a scan rate of $50 \mathrm{mV} \mathrm{s}^{-1}$, b) Cycling efficiency of a divided Zn-polyiodide cell with a $3.5 \mathrm{~mol} \mathrm{dm}^{-3} \mathrm{ZnI}_{2}$ electrolyte at an operational current density of 10 $\mathrm{mA} \mathrm{cm}{ }^{-2}$. Adapted from ref. [31] with permission. 


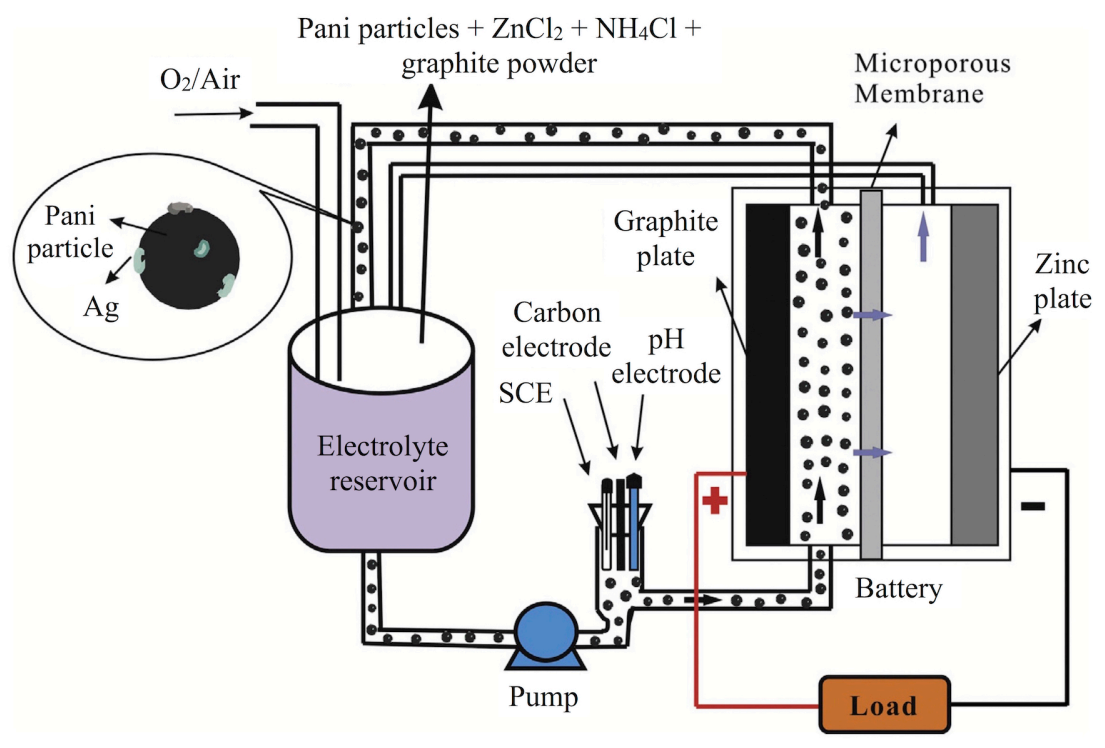

Figure 17. A proposed 'asymmetric' Zn RFB based on an Ag-doped polyaniline (Pani) suspension. Adapted from ref. [58] with permission. 
Table 1. Positive electrode reactions found in zinc-based RFBs and their standard redox potentials.

\begin{tabular}{|c|c|}
\hline Electrode reaction & Standard electrode potential, \\
& $\boldsymbol{E}^{\boldsymbol{o}}$ vs. SHE / V \\
\hline $\mathrm{Ce}^{4+}+\mathrm{e}^{-} \rightleftarrows \mathrm{Ce}^{3+}$ & +1.74 \\
\hline $\mathrm{O}_{2}+4 \mathrm{H}^{+}+4 \mathrm{e}^{-} \rightleftarrows 2 \mathrm{H}_{2} \mathrm{O}$ & +1.23 \\
\hline $\mathrm{Br}_{2}+2 \mathrm{e}^{-} \rightleftarrows 2 \mathrm{Br}^{-}$ & +1.06 \\
\hline $\mathrm{VO}_{2}{ }^{+}+2 \mathrm{H}^{+}+\mathrm{e}^{-} \rightleftarrows \mathrm{VO}^{2+}+\mathrm{H}_{2} \mathrm{O}$ & +1.00 \\
\hline $\mathrm{Fe}^{3+}+\mathrm{e}^{-} \rightleftarrows \mathrm{Fe}^{2+}$ & +0.77 \\
\hline $\mathrm{I}_{3}{ }^{-}+2 \mathrm{e}^{-} \rightleftarrows 3 \mathrm{I}^{-}$ & +0.54 \\
\hline $\mathrm{NiO}(\mathrm{OH})+2 \mathrm{H}_{2} \mathrm{O}+2 \mathrm{e}^{-} \rightleftarrows \mathrm{Ni}(\mathrm{OH})_{2}+2 \mathrm{OH}^{-}$ & +0.49 \\
\hline $\mathrm{O}_{2}+2 \mathrm{H}_{2} \mathrm{O}+4 \mathrm{e}^{-} \rightleftarrows 4 \mathrm{OH}$ & +0.40 \\
\hline $\mathrm{Fe}(\mathrm{CN})_{6}{ }^{3-}+\mathrm{e}^{-} \rightleftarrows \mathrm{Fe}(\mathrm{CN})_{6}{ }^{4-}$ & +0.36 \\
\hline $2 \mathrm{H}^{+}+2 \mathrm{e}^{-} \rightleftarrows \mathrm{H}_{2}$ & 0 \\
\hline
\end{tabular}


Table 2. Selected cell reactions relevant to proposed zinc-based RFBs together with their standard cell potential.

\begin{tabular}{|c|c|c|c|}
\hline Cell type & Discharge cell reaction & $\begin{array}{c}\text { Standard } \\
\text { cell } \\
\text { potential, } \\
E_{\text {cell }}^{o} / \mathbf{V}\end{array}$ & Ref. \\
\hline $\mathrm{Zn}-\mathrm{Ce}$ & $\mathrm{Zn}+2 \mathrm{Ce}^{4+} \rightleftarrows \mathrm{Zn}^{2+}+2 C e^{3+}$ & 2.48 & [23] \\
\hline $\mathrm{Zn}-\mathrm{Cl}_{2}$ & $\mathrm{Zn}+\mathrm{Cl}_{2} \rightleftarrows \mathrm{Zn}^{2+}+2 \mathrm{Cl}^{-}$ & 2.12 & {$[24]$} \\
\hline $\mathrm{Zn}-\mathrm{Br}_{2}$ & $\mathrm{Zn}+\mathrm{Br}_{2} \rightleftarrows \mathrm{Zn}^{2+}+2 \mathrm{Br}^{-}$ & 1.82 & [25] \\
\hline $\mathrm{Zn}-\mathrm{V}$ & $\mathrm{Zn}+2 \mathrm{VO}^{2+} \rightleftarrows \mathrm{Zn}^{2+}+2 \mathrm{VO}_{2}^{+}$ & 1.76 & {$[26,27]$} \\
\hline $\mathrm{Zn}-\mathrm{Ni}$ & $\begin{array}{c}\mathrm{Zn}+\mathrm{Ni}(\mathrm{OH})_{2}+2 \mathrm{OH}^{-} \rightleftarrows \mathrm{NiO}(\mathrm{OH}) \\
+2 \mathrm{H}_{2} \mathrm{O}+\mathrm{Zn}(\mathrm{OH})_{4}^{2-}\end{array}$ & 1.74 & {$[23,27]$} \\
\hline Zn-air & $2 \mathrm{Zn}+\mathrm{O}_{2}+4 \mathrm{OH}^{-} \rightleftarrows 2 \mathrm{Zn}(\mathrm{OH})_{4}^{2-}$ & 1.65 & [28] \\
\hline $\begin{array}{l}\mathrm{Zn-} \\
\text { ferricyanide }\end{array}$ & $\begin{array}{c}\mathrm{Zn}+2 \mathrm{Fe}(\mathrm{CN})_{6}^{3-}+4 \mathrm{OH}^{-} \rightleftarrows \\
2 \mathrm{Fe}(\mathrm{CN})_{6}^{4-}+\mathrm{Zn}(\mathrm{OH})_{4}^{2-}\end{array}$ & 1.61 & [29] \\
\hline $\mathrm{Zn}-\mathrm{Fe}$ & $\mathrm{Zn}+2 \mathrm{Fe}^{3+} \rightleftarrows Z \mathrm{Zn}^{2+}+2 \mathrm{Fe}^{2+}$ & 1.53 & {$[24,30]$} \\
\hline $\begin{array}{c}\text { Zn- } \\
\text { polyiodide }\end{array}$ & $\mathrm{Zn}+\mathrm{I}_{3}^{-} \rightleftarrows \mathrm{Zn}^{2+}+3 I^{-}$ & 1.30 & {$[31]$} \\
\hline
\end{tabular}


Table 3. Average performance comparison of selected zinc half-cell redox flow batteries found in the literature.

\begin{tabular}{|c|c|c|c|c|c|c|c|}
\hline $\begin{array}{c}\text { Zn } \\
\text { RFB }\end{array}$ & $\begin{array}{c}\text { Cell } \\
\text { division }\end{array}$ & $\begin{array}{c}\text { Open- } \\
\text { circuit } \\
\text { cell } \\
\text { potential } \\
\text { / V }\end{array}$ & $\begin{array}{c}\text { Operation } \\
\text { al current } \\
\text { density / } \\
\text { mA cm } \text { cm }^{-2}\end{array}$ & $\begin{array}{c}\% \\
\text { Energy } \\
\text { efficienc } \\
y\end{array}$ & $\begin{array}{c}\% \% \\
\text { Coulombi } \\
\text { c } \\
\text { efficiency }\end{array}$ & $\begin{array}{c}\% \\
\text { Voltage } \\
\text { efficienc } \\
y\end{array}$ & Ref. \\
\hline $\mathrm{Zn}-\mathrm{Ce}$ & $\begin{array}{c}\text { Undivide } \\
\mathrm{d}\end{array}$ & 2.10 & 20 & 75 & 90 & 88 & [60] \\
\hline $\mathrm{Zn}-\mathrm{Ce}$ & Divided & 1.86 & 50 & 43 & 68 & 63 & [41] \\
\hline $\begin{array}{c}\mathrm{Zn}- \\
\text { ferricyanid } \\
\mathrm{e}\end{array}$ & Divided & 1.74 & 35 & 76 & 90 & 84 & $\begin{array}{c}{[29,} \\
60]\end{array}$ \\
\hline $\mathrm{Zn}-\mathrm{Ni}$ & $\begin{array}{c}\text { Undivide } \\
\mathrm{d}\end{array}$ & 1.73 & 10 & 80 & 95 & 88 & $\begin{array}{c}27, \\
61]\end{array}$ \\
\hline $\mathrm{Zn}-\mathrm{V}$ & Divided & 1.70 & 40 & 64 & 96 & 66 & $\begin{array}{l}{[26,} \\
27]\end{array}$ \\
\hline $\mathrm{Zn}-\mathrm{Br}_{2}$ & Divided & 1.67 & 20 & 77 & 79 & 98 & [52] \\
\hline $\mathrm{Zn}-\mathrm{Fe}$ & $\begin{array}{c}\text { Undivide } \\
\mathrm{d}\end{array}$ & 1.53 & 25 & 68 & 85 & 80 & \\
\hline Zn-air & Divided & 1.32 & 20 & 72 & 97 & 74 & [61] \\
\hline $\begin{array}{c}\mathrm{Zn}- \\
\text { polyiodide }\end{array}$ & Divided & 1.26 & 20 & 91 & 99 & 91 & [31] \\
\hline
\end{tabular}


Table 4. Selected electrolyte additives for zinc electrodeposition and inhibition of $\mathrm{H}_{2}$ evolution in acid media.

\begin{tabular}{|l|l|l|l|}
\hline \multicolumn{1}{|c|}{ Additive } & \multicolumn{1}{|c|}{ Electrolyte } & \multicolumn{1}{c|}{ Authors } & \multicolumn{1}{c|}{ Ref. } \\
\hline $\begin{array}{l}\text { 1-butyl-3- } \\
\text { methylimidazolium } \\
\text { ion }\end{array}$ & Acidic sulfate & Zhang et al. & {$[131,132]$} \\
\hline 2-butyne-1,4-diol & Acidic sulfate & Piron et al. & {$[133]$} \\
\hline Benzotriazole & Acidic chloride & Fenelon and Breslin & {$[134]$} \\
\hline CTAB & Acidic sulfate & Tripathy et al. & {$[135]$} \\
\hline Glue & Sulfuric acid & Mackinnon et al. & {$[103]$} \\
\hline Glycerol & Acidic sulfate & Oliveira and Carlos & {$[136]$} \\
\hline Gum Arabic & Sulfuric acid & Sato & {$[137]$} \\
\hline Indium(III) ion & Sulfuric acid & Yano et al. & {$[138]$} \\
\hline Lead(II) ion & Acidic sulfate & Ichino et al. & {$[139]$} \\
\hline $\begin{array}{l}\text { Nonyl- } \\
\text { phenoloxyethylene }\end{array}$ & Sulfuric acid & Hosny & {$[140]$} \\
\hline $\begin{array}{l}\text { Perfluorinated } \\
\text { organics }\end{array}$ & Acidic sulfate & $\begin{array}{l}\text { Cachet } \text { et al. and } \\
\text { Tripathy } \text { et al. }\end{array}$ & {$[141,142]$} \\
\hline Phosphonium salts & Acidic chloride & Troquet and Pagetti & {$[143]$} \\
\hline Sodium lauryl sulfate & Acidic sulfate & Tripathy et al. & {$[144]$} \\
\hline TBAB & Acidic sulfate & Tripathy et al. & {$[135]$} \\
\hline Thiourea & Acidic chloride & Mouanga et al. & {$[145]$} \\
\hline
\end{tabular}


Table 5. Selected electrolyte additives for electrodeposition and dissolution of zinc in alkaline media.

\begin{tabular}{|c|c|c|c|}
\hline Additive & Electrolyte & Authors & Ref. \\
\hline Calcium hydroxide & $\begin{array}{l}\text { Potassium } \\
\text { hydroxide }\end{array}$ & Jain et $a l$. & {$[242]$} \\
\hline Polyethylenimine & $\begin{array}{l}\text { Potassium } \\
\text { hydroxide }\end{array}$ & $\begin{array}{l}\text { Banik and } \\
\text { Akolkar }\end{array}$ & {$[243]$} \\
\hline Thiourea & $\begin{array}{l}\text { Potassium } \\
\text { hydroxide }\end{array}$ & Shivkumar et al. & {$[244]$} \\
\hline Furfuraldehydethiosemicarbazone & Sodium hydroxide & Kavitha et al. & {$[172]$} \\
\hline Citric acid & $\begin{array}{l}\text { Potassium } \\
\text { hydroxide }\end{array}$ & Lee et al. & {$[245]$} \\
\hline Tartaric acid & $\begin{array}{l}\text { Potassium } \\
\text { hydroxide }\end{array}$ & Lee et al. & {$[245]$} \\
\hline Succinic acid & $\begin{array}{l}\text { Potassium } \\
\text { hydroxide }\end{array}$ & Lee et al. & {$[245]$} \\
\hline Cellulose & $\begin{array}{l}\text { Potassium } \\
\text { hydroxide }\end{array}$ & Lee et al. & {$[176]$} \\
\hline Polyvinylalcohol & $\begin{array}{l}\text { Sodium hydroxide/ } \\
\text { sodium chloride }\end{array}$ & $\begin{array}{l}\text { Ortiz-Aparicio et } \\
\text { al. }\end{array}$ & {$[169]$} \\
\hline Hydroxylamine & $\begin{array}{l}\text { Alkaline phosphate/ } \\
\text { sulfate }\end{array}$ & Sylla et al. & {$[246]$} \\
\hline Sorbitol & $\begin{array}{l}\text { Sodium hydroxide/ } \\
\text { sodium sulfate }\end{array}$ & Pereira et al. & {$[247]$} \\
\hline CTAB & $\begin{array}{l}\text { Potassium } \\
\text { hydroxide }\end{array}$ & Zhu et al. & {$[248]$} \\
\hline
\end{tabular}

